\title{
Distribution and Habitat Use of Benthic Fishes in the lower Kanawha River, West Virginia
}

\author{
Nathaniel V. Owens \\ West Virginia University, nvowens@mix.wvu.edu
}

Follow this and additional works at: https://researchrepository.wvu.edu/etd

Part of the Aquaculture and Fisheries Commons, Biodiversity Commons, Terrestrial and Aquatic Ecology Commons, and the Zoology Commons

\section{Recommended Citation}

Owens, Nathaniel V., "Distribution and Habitat Use of Benthic Fishes in the lower Kanawha River, West Virginia" (2019). Graduate Theses, Dissertations, and Problem Reports. 4116.

https://researchrepository.wvu.edu/etd/4116

This Thesis is protected by copyright and/or related rights. It has been brought to you by the The Research Repository @ WVU with permission from the rights-holder(s). You are free to use this Thesis in any way that is permitted by the copyright and related rights legislation that applies to your use. For other uses you must obtain permission from the rights-holder(s) directly, unless additional rights are indicated by a Creative Commons license in the record and/ or on the work itself. This Thesis has been accepted for inclusion in WVU Graduate Theses, Dissertations, and Problem Reports collection by an authorized administrator of The Research Repository @ WVU. For more information, please contact researchrepository@mail.wvu.edu. 


\title{
DISTRIBUTION AND HABITAT USE OF BENTHIC FISHES IN THE LOWER KANAWHA RIVER, WEST VIRGINIA
}

\author{
Nathaniel Owens \\ Thesis submitted to the \\ Davis College of Agriculture, Natural Resources, and Design \\ At West Virginia University
}

In partial fulfillment of the requirements for the degree of

Master of Science in

Wildlife and Fisheries Resources

Stuart A. Welsh, Ph.D., Chair

Quinton E. Phelps, Ph. D.

Daniel A. Cincotta, M.S.

Division of Forestry and Natural Resources

Morgantown, WV

2019

Keywords: trawling, benthic, large river, darters, Ammocrypta, Percina, Etheostoma, distribution, gear bias, undiscovered populations, habitat use, occupancy, Kanawha River, West Virginia, Siamese trawl, Missouri-Mini trawl

Copyright 2019 Nathaniel Owens 


\title{
ABSTRACT \\ Distribution and habitat use of benthic fishes in the \\ lower Kanawha River, West Virginia.
}

\begin{abstract}
Nathaniel Owens
The Kanawha River in West Virginia is a historically diverse system in terms of ichthyofauna although like many other large rivers, it has been subjected to a suite of anthropomorphic perturbations. These include this system being modified to allow the passage of commercial vessels for industry thus altering flow regimes, increased sedimentation, water depth, and channelization, and decreased interactions with its floodplain. Additionally, the fishes of this system have suffered from deleterious historical water quality issues caused by intensive timber operations, mining, and industrial waste. Post Clean Air Act, Clean Water Act, and Surface Mining Control and Reclamation Act water quality has substantially improved and assessments of pelagic fishes within this system indicate that they have responded positively. However, due to sampling bias with traditional collection techniques the WVDNR was data deficient on benthic fishes within this nonwadeable system. This study successfully detected seven species that were previously undetected from the Kanawha River proper by implementing benthic otter trawling with the Gerken Siamese Trawl (Innovative Net Systems). In addition to expanding the known distributions of many of West Virginia's benthic fishes within the Kanawha River proper this study was also able to elucidate associations between several benthic fishes and their habitat use in large rivers, indicating that islands may be providing "islands" of habitat that are important to benthic fishes in this system and that physical habitat is likely more influential to benthic fishes' habitat use than water quality.
\end{abstract}




\section{ACKNOWLEDGMENTS}

\section{To Dan Cincotta,}

I would like to thank you for always being supportive of my professional goals and providing guidance to me when I need it most. I am very lucky to have you as a mentor and even luckier to have you as a friend. If it were not for you I do not know how I would have gotten through this endeavor. You were gracious enough to open your home to me whenever I needed it, both in Morgantown and in Elkins. You fostering me as a young biologist will always be remembered. I will always keep fond memories of the comical conversations we have shared. Thank you for always reminding me to "stay out of the weeds".

To Dr. Stuart Welsh,

I would like to thank you firstly for being my major professor and allowing me to do this project under you. Secondly, your guidance pertaining to school and the editing of this document has been thoroughly appreciated. Thirdly, thank you for allowing me to come to your office so frequently to discuss aspects of this project and other things that weren't quite as pertinent. Lastly, but certainly, not least I would like to express my gratitude for asking me how was doing, offering to lend me a hand when I may have needed it, and sharing some laughter and sometimes tears with me in your office when reminiscing. For this, I am most grateful.

To Dr. Quinton Phelps,

I would like to thank you for all of your input towards this project and advice with benthic trawling techniques. More importantly, I would like you to know that I am very thankful for you sharing some of your life experiences with me when I needed them. Your inquiries as to how I was feeling were always well received and will definitely be remembered. Thank you.

To my technicians,

I am extremely thankful for your help in the completion of this project. Chris Smith, Maddie Cogar, Kyle Matt, Paul Robért, and Davey O'kernick thank you for all of the long hours and hard work put in on the trawl boat and the hours spent in the laboratory. I also appreciate you guys and gals having some fun while "giving it the business" making this project very enjoyable.

To my family,

Thank you for all of your support on so many different levels. Without being able to call you guys when I needed it I do not know if I could have completed my graduate endeavors. I am very thankful to have all of you in my life and with any luck, I will have a bit more time visit with school out of the way.

To my friends both new and old,

I would like to thank all of the friends that I have had throughout my graduate career. I have had many changes occur during the last three years and without the strong support of my friends I do not know what I would have done without you. 


\section{Dedication}

Isaac Gibson, you are a true biologist and one of the most wonderful people I have ever had the privilege of knowing. I will be forever grateful for being able to share such unique and fun experiences with you while in the field. I always enjoyed our crazy conversations while driving across the state. You were a true naturalist in every sense of the word. Every trip afield I hear your voice and imagine the things we would do or talk about. Whether it be shocking a riffle for Candy Darters, "coming back for you" in the New River or exploring the amenities at Mountain Quest Institute.

I always will remember the good times we shared. 


\section{TABLE OF CONTENTS}

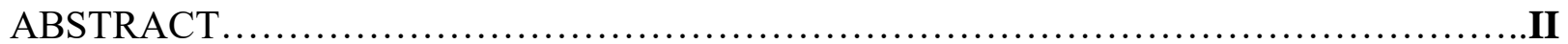

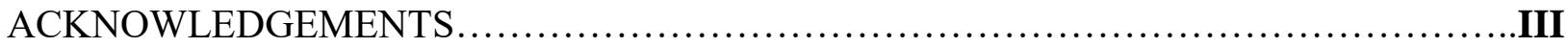

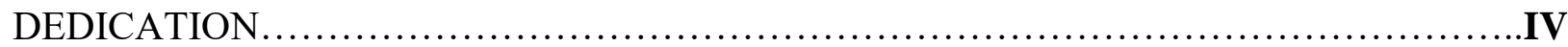

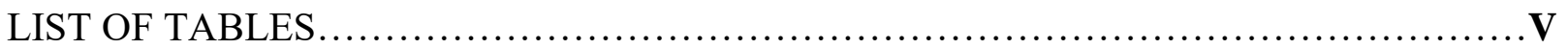

LIST OF FIGURES ....................................................................

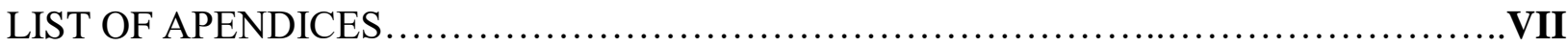

Chapter 1: Introduction and Literature Review..........................................

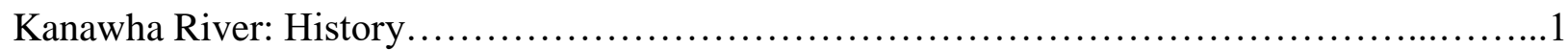

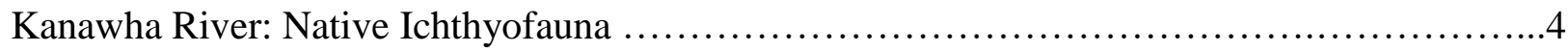

Kanawha River: Historic Sampling .....................................................

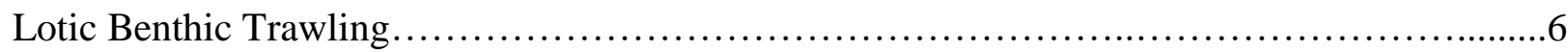

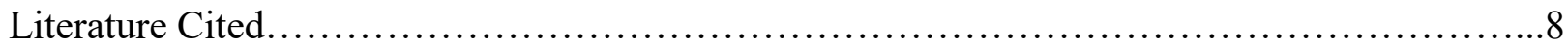

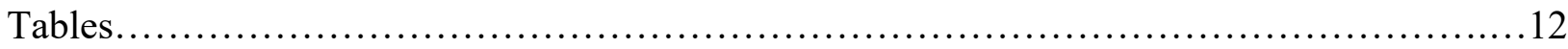

Chapter 2: Distribution and Habitat use of benthic fishes in the Kanawha River, West

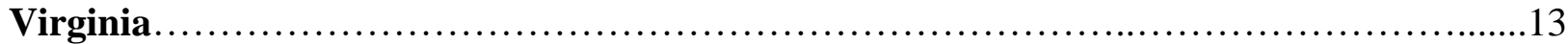

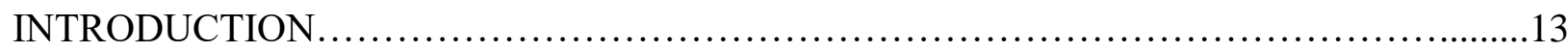

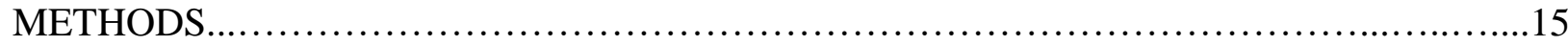

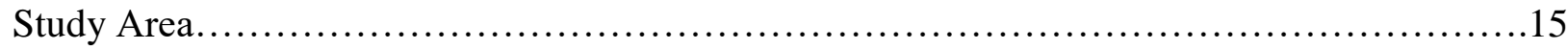

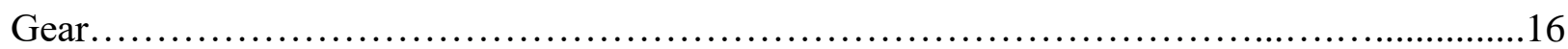

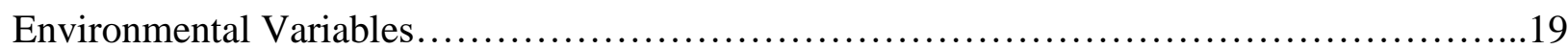

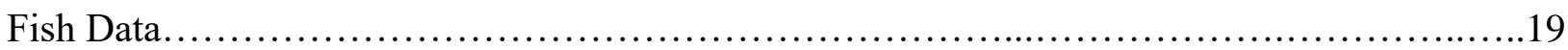

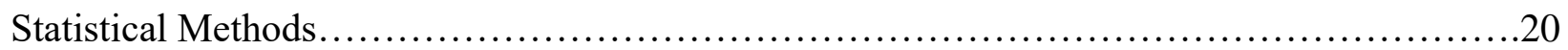

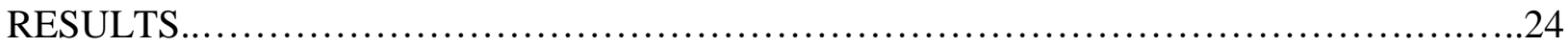

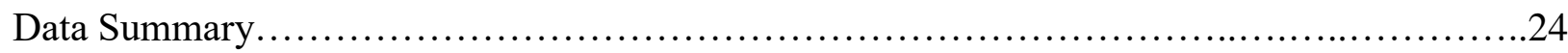

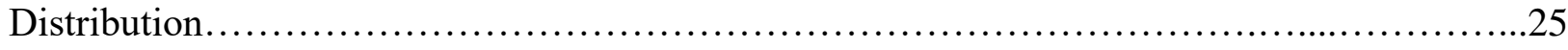

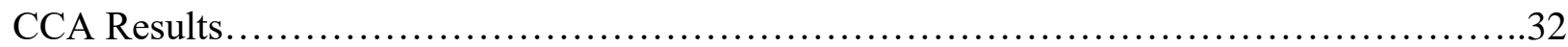

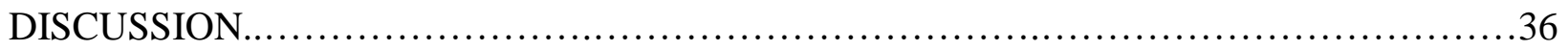


LITERATURE CITED.

Chapter 2: Distribution and Habitat use of benthic fishes in the Kanawha River, West Virginia. Continued

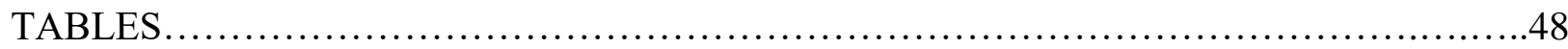

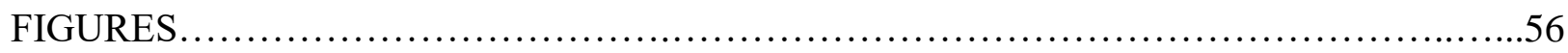

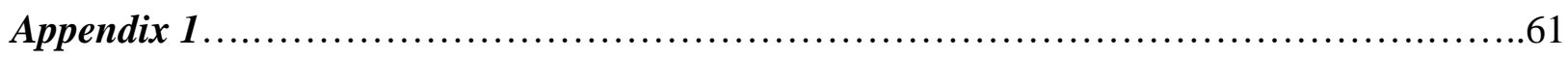

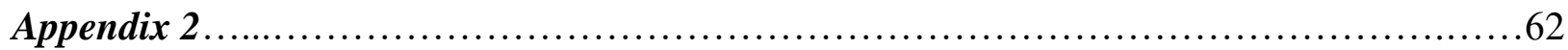

\section{LIST OF TABLES}

\section{Chapter 1}

Table 1. List of benthic SGCN fishes potentially distributed in the Kanawha River proper..... 12

\section{Chapter 2}

Table 1: Table containing the sampling locale names, respective pools, counties, and UTM coordinates of approximate centers of the area where sampling was conducted ...............48

Table 1: Table containing habitat names, codes, and descriptions sampled...................48

Table 3: Table consisting of the environmental covariates collected for each sample (i.e.,

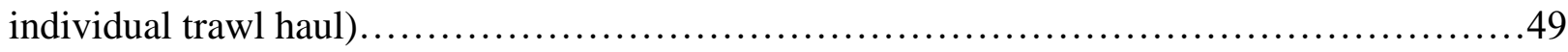

Table 4: Table containing the size classes used for substrate classification...................49

Table 5: Table containing mean covariate values and standard deviations (i.e., mean $( \pm \mathrm{SD})$ ) by

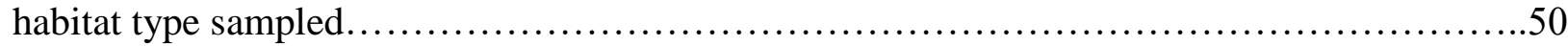

Table 6: Table listing the names, total abundance, and SGCN status of the species of observed

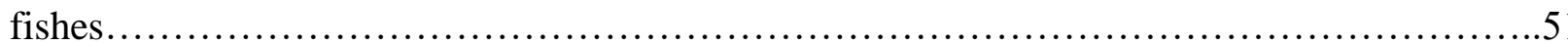

Table 7: Benthic SGCNs that were confirmed to be occupying the navigable Kanawha River....

Table 8 : Species collected representing new distribution and species richness records for the Kanawha River. 
Table 9: Candidate environmental predictor variables used in forward model selection

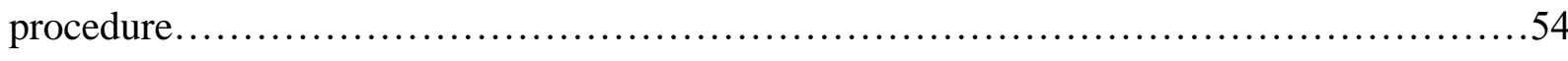

Table 10: Table containing the species names and species code used in CCA analysis. Codes

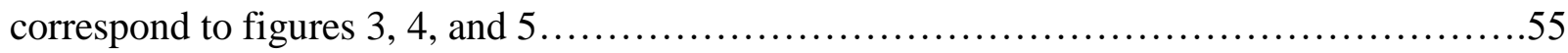

\section{LIST OF FIGURES}

\section{Chapter 1}

\section{Chapter 2}

Figure 1: Map depicting the study area (Kanawha River) with sampling locales labeled 1-9 from Table 1 (e.g., 1. Tenmile Creek, 2. Hurricane Creek / Buffalo Creek, 3. Pocatalico River, 4. Coal River, 5. Blaine Island, 6. Elk River, 7. Scotts Island, 8. Watsons Island, and 9. Wheeler

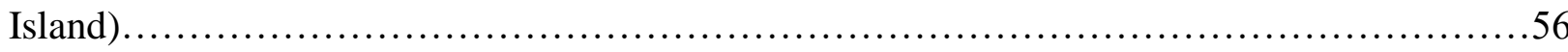

Figure 2: Map of various habitats sampled consisting of: 1. Main Channel (MC), 2. Main Channel Border (MCB), 3. Island Main Channel Border, 4. Island Head (IH), 5. Island Toe (IT), 6. Island Side Channel Border (ISCB), 7. Side Channel, 8. Island Side Channel Border (ISCB), and 9. Tributary (TRIB). Corresponding written description listed in table $2 \ldots \ldots \ldots \ldots \ldots \ldots \ldots . \ldots 5$

Figure 3: CCA ordination of fish species in constrained variable space displayed with axis 1 vs 2

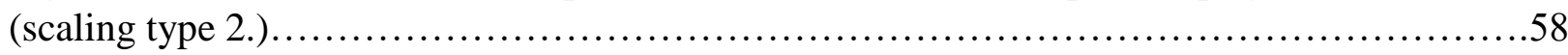

Figure 4: CCA ordination of fish species in constrained environmental variable space displayed

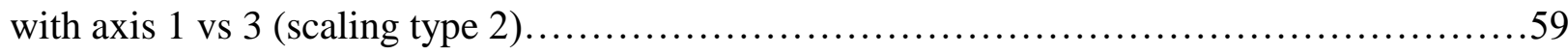

Figure 5: CCA ordination of fish species in constrained environmental variable space displayed

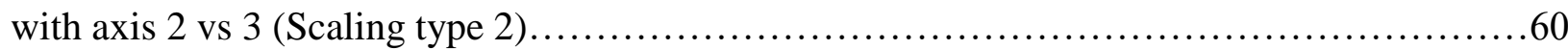

\section{LIST OF APENDICES}

\section{Appendix 1}

Tables

Table 1: Table containing the species for which Kanawha River distributions are provided in Appendix 1 (Figures 1-20) and whether they are a species of greatest need status (SGCN).....61

\section{Appendix 2}

\section{Figures}

Figure 1: Distribution of the Streamline Chub (Erimystax dissimilis) in the Kanawha River, West Virginia 
Figure 2: Distribution of the Bigeye Chub (Hybopsis amblops) in the Kanawha River, West

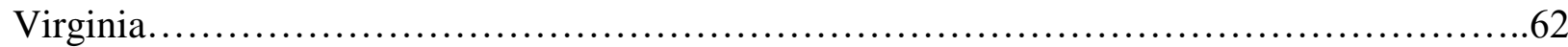

Figure 3: Distribution of the Shoal Chub (Macrhybopsis hyostoma) in the Kanawha River, West

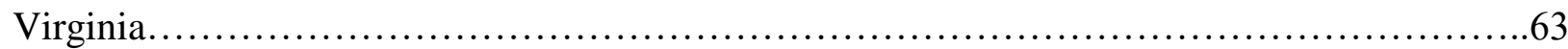

Figure 4:Distribution of the Silver Chub (Macrhybopsis storeriana) in the Kanawha River, West Virginia 63

Figure 5: Distribution of the Ghost Shiner (Notropis buchanani) in the Kanawha River, West Virginia.

Figure 6: Distribution of the Bullhead Minnow (Pimephales vigilax) in the Kanawha River, West Virginia.... .64

Figure 7:Distribution of the Blue Catfish (Ictalurus furcatus) in the Kanawha River, West Virginia. .65

Figure 8:Distribution of the Channel Catfish (Ictalurus punctatus) in the Kanawha River, West

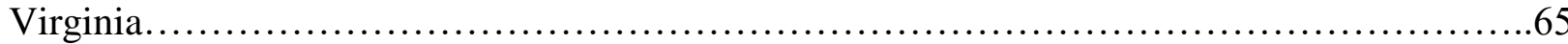

Figure 9: Distribution of the Orangespotted Sunfish (Lepomis humilis) in the Kanawha River,

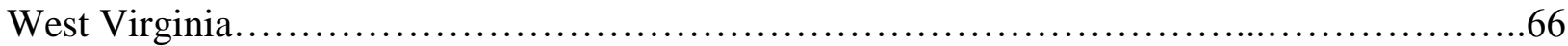

Figure 20: Distribution of then Northern Madtom (Noturus stigmosus) in the Kanawha River, West Virginia......................................................................66

Figure 11: Distribution of the Western Sand Darter (Ammocrypta clara) in the Kanawha River, West Virginia.

Figure 12: Distribution of the Eastern Sand Darter (Ammocrypta pellucida) in the Kanawha River, West Virginia.

Figure 13: Distribution of the Bluebreast Darter (Etheostoma camurum) in the Kanawha River, West Virginia..............................................................68

Figure 14: Distribution of the Tippecanoe Darter (Etheostoma tippecanoe) in the Kanawha River, West Virginia........................................................68

Figure 15: Distribution of the Channel Darter (Percina copelandi) in the Kanawha River, West Virginia.

Figure 16: Distribution of the Gilt Darter (Percina evides) in the Kanawha River, West Virginia.

Figure 17: Distribution of then Longhead Darter (Percina macrocephala) in the Kanawha River, West Virginia................................................................70

Figure 18: Distribution of then Slenderhead Darter (Percina phoxocephala) in the Kanawha River, West Virginia..........................................................70 
Figure 19: Distribution of the Dusky Darter (Percina sciera) in the Kanawha River, West

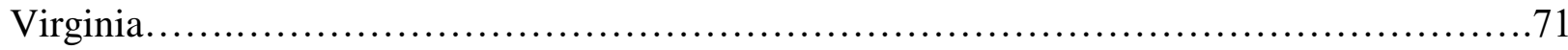

Figure 20: Distributing of the River Darter (Percina shumardi) in the Kanawha River, West

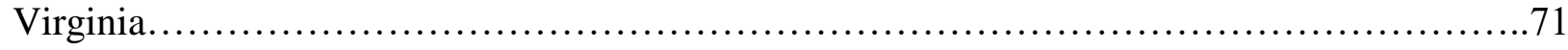




\section{Chapter 1: Introduction and Literature Review}

\section{Kanawha River: History}

The Kanawha River, a $6^{\text {th }}$ order and $4^{\text {th }}$ largest tributary to the Ohio River located in south-central West Virginia, is formed by the confluence of the New and Gauley rivers in Gauley Bridge, WV. This formation of the Kanawha River proper is just 2.2 rkm upstream of Kanawha Falls near Glen Ferris, WV in Fayette County. The Kanawha River intersects four counties (Fayette, Kanawha, Putnam, and Mason) as it flows north-west before its confluence with the Ohio River in Point Pleasant, WV. The Kanawha River drains an area of 31,660 $\mathrm{km}^{2}\left(12,244 \mathrm{mi}^{2}\right)$ (Messenger 1997) as its tributaries cut through the Allegheny Mountains (e.g., New River) from its headwaters in North Carolina and cascade off the Appalachian Plateau (e.g., Gauley River) (Addair 1944). This system is a part of one of the oldest watersheds in the world as the New River was part of the prehistoric Teays River the only river to cut through the Appalachian Mountains. The ancient Teays was able to maintain its course through the uplifting that occurred during the Appalachian orogeny approximately 750-270 million years ago (Hocutt et al. 1986).

The now dead Teays River used to drain the valleys that are now filled by the Kanawha River and the New River until it reaches the Nitro area. The present-day Kanawha River departs from prehistoric Teays channel after stream piracy by the Pocatalico River diverting it northward to its present terminus in Point Pleasant (Hocutt et al. 1986; Hansen 1987). Before Pleistocene glaciation occurred and the creation of Teays Lake the ancient Teays River also drained part of the modern-day Ohio system as it drained northwestward towards present-day Columbus Ohio including the Marietta, Vernon, Newark, old Big Sandy, old licking, and old Kentucky Rivers until it met up with the old Mississippi River (Tight 1903; Ray 1974; Hocutt et al., 1986; Hansen 1987). 
In addition to the Kanawha River having a rich drainage history it also has a long history of anthropogenic perturbations. Navigation of this system began in the later part of the 1700s. After George Washington returned from his second trans-Allegheny tour in 1784 he suggested that it would be of vast commercial and political importance to make the Kanawha River navigable (Kemp 2000). At the time salt production was the largest industry in the Kanawha River valley. Crudely constructed wooden boats loaded with salt were floated downstream on a one-way trip from just above Charleston to the Ohio River. The boats were disassembled upon reaching their destination because it was too difficult to get them back upstream. Later that same year Washington became one of the founders of what would eventually become the James River Company (Kemp 2000).

Between the years 1820-1835, the James River Company began diverting water via wing dikes and excavating the channel to at least a $1 \mathrm{~m}$ depth. The U.S. Army Corps of Engineers (USACE) completed the construction of 10 low lift wicket dams in 1898. This allowed the lower $47 \mathrm{rkm}$ of the river to be navigated via slackwater (Kemp 2000). Later in the 1930's the now aging low lift dams were replaced with four high lift dams (i.e., Robert C. Byrd, Winfield, Marmet, and London Lock and Dams) that maintain a 2.74 m (9') pool depth (Kemp 2000). In 1979 the locks of these installations were widened allowing for larger barges and increased traffic frequency (Kemp 2000; Bjorgo 2006). This increase of water levels and channelization altered the Kanawha River's floodplain connection, natural flow regimes, and bottom substrates (Nielsen et al. 1986).

Additionally, industry (i.e., point source and nonpoint source pollution), mining influences, and land-use changes (i.e., increase siltation from deforestation) are perceived to have had deleterious effects on this system, similar to that of other large rivers (Ward and Stanford 
1995a; Ward and Stanford 1995b; Allan 2004). As early as 1933 Addair (1944) reported negative fish faunal responses to source pollutants into Kanawha River tributaries, such as direct chemical pollution from the dumping of tannery chemicals into Knapp Creek or discharge from a pulp mill into the Cherry River turning it into a white foam for a distance of eight miles. Addair (1944) also commented on excessive sand deposition in Gauley River, which he attributed to past logging practices. He stated that the water spilling over Kanawha Falls was coffee colored from chemical pollution (Addair 1944). During his collection period, the major industries at this time in the main Kanawha River (i.e., below Kanawha Falls) were chemical factories and coal mining, both of which caused a marked decrease in populations of benthic fishes (e.g., catfish and suckers) (Addair 1944).

Because this system had been severely impacted by humans it has been somewhat overlooked by modern ecologists, mirroring large rivers elsewhere (Hocutt et al., 1986; Thorp et al., 2006). This led researchers to conclude that large rivers are experiencing declines of their aquatic fauna (Thorp 1992; Thorp et al. 2006; Freedman et al. 2013). This is reflective of aquatic systems elsewhere in North America that have experienced similar environmental impacts causing extinction and extirpation rates well above that of historic background levels, and rival or exceed all other continents worldwide (Sparks et al., 1990; Burkhead 2012).

Water quality has substantially improved from its severely degraded state prior to the air and water laws of the 1970s (e.g., Clean Air Act 1970 and the Clean Water Act 1977) (Messinger 1997). Fish population assessments indicate these improvements have been particularly beneficial to fishes in wadeable streams and small rivers, where collecting techniques for such habitats are more efficient (Thorp et al. 2006). These evaluations suggest certain species have significantly rebounded in many watersheds, while other species, 
particularly habitat specialists, have not. Studies on large rivers have also been positive, especially relative to the larger fauna and their associated pelagic species; however, accurate assessments of the associated benthic fish fauna have been severely lacking until recently (Everett et al. 2004; Stewart et al. 2005; Herzog et al. 2005; Hamel et al. 2009; Herzog et al. 2009; Koryak et al. 2009; Neebling and Quist 2010; Neebling and Quist. 2011; Parks 2013; Love et al. 2016).

\section{Kanawha River: Native Ichthyofauna}

The lower Kanawha River drainage is known to be the most diverse in West Virginia, with up to 107 species reported as native below Kanawha Falls (Goldsborough and Clark 1908; Addair 1944; Cincotta et al. 1986; Hocutt et al. 1986; Stauffer et al. 1995; pers. comm. D. Cincotta). Several of the fishes in this system are of conservation concern and listed as Species of Greatest Conservation Need (SGCN) pursuant to the State Wildlife Action Plan (SWAP), West Virginia Division of Natural Resources (WVDNR 2015). Twenty-four of these SGCNs are benthic species that could potentially be distributed in the Kanawha River proper. The WVDNR has recognized a data deficiency for these species (Table 1). Much of the data deficiency of this system is due to the nonwadeable nature river and the associated biases associated with the gear types that have been used to historically sample the Kanawha River proper. 


\section{Kanawha River: Historical Sampling}

During 1818, Constantine Samuel Rafinesque first sampled the Ohio River and its tributaries introducing the fishes of this region to the sciences of natural history and ichthyology (Rafinesque 1820). Goldsborough and Clark (1908) made the first attempt to summarize the fishes of West Virginia and added to the work of Rafinesque. John Addair (1944) later assessed the distribution of the ichthyofauna in the entire West Virginia portion of the Kanawha River from surveys conducted primarily in the 1930s. Additional efforts to sample and document fishes in this river system occurred over the next 50 years, which culminated in the 1995 edition of “The Fishes of West Virginia" (Jenkins et al. 1972; Hocutt et al. 1979; Stauffer et al. 1982, Cincotta et al. 1986; Stauffer et al. 1995).

Early studies of this system were conducted primarily with seines and various other nets as they were the typical gear for collecting fishes in those times (Rafinesque 1820; Goldsborough and Clark 1908; Addair 1944; pers. comm D. Cincotta). In later studies of water quality, game fish population, and fish community assessments were conducted via boat-mounted electrofishers, backpack electrofishing, parallel wire units, tote barges, seines, minnow traps, light boxes, gill nets, bongo nets, and rotenone (lock chambers) (Cincotta et al., 1986; Hocutt et al. 1986; Odom et al. 1992; Stauffer et al. 1995; Burns 2007; Niles and Hartman 2009). Most of these gear types are biased toward the collection of larger and/or pelagic species, while performing poorly in the collection of small-bodied benthic fishes in deep environments typical of large rivers (Neebling and Quist 2011; Smith et al. 2016). To date, no documented investigations have been conducted in the navigable Kanawha River via targeted benthic sampling such as benthic otter trawling. 


\section{Lotic Benthic Trawling}

The Kanawha River is not the only large river with a data deficiency of benthic fishes owing to gear biases of conventional fish collection techniques (i.e., electrofishing, gill nets, fyke nets, and seines). Gear biases have led researchers to devise new methods to overcome gear limitations for benthic fishes. By modifying and downsizing marine shrimping trawls, biologists have been able to sample small benthic fishes from lotic environments while also allowing sampling to take place from small vessels (i.e., Jon boats). Examples include the Missouri, MiniMissouri, and the Gerken Siamese Trawls used to sample the Mississippi River and its tributaries (Herzog et al. 2005 and Herzog et al. 2009). Gear types that are now produced and made widely available by Innovative Net Systems.

The adaptation and modifications of benthic otter trawls for the sampling of lotic freshwater environments have resulted in the detection and rediscovery of many benthic fishes previously thought to have been extirpated from a portion of their respective ranges. For example, Western Sand Darters (Ammocrypta clara) were detected in the East Fork Black River, MO, Mississippi River, MS, and by in the Cedar River of the upper Mississippi River system in Iowa (Neebling and Quist 2008 and Herzog et al. 2009); Crystal Darters (Crystallaria asprella) in the Black River, MO, and AR (Herzog et al. 2009); Sturgeon Chubs (Macrhybopsis gelida) and Sicklefin Chubs (M. meeki) in the Yellowstone and Missouri rivers (Everett at al. 2004). Herzog et al. (2009) documented Sicklefin Chubs in the Platte River in 2000 despite eight years (i.e., since 1992) of previous sampling efforts in this river system. Species detections such as these and knowledge gaps associated with benthic-trawled fishes have invigorated the reevaluation of West Virginia's nonwadeable rivers. It was anticipated that the implementation of benthic otter trawling would elucidate understandings of the distributions and habitat use of West 
Virginia's large river benthic fishes. Further, these data are expected to inform management actions pertinent to the conservation of the SGCNs within the Kanawha River proper (WVDNR 2015).

\section{Thesis Objectives}

This thesis responds to the conservation and management needs relevant to SGCNs in the navigable Kanawha River. My research objectives were to 1) update the distribution of the benthic fishes within the navigable Kanawha River, and 2) describe habitat use of these fishes in the Kanawha River. 


\section{Literature Cited}

Addair, J. 1944. The fishes of the Kanawha River system in West Virginia and some factors which influence their distribution. Ph.D. Dissertation. Ohio State University.

Allan, J. D. 2004. Landscapes and riverscapes: the influence of land use on stream ecosystems. Annual Review of Ecology, Evolution, and Systematics 35:257-284.

Argent, D.G., and W.G. Kimmel. 2010. Influence of navigational lock and dam structures on adjacent fish communities in a major river system. River Research and Applications 27:1325-1333.

Argent, D.G., and W.G. Kimmel. 2014. Patterns of ichthyofaunal distribution and connectivity in navigable and free-flowing reaches of a major river system: The Allegheny River in Pennsylvania. River Research and Applications 30:631-638.

Bjorgo, K. A. 2006. Distributional ecology of Kanawha River fish. Doctoral Dissertation. West Virginia University, Morgantown, West Virginia.

Burns, A. D. 2007. Comparison of two electrofishing gears (backpack and parallel wires) and abundance of fishes of the upper Greenbrier River drainage. Master's Thesis. West Virginia University, Morgantown, West Virginia.

Burkhead, N. M. 2012. Extinction rates in North American freshwater fishes, 1900-2010. BioScience 62:798-808.

Everett S. W., Scarnecchia D. 1., and L.F. Ryckman. 2004. Distribution and habitat use of sturgeon chubs (Macrhybopsis gelida) and Sicklefin Chubs (M. meeki) in the Missouri and Yellowstone Rivers, North Dakota. Hydrobiologia 527:183-193.

Freedman, A. J., R. F. Carline, and J. R. Stauffer. 2013. Gravel dredging alters diversity and structure of riverine fish assemblages. Freshwater Biology 58:261-274.

Goldsborough, E. L., and H. W. Clark. 1908. Fishes of West Virginia. Bulletin U.S. Bureau of Fisheries, 27:29-39.

Hamel, M. J., Steffensen K. D., Horner P. T., and S. M. Stukel. 2009. A comparison of fish catch rate with two different benthic trawls in the Missouri River. Journal of Freshwater Ecology 24:625-634.

Hansen, M. C. 1987. The Teays River. Ohio Division of Geological Survey, Ohio Geology Summer: pages 1-6, Ohio.

Kanawha River Basin Coordinating Committee. 1971. Kanawha River Comprehensive Basin Study. Vol. IV. Appendix G. Water Supply and Water Quality Requirements. Department of the Army, Huntington District, Corps of Engineers, West Virginia. 
Herzog, D. P., Barko, V. A. Scheibe, J. S., Hrabik R. A., and D. E. Ostendorf. 2005. Efficacy of a benthic trawl for sampling small-bodied fishes in large river systems. North American Journal of Fisheries Management 25:594-603.

Herzog, D. P., Ostendorf, D. E., Hrabik, R. A., and V. A. Barko. 2009. The Mini-Missouri Trawl: a useful methodology for sampling small-bodied fishes in small and large river systems. Journal of Freshwater Ecology 24:103-108.

Hocutt, C. H., Jenkins, R. E., and J. R. Stauffer JR. 1986. The Zoogeography of North American Freshwater Fishes. Hoboken, New Jersey.

Honick, A. S., Zimmerman, B. J., Stauffer Jr, J. R., Argent, D. G., and B. A. Porter. 2017. Expanded distributions of three Etheostoma darters (subgenus Nothonotus) within the upper Ohio River watershed. Northeastern Naturalist 24:209-234.

Jenkins, R. E., Lachner, E. A., and F. J. Schwartz. 1972. Fishes of the central Appalachians drainage: Their distribution and dispersal, pp 43 - 117. In the Distributional History of the Biota of the Southern Appalachians. Part III: The Vertebrates. P. C. Holt (ed.) Virginia Polytechnical Institute State University, Resource Division Monograph 4, Blacksburg, VA.

Koryak, M., Bonislawsky, P. S., Locy, D. D., and B. A. Porter. 2009. Typical channel-fish assemblage of the recovering lower Allegheny River navigation system, Pennsylvania, USA. Journal of Freshwater Ecology 24:509-517.

Love, S. A., Phelps, Q. E., Tripp, S. J., and D. P. Herzog. 2016. The importance of shallow-low velocity habitats to juvenile fish in the middle Mississippi River. River Research Applications. River Research Applications 33:1-7.

Messenger, T. 1997. Water-quality assessment of the Kanawha-New River basin, West Virginia, and North Carolina - Review of water-quality literature through 1996. USGS WaterResource Investigations Report 97-4075:1-30.

Neebling, T. E. and M. C. Quist. 2008. Observations of the distribution and status of Western Sand Darter, Spotted Gar, and Skipjack Herring in Iowa Rivers. Journal of Iowa Academy of Sciences 115:24-27.

Neebling, T. E. and M. C. Quist. 2010. Relationships between fish assemblages and habitat characteristics in Iowa's non-wadeable rivers. Fisheries Management and Ecology 17: 316-385.

Neebling, T. E. and M. C. Quist. 2011. Comparison of boat electrofishing, trawling, and seining for sampling fish assemblages in Iowa's nonwadeable rivers. North American Journal of Fisheries Management 31:390-402. 
Nielsen, L. A., R. J. Sheehan, and D. J. Orth. 1986. Impacts of navigation on riverine fish production in the United States. Polskie Archiwum Hydrobiologii 33:277-294.

Niles, J. M., and K. J. Hartman. 2009. Larval fish use of dike structures on a navigable river, North American Journal of Fisheries Management 24:1035-1045.

Odom, M. C., D. J. Orth, and L. A. Nielsen. 1992. Investigation of barge-associated mortality of larval fishes in the Kanawha River. Virginia Journal of Science 43:41-46.

Parks, T. P. 2013. Fish assemblages in Iowa's nonwadeable rivers: historic changes in assemblage structure and relationships with natural and anthropogenic environmental characteristics. M.S. Thesis. Iowa State University, Ames, Iowa.

Ray, L. L. 1974. Geomorphology and Quaternary geology of the glaciated Ohio River ValleyA reconnaissance study. U.S. Geological Survey Professional Paper 826:1-77.

Rafinesque. C. S. 1820. Ichthyologia Ohioensis and Natural History of the Fishes Inhabiting the River Ohio and its Tributary streams. W.G. Hunt. Lexington, Kentucky.

Smith, C. D., M. C. Quist, and R. S. Hardy. 2016. Fish assemblage structure and habitat associations in a large western river system. River Research and Applications 32:622638.

Sparks, R. E., Bayley, P. B., Kohler, S. L. and L. L. Osborne. 1990. Disturbance and recovery of large floodplain rivers. Environmental Management 14:699-709.

Stauffer, J. R., Jr., Burr, B. M., Hocutt, C. H., and R. E. Jenkins. 1982. Checklist of the fishes of the central and northern Appalachian Mountains. Proceedings Biological Society Washington 95:27-47.

Stauffer, J. R., J. M. Boltz, and L. R. White. 1995. The Fishes of West Virginia. The Proceedings of the Academy of Natural Sciences of Philadelphia. Philadelphia, Pennsylvania.

Stauffer, J. R., Criswell, R. W., and D. P. Fischer. 2016. The Fishes of Pennsylvania. Cichlid Press, El Paso, TX.

Stewart, J. G., Barko, V. A. Herzog, D. P., Henry, D. B., Ridings, J. W., Kelly, A. F., and J. E. Wallace. 2005. New records of the crystal darter (Crystallaria asprella) in the middle Mississippi River. American Midland Naturalist. 154:471-473.

Thorp, J. H. 1992. Linkage between islands and benthos in the Ohio River, with implications for riverine management. Canadian Journal of Fisheries and Aquatic Sciences. 49:18731882. 
Thorp, J. H., Thoms, M. C., and M. D. Delong. 2006. The riverine ecosystem synthesis: biocomplexity in river networks across space and time. River Research Applications 22: $123-147$.

Tight, W. G. 1903. Drainage modifications in southeastern Ohio and adjacent parts of West Virginia and Kentucky. U.S. Geology Survey Professional Paper 13:1-111.

USACE (U.S. Army Corps of Engineers). 1986. Kanawha river basin water quality modeling. Special projects report 86-5-AD-A203686, Huntington, West Virginia.

Ward, J. V., and J. A. Stanford. 1995a. The serial discontinuity concept: extending the model to floodplain rivers. Regulated Rivers Research and Management. 10:159-168.

Ward, J. V., and J. A. Stanford. 1995b. Ecological connectivity in alluvial river ecosystems and its disruption by flow regulation. Regulated Rivers Research and Management. 11:105119.

WVDNR. 2015. State wildlife action plan. West Virginia Division of Natural Resources.

Charleston, West Virginia. 


\section{TABLES}

Table 2: List of benthic SGCN fishes potentially distributed in the Kanawha River proper.

\begin{tabular}{clll}
\hline Count & Family & Scientific Name & Common Name \\
\hline 1 & Petromyzontidae & Ichthyomyzon bdellium & Ohio Lamprey \\
2 & Petromyzontidae & Ichthyomyzon unicuspis & Silver Lamprey \\
3 & Catostomidae & Carpiodes carpio & River Carpsucker \\
4 & Catostomidae & Carpiodes velifer & Highfin Carpsucker \\
5 & Catostomidae & Moxostoma carinatum & River Redhorse \\
6 & Cyprinidae & Erimystax dissimilis & Streamline Chub \\
7 & Cyprinidae & Erimystax - punctatus & Gravel Chub \\
8 & Cyprinidae & Macrhybopsis hyostoma & Shoal Chub \\
9 & Cyprinidae & Macrhybopsis storeriana & Silver Chub \\
10 & Cyprinidae & Notropis blennius & River Shiner \\
11 & Cyprinidae & Notropis buchanani & Ghost Shiner \\
12 & Cyprinidae & Pimephales vigilax & Bullhead Minnow \\
13 & Ictaluridae & Noturus eleutherus & Mountain Madtom \\
14 & Ictaluridae & Noturus stigmosus & Northern Madtom \\
15 & Percidae & Ammocrypta clara & Western Sand Darter \\
16 & Percidae & Ammocrypta pellucida & Eastern Sand Darter \\
17 & Percidae & Crystallaria cincotta & Diamond Darter \\
18 & Percidae & Etheostoma tippecanoe & Tippecanoe Darter \\
19 & Percidae & Percina copelandi & Channel Darter \\
20 & Percidae & Percina evides & Gilt Darter \\
21 & Percidae & Percina macrocephala & Longhead Darter \\
22 & Percidae & Percina phoxocephala & Slenderhead Darter \\
23 & Percidae & Percina sciera & Dusky Darter \\
24 & Percidae & Percina shumardi & River Darter \\
\hline & & &
\end{tabular}




\section{Chapter 2: Distribution and habitat use of benthic fishes in the Kanawha River, West Virginia}

Introduction

Many of North America's large rivers $\left(>6^{\text {th }}\right.$ order) support diverse assemblages of fishes, particularly those of the greater Mississippi River basin (Pflieger 1971; Sparks 1995, Thorp et al. 2006). This fish species diversity has ultimate and proximate explanations and is influenced, in part, by (1) relationships between habitat diversity and species life history and 2) unique zoogeographic patterns that have occurred over geologic time (Hocutt et al. 1986; Junk et al. 1989; Allan and Flecker 1993). In recent years, these large river systems have been subjected to a plethora of perturbations from humans (i.e., flow regime modification, impoundment, channelization, pollution, agriculture, mining, and land-use changes).

Anthropomorphic alterations have affected the functionality of large river systems. Lock and dams, and altered flow regimes have influenced flood pulse dynamics (Junk et al. 1989), limiting floodplain access necessary for many large river fishes to complete life history requirements (Phelps et al. 2010). Pseudo-lentic environments created by lock and dams have often resulted in cosmopolitan assemblages of fishes (Neebling and Quist 2010; Parks 2013). River channelization, including straightening and dredging, has increased both water velocities and habitat homogeneity. Large river systems have experienced a reduction or elimination of unique functional process zones (i.e., unique habitats caused by fluvial geomorphic characteristics producing various forms of velocity refugia and substrate deposition)(Thorp 1992; Thorp et al. 2006; Love et al. 2016). Alterations and losses of large river habitats impact the ability of many fish species to complete their life history requirements, and many large river 
fishes have experienced population extirpations, or in some cases species extinction (Sparks et al. 1990; Burkhead 2012).

The Kanawha River, a $6^{\text {th }}$ order tributary to the Ohio River located in south-central West Virginia, has a history of anthropogenic impacts (i.e., navigation beginning in the late 1800s, increased water levels, channelization, increased removal from its floodplain, changes in the natural flow regime, land use changes, urbanization, and manipulation of its natural flow regimes). Because of anthropogenic impacts, the mainstem Kanawha River has been somewhat overlooked and undersampled by modern ecologists and ichthyologists (Hocutt et al. 1986; Thorp et al. 2006). In the 1960s the Kanawha River was known as one of the most polluted rivers in North America from industrial and mining influences (i.e., point source and nonpoint source pollution) (Messinger 1997). As a consequence of habitat alteration and pollution, the aquatic fauna of the Kanawha River mainstem has experienced declines (Hocutt et al. 1986, Neilsen et al. 1986; Poff et al. 1997; Bjorgo 2006).

Water quality of many river systems has substantially improved from its severely degraded state prior to the air and water laws of the 1970s (e.g., Clean Air Act 1970 and the Clean Water Act 1977) (Messinger 1997). Fish population assessments indicate improvements have been particularly beneficial to fishes in wadeable tributaries of large rivers, where collecting techniques are relatively efficient (Thorp et al. 2006). Evaluations suggest that populations of certain species have rebounded in many watersheds, while those of other species, particularly habitat specialists, have not. Studies on larger rivers, such as the Kanawha River, have also supported population recoveries, especially relative to pelagic species or those with larger body sizes. However, assessments of the benthic fish fauna of many large river mainstems have been severely lacking, owing in part to biases associated with standard fish collection gear. 
Recently, within the last 25 years, benthic sampling methods, particularly those using bottom trawls, have been effective in assessing benthic faunas of large rivers (Everett et al. 2004; Stewart et al. 2005; Herzog 2005; Herzog 2009; Neebling and Quist 2010; Neebling and Quist 2011; Parks 2013). Bottom trawls, however, have not been used to assess populations of benthic fishes of the Kanawha River mainstem in West Virginia. Thus, our research objectives were to (1) assess the distributions of benthic fishes of the Kanawha River mainstem by using benthic otter trawling, and (2) examine relationships between species occurrence and benthic habitat. Many benthic fishes of large rivers represent species of conservation concern, thus results of this study will inform management decisions relative to the navigable Kanawha River.

\section{Methods:}

\section{Study Area}

The Kanawha River is formed by the confluence of the New and Gauley Rivers just above Kanawha Falls near Glen Ferris, WV in Fayette County. The Kanawha River intersects four counties (Fayette, Kanawha, Putnam, and Mason) as it flows north-west before its confluence with the Ohio River in Point Pleasant, WV. The Kanawha River has four pools (each named by the dam that maintains each respective pool stage); Robert C. Byrd, Winfield, Marmet, and London (Table 1, Figure 1). Each pool is maintained at a minimum depth of $2.74 \mathrm{~m}(9 \mathrm{ft})$. Tributaries of the Kanawha River include Pocatalico, Coal, and Elk rivers, as well as many smaller creeks, such as Ninemile, Tenmile, Hurricane, and Buffalo creeks. Kanawha River was chosen as a study area due to its high fish diversity (107 native species recorded for the drainage), historical records of the species of interest, and lack of benthic specific sampling being completed in this system (Goldsborough and Clark 1908; Raney 1938; Addair 1944; 
Hocutt et al. 1986; Stauffer et. al. 1995;D. Cincotta, West Virginia Division of Natural Resources, personal communication).

\section{Gear}

Benthic trawling was conducted between 12 September and 4 October 2017 and between 29 May and 4 October 2018 with a 2.4-meter (8') wide Gerken Siamese trawl (this gear is nearly identical in construction to the Missouri-Mini trawl (MMT) used extensively in the Missouri and Mississippi Rivers (Herzog et al. 2005; Stewart et al. 2005; Herzog et al. 2009). More recently the MMT has been used in the Ohio, Allegheny, and Monongahela Rivers (Herzog et al. 2009; Koryak et al. 2009; Argent and Kimmel 2010; Argent and Kimmel 2014; Hintz et al. 2015; Smith et al. 2016; Honick et al. 2017). The MMT has two complete bags; a bag with larger mesh inside of a bag with smaller mesh. The GST has a single bag of small mesh $\left(3.2 \mathrm{~mm}\right.$ or $1 / 8^{\prime}$ mesh size) with a larger mesh separation device sewn into the small mesh cod-end, providing the same

function as the larger mesh inner bag of the MMT. Differences in fish capture efficiency between the two gears are negligible (G. Faulkner, Innovative Net Systems, personal communication). Benthic otter trawling has shown to be very effective for the sampling of benthic fishes within medium to large river systems and will provide an appropriate means to capture these small bodied, benthic fishes.

The Gerken Siamese trawl is known as a sling-shot balloon trawl because of its general slingshot shape and the use of floats to open the mouth vertically like a balloon. Two otter doors are used to pull the net to the bottom with the bolch line attached to the footrope or the trawl. This weighted bolch line promotes contact with the bottom but precludes gouging the substrate. Two floats are used on the head rope to open the trawl mouth vertically. In addition to adding 
weight, the otter doors also open the trawl horizontally thus replacing the need for heavy beams to spread the net as used in beam trawls.

Perhaps the most ecologically friendly feature of this gear is the dual cod end. This component uses two distinct sizes of nested netting material, the first being larger mesh (referred to as a separation device) and the second being smaller mesh. This design allows for the safe passage of small individuals (i.e., small fish, snails, and mussels) to the second cod end where they remain excluded and safe from the crushing effect caused by large objects (i.e., rocks, large fish, tires, etc.) that may be picked up in the trawl. The size class of the catch, bycatch, and debris that is allowed passage into the second cod end is dictated by the mesh size of the separation device, we used an $18 \mathrm{~mm}$ square mesh, ultra-high-density polyethylene separation device. This dimension allows for objects of up to $18 \mathrm{~mm}$ (median axis) to pass through the net when not stretched and up to $30 \mathrm{~mm}$ (median axis) when the net is stretched. Using this size mesh in the separation device allows for the separation of small $(\leq 30 \mathrm{~mm})$ mussels, crayfish, snails, and fish. It is imperative to use a trawl with similar separation devices in the Kanawha or waters of West Virginia that contain known or potential distributions of endangered mussels to limit "take" of juvenile mussels by being crushed inside the cod-end of the trawl, pursuant to USFWS section 7 compliance protocols.

Trawl specifications for this study include two $61 \mathrm{~m}(200$ ') tow ropes, two 12 " x 24 " $\mathrm{x}$ 3/4" otter doors weighing $6.5 \mathrm{~kg}$ (14.25 lbs.) each and a Gerken Siamese Trawl (Inn. Net Systems), consisting of $3.2 \mathrm{~mm}$ (1/8”) polyester mesh size with an $18 \mathrm{~mm}$ (13/16”) square mesh separation device. Trawl body dimensions were $2.4 \mathrm{~m}$ wide by $4.3 \mathrm{~m}$ deep (head rope to cod end) with a single $2.4 \mathrm{~m}$ length of bolch line (1/4" link chain) attached to the foot rope. The trawl was fished from the bow of an 18-foot aluminum jon boat with a 75hp outboard engine with a three 
blade $13.5 " * 15$ propeller in a downstream zig-zag fashion per (Herzog 2009; Herzog 2005). Hauls were fished for target distance of 25 meters with $18.28 \mathrm{~m}\left(60^{\prime}\right)$ tow ropes in water depths $\leq 3 \mathrm{~m}\left(10^{\prime}\right), 30.48 \mathrm{~m}\left(100^{\prime}\right)$ ropes for depths $\geq 6 \mathrm{~m}\left(19.7^{\prime}\right)$, and $60.96 \mathrm{~m}\left(200^{\prime}\right)$ ropes for water $>$ 6 meters in depth; providing a 7:1 drop ratio preventing net lift and improper fishing (Honick et al. 2017). Haul length, speed, and location were monitored by GPS. Trawling speed was maintained at a speed slightly faster than the surface velocity but did not to exceed $4 \mathrm{~km}$ per hour (Herzog 2009). Trawling speeds more than $4 \mathrm{~km} / \mathrm{h}(2.5 \mathrm{mi} / \mathrm{h})$ result in a decrease in catch efficiency due to a net positive pressure inside of the net, which can cause small fishes to be pushed out of and away from the mouth of the net, via a pressure wave in the water just in front of the mouth of the trawl for this net configuration (e.g., mesh size) (pers. comm. G. Faulkner).

Benthic trawling was conducted at the nine study locales (Table 1), and five hauls of the benthic trawl were conducted at each of nine habitat types; main channel (MC), main channel border (MCB), island main channel border (IMCB), island head (IH), island toe (IT), island side channel border (ISCB), side channel (SC), side channel border (SCB), and tributary (TRIB) (Table 2; Figure 2). The nine study locales were located from approximately 14 river kilometer (rkm) above the mouth of the Kanawha River (i.e., 0 being the confluence with the Ohio River) to approximately $5 \mathrm{rkm}$ below the head of the navigation channel. A total of four islands were sampled; Blaine Island, Scotts Island, Watsons Island, and Wheeler Island. An island located just downstream of Kanawha Falls was excluded from the study because high densities of endangered freshwater mussels precluded sampling via benthic trawl. Additionally, tributary mouths were sampled at Pocatalico, Coal, and Elk rivers, and at Tenmile, Buffalo, and Hurricane creeks. Study locales are the approximate center point of the sampling area (i.e., hauls conducted above and below each of the nine locales within the navigable Kanawha River). 


\section{Environmental Variables}

A total of 16 environmental covariates were collected within each sample reach (e.g., trawl haul) (Table 3). Water quality parameters were recorded via Yellow Springs Instruments Pro Plus handheld water quality meter at the bottom of the beginning of each haul, parameters included water temperature $\left({ }^{\circ} \mathrm{C}\right), \mathrm{pH}$, conductivity, total dissolved solids, and dissolved oxygen (\% and $\mathrm{mg} / \mathrm{l}$ ) (Table 3). Water velocity was recorded approximately $120 \mathrm{~mm}$ (4.7") above the bottom with an electromagnetic water velocity meter (OTT MF pro; suspended from the bow of an anchored boat). Water depth was recorded via sonar log from a Lowrance Gen 3 total scan. The average water depth for each sample was later extracted from each log via the program Reefmaster®. Additional measurements included distance to the nearest bank, distance to mouth, distance to the nearest upstream dam, and distance to the nearest downstream dam. Dominant and codominant substrate classes were classified via visual estimation from six $228.6 \mathrm{~mm} \mathrm{x}$ $228.6 \mathrm{~mm}$ (9"x 9") Ponar ${ }^{\circledR}$ grab samples throughout the reach of each trawl sample. Substrate samples were classified based on a modified Wentworth Scale (Wentworth 1922), size classes consisting of silt/clay ( $\leq 0.06 \mathrm{~mm}$ ), Sand (>0.06 to $2 \mathrm{~mm}$ ), gravel (fine) (>2 $\mathrm{mm}$ to $16 \mathrm{~mm}$ ), gravel (coarse) (> $16 \mathrm{~mm}$ to $64 \mathrm{~mm}$ ), cobble/boulder (> $64 \mathrm{~mm}$ to $4096 \mathrm{~mm}$ ), bedrock (> 4096) and coarse organic substrate (particle size: $1 \mathrm{~mm}$ to $20 \mathrm{~mm}$ ) (Table 4) (Everett et al. 2004). In addition to taking grab samples, substrate was classified with a sounding weight at the beginning and end of each haul, which assured proper grading of substrates that exceeded jaw dimensions of the Ponar ${ }^{\circledR}$ apparatus.

\section{Fish data}

Fishes captured from each haul were euthanized by MS222 (e.g., Tricaine Methanesulfonate) and then preserved in a $10 \%$ solution of formalin and cataloged as an 
independent sample. Retained specimens were identified to species level if their condition and size allowed using regional fish keys (Trautman 1981; Etnier and Starnes 1993; Jenkins 1994; Stauffer et al. 1995; Pfliger 1997; Page and Burr 2011; Stauffer et al. 2016) and verified by regional experts. Species were enumerated, and size was measured as standard and total lengths; large fishes were identified, weighed, measured, cataloged (i.e., photo voucher), and released. Catch per unit effort (CPUE) was recorded based on trawl time (i.e., measured from time tow lines become taut and the net is retrieved) as well as linear distance sampled (distance between when net begins fishing (e.g., ropes taut and when reverse load is ceased and retrieval begins) (Herzog et al. 2005; Love et al. 2016)

\section{Statistical Methods}

We used canonical correspondence analysis (CCA) to explore possible associations between benthic fishes and habitat parameters. Fish assemblage structure and their respective relationships with environmental gradients were described using taxonomic classifications (i.e., species level) (Muller and Pyron 2010; Neebling and Quist 2010; Phelps et al. 2011; Parks 2013). Relative abundances of fishes captured per haul were calculated as catch-per-unit-effort (CPUE). CPUE was calculated for CCA analysis as the number of fish captured by linear distance sampled [i.e., the number of individuals/ trawled distance (m)]. These CPUE data were $\log$ transformed [e.g., $\log (\mathrm{x}+1)$ ] to address assumptions of this model structure (McCune and Grace 2002; Mueller and Pyron 2010; Legendre and Legendre 2012; Parks 2013; Blanchet, Legendre, and Borcard 2018). Species that occurred at less than 10\% of hauls (post removal of hauls resulting in no catch) were removed from the analysis to reduce the effect of rare species (McCune and Grace 2002), resulting in 16 species meeting the criteria for analysis (Table 9). Additionally, sites were also removed from the analysis due to no observations of a single 
species that occurred at a frequency of $\geq 10 \%$ (i.e., $\geq 31$ observations across all hauls). A total of 306 sites (i.e., individual trawl hauls) were included in CCA analysis.

A-priori descriptor variables were used for CCA, consisting of the habitat of each sample (i.e., tributary, island head, island toe, side channel, side channel border, island side channel border, main channel border, and main channel) (Table 2) (Love et al. 2016). Welch post - hoc tests were conducted between different habitat variables to investigate the potential of reducing the total dimensionality (i.e., total number of parameters) by combining habitats to tributary, island tips (head and toe), side channel habitats (i.e., side channel, side channel border, and island side channel border), main channel border habitats (i.e., main channel border and island main channel border), and main channel. Combining these habitats would reduce the total number of qualitative habitat parameters estimated by 4 (e.g., 9 to 5 parameters). Results from Welch tests suggested that significant information could be lost by combining these terms due to significant differences between groups while comparing their respective mean depths and bottom water velocities. Island heads and toes significantly differed in terms of average bottom water velocity [p-value $=0.0018, \alpha=.0027$ (e.g. $\alpha=0.1$ Bonferroni adjusted for 36 comparisons)], Average velocity also differed between main channel border ( $\mathrm{p}$-value $=0.0008, \alpha=.0027$ ) from the island main channel border. Water depth differed between side channel habitat vs island side channel border $(\mathrm{p}$-value $=0.0219)$ and side channel vs side channel border habitats and ( $\mathrm{p}$-value $=0.0137)$. All nine habitat variables were included in CCA model selection procedures to avoid explanatory information loss. Means and standard deviations of depth, bottom water velocity, and other continuous covariates are provided by habitat type in Table 5 .

Substrate data were classified in the field as dominant size classes; silt, sand, gravel fine, gravel coarse, cobble/bolder, bedrock, and coarse organic matter. The data were reclassified for 
analysis, as dominant fine substrate (e.g., silt, sand, and gravel coarse), dominant coarse substrate (gravel coarse and cobble bolder), bedrock, and coarse organic matter. Continuous variables used in this analysis were the distance to mouth [i.e., river kilometer (rkm)], distance to nearest upstream and downstream dams $(\mathrm{km})$, average depth $(\mathrm{m})$, and the distance to the nearest bank (m). An additional binary variable of sample substrate composition consisting of $>10 \%$ sand was included. All pairs of environmental predictor variables (excluding orthogonal categorical variable) were evaluated for strong correlations (i.e., Pearson's $r \geq|0.70|$ ) resulting in 2 of the 26 variables being significantly correlated and included in model selection. Due to the strong correlation $(\mathrm{r}=0.98)$ between total dissolved solids and specific conductance only specific conductance was used in the analysis. The remaining 25 environmental predictors were included in forward model selection procedures.

Model selection procedures were conducted using a forward-selection procedure with Monte Carlo permutation tests (1,000 permutations) to retain environmental explanatory information ( $\mathrm{P} \leq 0.05)$ while simultaneously reducing the amount of overfitting (i.e., parsimony) (ter Braak and Similauer 2002). The resulting final parsimonious model's explanatory variables were assessed in terms of their respective variance inflation factors (VIFs) with the largest VIF value $=11.62)$. Permutation tests were conducted to evaluate the final model [i.e., Ho: that no relationship exists between the response data and the explanatory matrix (e.g., selected model)]. This was achieved by permutating the response data (i.e., a matrix of $\log +1$ transformed observed fish catch per unit effort) at random and comparing the amount of explained variance between observed data and permutated data (i.e., random) via the pseudo-F test statistic [e.g., $F=\frac{S S\left(\frac{\widehat{Y}}{m}\right)}{R S S} /(n-m-1)$. Where $m$ is the number of canonical eigenvalues (i.e., degrees of freedom of the model), SS( $\widehat{Y})$ (explained variation) the sum-of-squares of the table of fitted 
values, and RSS (residual sum of squares) (i.e., total sum-of-squares of Y, SS(Y), minus $\operatorname{SS}(\widehat{Y})$. This principle (i.e., permutational pseudo-F test) was also conducted on the individual CCA axes and the explanatory variables used in the final forward selected model (e.g., terms) to evaluate their significance of explanatory power [i.e., Ho: that either the axis or term explains no more of the variation in the observed response matrix than that of a random (e.g., permuted) dataset] (Blanchet, et al. 2008; Borcard et al. 2018).

Variance partitioning was conducted on the final forward selected model by means of partial CCA (pCCA). The pCCAs elucidated the relative explanatory information contributed by either the predictors of water quality or predictors consistent with physical habitats independently and the amount of information shared between the two sets. The amount of inertia explained relative to the total amount of constrained inertia is referred to as explained variance (\%) (ter Braak and Smilauer 2002). Relative amounts of explained variance (\%) for each suite of environmental characteristics (e.g., water quality predictors and physical habitat variables) were achieved by conditioning (e.g., removing the background variation explained from both explanatory sets) to elucidate the unique explanatory information provided from each set (i.e., pCCA). This can be thought of as removing the center (i.e., overlapped portion) of a Venn diagram where you are left with only the unique unshared portion of information.

Welch tests, paired variable Pearson correlations, CCA model fitting, CCA model selection, permutational pseudo-F tests, and VIF assessments were conducted in the vegan package in program $\mathrm{R}$ and final CCA ordinations (i.e., plot creations) performed using the same fitted final model in the program PC-ORD 7.07 (version 2.5-4) (McCune and Mefford 2018; R Core Development Team 2019). 


\section{Results}

\section{Data Summary}

During this study, a total of 328 hauls were conducted resulting in 318 successful hauls, or a $96.95 \%$ rate of success $( \pm 1.58 \%, \alpha=0.05)$. Successful hauls were defined as trawl hauls pulled for $\geq 20 \mathrm{~m}$ without snagging and resulting in at least one fish captured. These 381 samples collected a total of 49,118 individuals, across 10 families (Table 6). Fifty-three species were collected during this study, 17 of which represented benthic species of greatest conservation need (Table 6).

As expected, depths of the main channel (mean $=6.21, \mathrm{SD}= \pm 1.68)$ exceeded those of all other habitat types. Interestingly, side channel habitats differed less in terms of depth than other habitat types from main channel as considerable overlap exists between them (i.e., side channel mean $=5.00, \mathrm{SD}= \pm 0.98)$. The IH habitats were shallowest $($ mean $=2.58, \mathrm{SD}= \pm 1.70)$. Average bottom water velocity was for $\mathrm{IH}$ habitat (mean $=0.142, \mathrm{SD}= \pm 0.08$ ) was considerably higher from that of IT habitat (mean $=0.060, \mathrm{SD}= \pm 0.03$ ). Bottom water velocities were similar for main channel borders $($ mean $=0.042, S D= \pm 0.03)$ and tributary habitats $($ mean $=0.046, S D$ $= \pm 0.03)$.

Specific conductivities were lowest in SCB habitats (mean $=145, \mathrm{SD}= \pm 10.29)$ and highest around tributary mouths (mean $=319, \mathrm{SD}= \pm 267.09)$. Total dissolved solids followed a similar trend as specific conductivity with the lowest TDS $(\mathrm{mg} / \mathrm{l})$ concentrations at $\mathrm{SCB}(\mathrm{mean}=$ $94, \mathrm{SD}= \pm 6.70)$ and the most concentrated found in tributary habitats (mean $=209, \mathrm{SD}=$ \pm 172.70 ) (Table 5). Temperature $\left(\mathrm{C}^{\circ}\right)$ was the most variable in tributary habitats $($ mean $=24.9$, $\mathrm{SD}= \pm 2.51)($ Table 5) 
Dissolved oxygen $(\mathrm{mg} / \mathrm{l})$ values were similar between habitat types, where standard deviations overlapped considerably among habitat types during the study period (Table 5). Values of $\mathrm{pH}$ also were similar among habitats with 0.36 being largest difference in mean $\mathrm{pH}$ values.

\section{Distribution:}

I documented new distribution records for seven species in the Kanawha River proper [e.g., Western Sand Darter (Ammocrypta clara), Tippecanoe Darter (Etheostoma tippecanoe), Gilt Darter (Percina evides), Longhead Darter (Percina macrocephala), Slenderhead Darter (Percina phoxocephala), River Darter (Percina shumardi), and Blue catfish (Ictalurus furcatus)] (Table 7). All seven species are listed as SGCNs by the West Virginia Division of Natural Resources. This raises the species richness of the Kanawha River proper from 94 to 101 species representing a 7\% increase in species richness.

The Ohio River drainage is the only region where Eastern Sand Darters and Western Sand Darters populations are known to overlap (Cincotta and Welsh 2010), and they are the only two Ammocrypta to exist sympatrically (Near et al. 2000). In West Virginia, the Western Sand Darter (WSD) was discovered in the Elk River in 2006 and confirmed from previously misidentified specimens (museum lots from 1986, 1991, 1995, 2005, and 2006). Though it was previously documented from the lower $36 \mathrm{rkm}$ of the Elk River (representing the only area were WSDs occur in WV), we were able to confirm its presence from within the Kanawha River proper $(\mathrm{n}=16)$. These 16 individuals were distributed throughout three pools [e.g., Robert $\mathrm{C}$. Byrd (RCB), Winfield, and Marmet), consisting of 1 (19 mm TL), 7 (25-52 mm TL), and 8 (24$33 \mathrm{~mm}$ TL) individuals, respectively. The collection of these individuals supports a wider geographic distribution of WSD in WV. These new records expand the previously known 
distribution within the state by a total of $80 \mathrm{rkm}$ in the Kanawha River (i.e., $27 \mathrm{rkm}$ below and 53 rkm above the Elk River mouth) with 1 individual collected below the Winfield dam and 8 individuals above the Marmet Lock and Dam.

The Tippecanoe Darter is currently under a species status assessment review by the US Fish and Wildlife Service (USFWS) for potential listing pursuant to the Endangered Species Act (USFWS 2018). During our efforts we collected 21 individuals throughout all four pools of the Kanawha River (e.g., RCB, Winfield, Marmet, and London) represented by 5 (22-32mm TL), 4 (19-27mm TL), 7 (20-28mm TL), and 5 (17-24mm TL) individuals respectively. These individuals represent a downstream distribution extension into the navigable Kanawha River; prior to my collections it was previously known from the Elk, Ohio, and Little Kanawha river drainages in WV (WVDNR unpublished data; Honick et al. 2017). The population of Tippecanoe Darters in the Kanawha River may provide genetic connectivity between populations in the Elk and Ohio rivers.

New downstream distribution records were also documented for the Gilt and the Longhead darters. The Gilt Darter $(\mathrm{n}=2)$ was recorded less than 3rkm below the Winfield Dam (i.e., RCB pool) at the Hurricane - Buffalo Creek locale (i.e., rkm 27 - 30). The previously documented distribution of this species in West Virginia included only the Ohio, Big Sandy, and the Elk rivers (Stauffer 1995; Zimmerman and Rice ). We also documented the Longhead Darter in the Kanawha River proper, collecting seven specimens from the Winfield pool (Rkm $54-58)$. One individual (55mm TL) was collected from a tributary sample (Elk River) and 6 individuals $(21-24 \mathrm{~mm}$ TL) were collected from the side channel and toe of Blaine Island. We also documented the Longhead Darter in the Kanawha River proper, collecting seven specimens from the Winfield Pool (rkms 54-58). One individual (55 mm TL) collected from a tributary sample 
(Elk River) and 6 individuals (21-24 mm TL) taken from the side channel and toe of Blaine Island. Collections of Gilt and Longhead darters represent the first documentation from the main channel Kanawha River.

Slenderhead Darters $(\mathrm{n}=15)$ were collected from four pools $(\mathrm{RCB}$, Winfield, Marmet, and London) with observed abundances of $1,1,12$, and 1 respectively. These individuals represent the first observations for the Kanawha River proper. Interestingly, this species is often one of the more common darters collected in other studies of large rivers (Herzog et al. 2005; Herzog et al. 2009; Rice and Zimmerman 2019). The previously-known range of this species in West Virginia was from the main channel and certain backwaters of the Ohio River and the lower reaches of the Little Kanawha and Middle Island Creek (Stauffer et al.,1995; Rice and Zimmerman, 2019; WVDNR, unpublished data).

Our detections of the River Darter represent a new distributional record for the Kanawha River proper as well as the drainage. We collected a total of seven specimens in the Robert C. Byrd $[\mathrm{n}=4(40-62 \mathrm{~mm}$ TL)$]$ and Winfield $[\mathrm{n}=3(67-85 \mathrm{~mm}$ TL)$)$ pools. This new information extends the current range of this species in West Virginia from the Little Kanawha and Ohio Rivers into the Kanawha River (Rice and Zimmerman 2019; WVDNR unpublished data). These specimens of the River Darter were collected between the rkms 9-11 and 28-30 in the RCB pool and between rkms $53-59$ in the Winfield pool.

Lastly, we found evidence of natural reproduction of the Blue Catfish (Ictalurus furcatus), a species that is reported to be native to the Ohio River and expected to be present in the lower Kanawha. Though stocked by WVDNR no evidence of an established population (i.e., natural reproduction) has been found from the drainage to date (Stauffer et al. 1995; pers. comm. D. Cincotta). These specimens represent the first collections of naturally occurring Blue Catfish 
from the drainage and likely resultant from the recently (within the last 15 years) stocked adults in the Ohio River in all its respective pools, including the Robert C. Byrd (i.e., the lowest pool in the Kanawha River). We collected 17 specimens (44-64 mm TL) and 15 specimens (37-91 mm TL) from the Robert C. Byrd (7-10 rkm) and Winfield (37-46 rkm) pools respectively. This is the first evidence of Blue Catfish reproduction in West Virginia after this species was considered as extirpated from its waters.

Forty-six other species were collected during this study, 13 of which have SGCN rank; Ohio Lamprey (Ichthyomyzon bdellium), Streamline Chub (Erimystax dissimilis), Shoal Chub (Macrhybopsis hyostoma), Silver Chub (Macrhybopsis storeriana), Ghost Shiner (Notropis buchanani), Bullhead Minnow (Pimephales vigilax), River Carpsucker (Carpiodes carpio), Warmouth (Lepomis gulosus), Orangespotted Sunfish (Lepomis humilis), (Eastern Sand Darter (Ammocrypta pellucida), Channel Darter (Percina copelandi), and the Dusky Darter (Percina sciera). Two of these species (e.g., the Ohio Lamprey and Warmouth) were represented in the collection by single specimens. The Ohio Lamprey was collected from locale number 5 (e.g., Blaine Island) in the Winfield Pool and the Warmouth specimen from the RCB pool between 27 and 28 rkms above the mouth (i.e., locale 2). Additionally, two species with SGCN status are represented by only two individuals (i.e., River Carpsucker and Dusky Darter); the former was collected from two samples in both the RCB pool (locale 1) and the Winfield pool (locale 4), and the latter specimen taken from each of the locale numbers 4 and 6 (i.e., Coal River and Elk River mouths), representing the first collections from the main river (i.e., Kanawha) in the Winfield pool. Prior collections of the Dusky Darter in the mainstem Kanawha River include two sites near Kanawha Falls (WVDNR unpublished data). 
The Silver Chub (Macrhybopsis storeriana), a species with current SGCN status, was previously collected from Kanawha River at its mouth in 1951 and during two lock chamber surveys in the Winfield and Marmet locks in 1981 and 1982, respectively (WVDNR unpublished data). Our specimens $(n=27)$ update the temporal distribution of Silver Chubs within the Kanawha River. The distribution within the river did not change substantially as their presence was only detected in pools with prior occurrence records. Specimens were observed from the RCB pool $[\mathrm{n}=19(27-34 \mathrm{~mm}$ TL)] between rkms 7-10 and 28-30 and in the Winfield pool [n= 8 (40-115 mm TL)] between rkms 38-40, 44-46, and 52-55 (i.e., locales 1,2,3,4, and 5, respectively; Table 1).

The Shoal Chub (Macrhybopsis hyostoma), also with SGCN status, was previously collected from the Kanawha River in lock chamber surveys $(n=20)$ at all four lock and dams (e.g. RCB, Winfield, Marmet, and London) between the years 1978 to 1997 by WVDNR staff. Also, in 1935, Addair (1944) observed them at two locations (i.e., near Marmet Dam and at the mouth of Paint Creek). The state-wide extent of this species includes the Ohio, Elk, Big Sandy, and Guyandotte river drainages. During our sampling, we collected Shoal Chubs from all four pools $[\mathrm{n}=100(13-48 \mathrm{~mm}$ TL) from locales $1,3,4,5,6,7,8$, and 9. We did not observe Shoal chubs at locale 2 (i.e., Buffalo Creek to Hurricane Creek) located 1 - 4 rkms below Winfield lock and dam.

Ghost Shiners are listed as one of West Virginia's SGCN, yet they represented the highest abundance across all species $[\mathrm{n}=24,933(13-51 \mathrm{~mm}$ TL)]. They were previously represented by 13 collections between the years 1935-2000 throughout all 4 pools (i.e., lock chamber surveys at all 4 dams) (Addair 1944; Stauffer et al. 1995; WVDNR unpublished data). This species is relatively widespread in many large rivers of West Virginia, and has been 
collected from all major tributaries to the Ohio River. This species was represented by relatively low abundances across all statewide collection records (23,033 individuals) between the years 1931-2016, compared to the 24,933 individuals collected during this study(WVDNR unpublished data). With the use of a benthic trawl, we were able to confirm that this species is abundant in the Kanawha River.

The Bullhead Minnow was the $6^{\text {th }}$ most abundant $(\mathrm{n}=1268)$ species encountered during our trawl efforts. This species was previously collected in the Kanawha River by Addair (1944) $(\mathrm{n}=6)$ during 1935-1936 in the upper three pools (i.e., Winfield, Marmet, and London). Also, this species was collected during a lock chamber survey at London Lock and Dam in 1976 (Stauffer et al. 1995). The specimens from the benthic trawl study fill in spatial gaps of the species distribution within the Kanawha River, providing the first records in the Kanawha River in 42 years. The relatively high abundances of the benthic trawl collections suggest that this species may be more stable and more common than previously thought.

Eastern Sand Darters historically were collected in the Marmet and London pools at four different sites. Three sites were sampled between the years 1931 and 1935 , and a $4^{\text {th }}$ site was collected in 2014 (Addair 1944 and WVDNR unpublished data). During our collections we observed a total of 183 individuals (15-58mm TL) throughout all four pools in the Kanawha River proper, including RCB $(\mathrm{n}=32)$, Winfield $(\mathrm{n}=51)$, Marmet $(\mathrm{n}=46)$, and London $(\mathrm{n}=54)$. Eastern Sand Darters were observed from at least one haul per sampling locale suggesting that the population in the Kanawha River could be more robust than previously thought (Table 1). The benthic trawl results extended the known range of this species within the Kanawha River, and supports the possibility for population connectivity among populations within West Virginia (i.e., Ohio, Elk, Coal, Little Kanawha, Guyandotte, and Big Sandy rivers and Middle Island 
Creek drainages) (Addair 1944; Stauffer et al. 1995; Zimmerman unpublished data; WVDNR unpublished data).

Bluebreast Darters were previously known from two locations in the Kanawha River, one at Kanawha Falls and the second at the first riffle above the navigational channel (WVDNR unpublished data). During our effort, we collected a total of 292 individuals (11-45mm TL), these individuals were taken at locales $1,2,5,6,7,8$, and 9. Though these specimens do not update the temporal distribution substantially (i.e., 4 years, 2014-2018), they do extend the known range of Bluebreast Darters into all four pools of the Kanawha River (e.g., 84 rkm downstream), suggesting the possibility of connectedness to the Ohio River populations (Honick et al. 2017; Rice and Zimmerman 2019).

The Channel Darter was previously known to occur in the Kanawha River in the Winfield, Marmet, and London pools. These individuals were captured from four sites either in or around the London and Marmet lock and dams (i.e., lock chambers and slack waters around dams) and at the mouth of Paint Creek between the years 1935 and 2000. Our efforts update the known distribution temporally by 18 years and extend its known range downstream to locale 1 (Figure 1; Table 1) (e.g., 60 rkm downstream and 7 rkm).

Distribution maps of all species on the SGCN list are provided in Appendix 1 and 2 except for Ohio Lamprey, Warmouth, and River Carpsucker due to a low number of observations (i.e., $\mathrm{n}=1,1$, and 2 respectively). These maps display benthic trawling data and previous data for the Kanawha River proper. Additional species distribution maps of Bigeye Chub (Hybopsis amblops), and Channel Catfish (Ictalurus punctatus) are also provided. Specimens that represented important distributional records are labeled and deposited into the West Virginia 
Wildlife Resources (WVWR) reference collection at the West Virginia Division of Natural Resources Elkins Operations Center located in Elkins, West Virginia.

\section{CCA Results}

Twenty-five environmental predictors were considered during forward selection procedures (Table 8), and 16 variables were retained in the final parsimonious CCA model. The final model used the additive effects of physical habitat predictors; distance to mouth (i.e., rkm), average water depth, average bottom water velocity, distance to nearest upstream dam, distance to nearest downstream dam, dominant fine substrate, and the sampling habitats of main channel, island main channel border, island side channel border, side channel border, side channel, and island head (Table 2). Water quality parameters that were included in the final model consisted of bottom water temperature $\left(\mathrm{C}^{\circ}\right), \mathrm{pH}$, dissolved oxygen $(\mathrm{mg} / \mathrm{l})$, and secchi depth $(\mathrm{cm})$.

Environmental variables included in the final model explained $37.2 \%$ of the total variation in the species dataset $\log (\mathrm{CPUE}+1)$ (i.e., 1.07 of the total inertia of 2.88). The first three axes of the CCA collectively contained $26.89 \%$ of the total explained variation (e.g., constrained inertia) with $15.84 \%, 6.88 \%$, and $4.16 \%$ for axis 1,2 , and 3 , respectively. Axes 1,2 , and 3 consisted of eigenvalues of $0.456,0.198$, and 0.119 , respectively, of the total 1.070 constrained inertia. Permutation tests of the constrained axes 1, 2, and 3 supported statistical significance $($ Pseudo $-\mathrm{F}$ statistics $=73.1,31.8$, and 19.2 for CCA axes 1, 2, and 3 respectively; p-values $=0.0009$ for axes 1,2 , and 3).

Axis one (15.8\% of constrained inertia) was driven primarily (e.g., $\left.\mathrm{r}^{2} \geq 0.2\right)$ by distance to mouth (rkm) and distance to dams both upstream and downstream dams. Secondary explanatory gradients of axis $1\left(\mathrm{r}^{2} \geq 0.05\right)$ consisted of physical habitat variables ISCB, IMCB, 
MC, depth, fine substrates, and water quality parameters of temperature and secchi depth (i.e., turbidity), and bottom water temperature. Axis 2 (6.88\% of constrained inertia) primary being driven by distance to downstream dams and secondarily IMCB, rkm, and $\mathrm{pH}$. Axis 3 (4.16\% of constrained inertia) was most influenced by the average depth and average velocity secondarily it was influenced by habitats IH and SCB, distance to downstream dam, and distance to upstream dam, and $\mathrm{pH}$.

Variance partitioning resulted in predictors associated with physical habitats (i.e., IH, IT, ISCB, MC, average depth, average velocity, dominant fine substrates, distance to upstream and downstream dams, and $\mathrm{rkm}$ ) accounting for $27.86 \%$ of the total variation in the species dataset (i.e., inertia) and $74.93 \%$ of the total constrained variation (i.e., constrained inertia). Factors associated with water quality constrained $5.38 \%$ of the total variation and accounted for $14.47 \%$ of the explained variation. A portion of constrained inertia (10.60\%) could not be exclusively attributed to physical or water quality predictors and therefore was shared between the two sets.

The positions of the species points (i.e., coded by the first two letters of their respective genus and species epithet) (Table 9) in the ordination space represent their relative associations (i.e., relative abundance maxima) with each respective environmental gradient (i.e., linear combinations of explanatory variables)(Figures 3, 4, and 5). Projecting lines from each environmental gradient vector at right angles to a plotted species of interest reveals its relationship with each respective environmental variable (e.g., vectors displayed as red lines with arrows in CCA ordinations)(Figures 3,4, and 5).

The position of Ghost Shiners suggests that this species used deeper environments containing fine substrates with relatively slower bottom water velocities in main channel habitats (Figures 3 and 4). This is in contrast with a closely related species (i.e., volucellus group) the 
Mimic Shiner (Notropis volucellus). The ordination position of Mimic Shiners suggests an association with comparatively shallower areas with increased water velocity. Further, Mimic Shiners were more frequent in less turbid (e.g., deeper secchi depth) habitats that are a greater distance from the mouth than Ghost Shiners (Figures 3 and 5). Channel Shiners (Notropis wickliffi), another volucellus group member, and Mimic Shiners were found in similar environments with the exception that the Mimic Shiner was more closely associated with island habitats, likely due to increased habitat heterogeneity. Channel and Mimic Shiners were the most interspecifically correlated between the three species $(r=0.37)$, Mimic Shiners were least correlated to Ghost Shiners $(r=0.06)$, and Channel and Ghost Shiners were the most intermediately correlated of the three $(r=0.19)$. Channel Shiners were detected from 240 samples (e.g., sites) representing the most ubiquitous species, followed by Ghost Shiners (number of detections $=164$ ); however, Ghost Shiners contributed the largest total relative abundance.

The Easter Sand Darter's position in ordination suggests that it is associated with island habitats especially side channel habitats and areas with slightly faster bottom water velocity (Figure 3).This is likely because island toes provide unique fluvial geomorphic characteristics that allow for the deposition of sand. The distributions of the other three darter species analyzed (i.e., Channel Darters, Bluebreast Darters, and Johnny Darters) also appear to be influenced by island habitats as they appear clustered with Smallmouth Bass, Bigeye Chub, and Bluntnose Minnows.

This study found that Channel Darter's relative abundance maxima existed around side channel habitats, but over coarser substrate with increased flow when compared to Eastern Sand Darters (Figure 3). Sand Darters were positioned slightly to the right of other darter species in 
the ordination, a result owing likely to fine substrates being more strongly positively correlated with axis 1 . Additionally, Sand Darters were associated with dominantly cobble substrate, where sand was present as a subdominant substrate class. Bluebreast Darters were also most relatively abundant in island habitats (i.e., ISCB, SCB, and IMCB) though their relative position to Eastern Sand Darters and Channel Darters indicate they use areas with comparatively increased bottom water velocity. Also, Bluntnose Minnows used similar habitats to that of Channel Darters, as suggested by their proximity in ordination (Figure 3).

Four species that were less associated with island habitats were Bullhead Minnows, Channel Catfish, Freshwater Drum, and Shoal Chubs. Bullhead Minnows most highly correlated with axis $2(r=-0.205)$ and secondary correlated with axis $1(r=0.187)$. This species was influenced primarily by warmer stream temperatures, relative proximity to upstream and downstream dams, and main channel habitats. The ordination location of Channel Catfish and Freshwater Drum suggested that they are more frequently found in deeper main channel habitats over fine substrates. Because these species were most correlated with axis 1 ( $r=0.292$ and 0.289 respectively) these data suggest distance to upstream dams was influential to their distribution as well (i.e., with increasing distance from the outflow of a dam, relative abundances of both species are expected to increase); (Figure 3 and 4). Shoal Chubs were associated with decreased turbidity (i.e., increased secchi depth), and increased velocity over relatively fine substrates (Figures 3 and 4). This species was also associated with island habitats, but was not restricted to island areas. Lastly, Shoal Chub relative abundances were highest in reaches of the river that are farther from the mouth (Figure 4). 


\section{Discussion}

Small benthic trawls have been used successfully to sample small benthic fishes in large rivers, often in areas where these species were previously undocumented or thought to be extirpated (Everett et al. 2004; Herzog et al., 2005; Neebling and Quist 2008; Herzog et al. 2009; Barko et al. 2009; Honick et al. 2017). In our study, benthic trawling resulted in new distribution records for seven species in the Kanawha River mainstem (i.e., Western Sand, Tippecanoe, Gilt Darters, Longhead, Slenderhead, River darters, and Blue Catfish). These seven species were possibly present but not detected during historic sampling, likely owing to gear bias of previously-used sampling techniques. Neebling and Quist (2008) found that as much as $25 \%$ of the ichthyofauna can be overlooked by using just electrofishing and seining alone.

The detections of the Western Sand Darters in the Kanawha River proper indicate that they are more widely distributed than previously thought (i.e., they are not restricted exclusively the lower reaches of the Elk River) (Cincotta and Welsh 2010). Western Sand Darters were collected more infrequently $(n=16)$ than their sister species the Eastern Sand Darter $(n=186)$, however, they were consistently collected sympatrically here with the exception of a single sample (e.g., trawl haul). Because they were primarily collected together it may benefit managers to preserve habitats associated with Eastern Sand Darters at larger spatial scales to foster Western Sand Darters, even though known differences in substrate size preference exist (Thompson et al. 2017).

The Tippecanoe Darter exhibits a disjunct distribution across much of its range (Honick et al. 2017). The WV populations were previously known only from in the Elk River and Little Kanawha River drainages. Our data support the findings of Honick et al. 2017 by suggesting that this species may be repopulating former waters via non-wadeable rivers. Because, we were able 
to elucidate the presence of this species in the Kanawha River proper by implementing targeted benthic sampling (i.e., GST), we cannot be sure that this darter was truly absent or undetected from previous collection techniques and the paucity of sampling. Here it is recommended that future WVDNR large river surveys incorporate trawling along with standard electrofishing and seining procedures to detect Tippecanoe Darters and other benthic species that are expanding their distributions in West Virginia.

Gilt Darters $(n=2)$ were only detected from locale 2 (i.e., Hurricane Creek/Buffalo Creek). These two specimens represent the only Gilt Darters collected in the Kanawha River proper and their presence likely is a result of improvements in water quality. Also, decreased levels of embeddedness likely exist at this locale comparatively to others because these specimens were collected within 3 rkms below Winfield Lock and Dams. Increased flows during high water events likely scour the rocky substrates in the main channel where these specimens reside. Rice and Zimmerman (2019) had similar findings as the majority of Gilt Darter detections were from the Ohio River (76.9\% of all statewide records for Ohio) below lock and dam installations, on gravel bars, and at the heads of islands. These areas likely mimic the conditions of swifter runs and riffles and expose larger substrate that this species is more regularly associated with.

Detections of Longhead Darters in the Kanawha River proper represent the only specimens from the Kanawha River proper though it is known from elsewhere in the drainage. Relatively few individuals $(\mathrm{n}=7$ ) were collected in close proximity (e.g., $0-5$ rkms downstream, locales 5 and 6, Table 1) of the Elk River, which harbors the only viable population in the state (D. Cincotta personal communication). Our data do not reflect the recent range extensions in the Allegheny River system (Herzog et al. 2009, Stauffer et al 2016). This suggests that the 
Kanawha River may not be appropriate habitat for the Longhead Darter or that the species may be limited in its ability to recolonize the Kanawha River proper. If distribution expansion of Longhead Darters is hindered by an unforeseen barrier to recolonization, managers may consider translocation of individuals into suitable WV watersheds to foster the repatriation of this species across its range

Fifteen Slenderhead Darters were collected throughout the four pools in the Kanawha River. This species is represented fairly consistently throughout its range in studies of other large rivers when sampled with benthic trawls, including the Ohio River (Herzog et al. 2009; Rice and Zimmerman 2019). These individuals represent the only Slenderhead Darters to be collected from the Kanawha River drainage likely due to paucity of sampling in the Kanawha River proper and gear bias associated with previously used techniques used. This lack of benthic specific sampling in this nonwadeable system possibly led researchers to conclude its absence from this system (Stauffer et al. 1995).

Detections of River Darters $(n=7)$ from the Kanawha River proper represent a drainage record for this species. Rice and Zimmerman (2019) and Stauffer et al. (2016) suggest this species is recovering and expanding its range due to improvements in water quality as it has been well represented in the Ohio River of Ohio and Pennsylvania. These data support this hypothesis as we were able to confirm its presence in the Kanawha River proper from our lowest sampling local (locale 1) upstream to the mouth of the Elk River (locale 6) (e.g., rkms 9-59).

Additionally, we discovered suspected reproduction of Blue Catfish, an important game fish. Our data represented a Kanawha River drainage distributional record for this species. The WVDNR has been stocking Blue Catfish with fingerlings and adults as a put-and-take fishery with hopes of reestablishment. By finding young-of-year Blue Catfish it suggests there may be 
successful reproduction occurring within the Kanawha River in the Robert C. Byrd and to a lesser extent Winfield Pools. This is the first evidence of Blue Catfish reproduction in West Virginia waters. However, additional monitoring, fecundity, and more extensive population assessments of this species are needed to confirm if this population is naturally viable (Slipke et al. 2004; Love et al. 2017; Seibert et al. 2017).

The Ghost Shiner designated as a WV SGCN has likely been undersampled because most of the sampling in the Kanawha has been conducted with daytime electrofishing gear. This species is likely associated with deeper benthic habitats, as it has been observed by divers in the Ohio River swimming along the bottom at depths of $12.2 \mathrm{~m}$ (i.e., 40') during daylight hours, depths where they would likely not be captured by electrofishing (Rice and Zimmerman 2019). Because Ghost Shiners made up the largest catch relative abundance of all species $(n=24,933)$ and were the second most ubiquitous species of the 53 species collected, in this study it is recommended the Ghost Shiner be removed from the SGCN (i.e., from an S3 rank to S5).

One species that we initially hoped to observe in the mainstem Kanawha River was the Spotted Darter (Etheostoma maculatum), an SGCN in West Virginia, which has a patchy distribution across its range. We were unsuccessful at capturing this species during this study. This species likely is more of a habitat specialist than the closely related Bluebreast Darter, a species that was much more consistently distributed throughout the study area (Appendix figure 13). Osier and Welsh (2007) reported that this species Spotted Darters were often associated with unembedded large rocks $(>20 \mathrm{~cm})$ primarily in glide habitats at the head of riffles. Spotted Darters do not associate with silt covered substrate and use unembedded coarse substrates to adhere their eggs. This species lay relatively few eggs and provides more care (i.e., nest guarding) to their young, a trait of a K-selected organism (Ruble et al. 2016). My data are 
consistent with Honick et al. (2017) who were only able to document this species below one lock and dam installation in a non-wadeable environment. Of the three Nothonotus species reported by Honick et al. (2017), who documented the distribution extension of the Spotted Darter was less than that of the Tippecanoe and Bluebreast darters. My findings support the hypothesis that the Spotted Darter may be limited in its ability to recolonize areas of suitable habitat, because it is being restricted by the less favorable habitat of navigable river systems (i.e., higher water depths and levels of embeddedness of large rock). Also, the k-selected Spotted Darter may be limited in natural dispersal ability relative to the r-selected Tippecanoe and Bluebreast darters (Ruble et al. 2016; Zimmerman et al. 2017). Translocation and captive propagation or habitat enhancements may be viable options for managers looking to expand the range of the Spotted Darter.

Results of the canonical correspondence analysis indicate that water quality (i.e., water quality accounted for only $14.37 \%$ of explained variation) is likely not the most influential factor regulating the distribution of fishes in the Kanawha River. Conversely, factors contributing to the physical habitat of the system are likely the most influential factors to lotic fishes in this system (i.e., 75.20 of the constrained variation was attributed to physical predictors). Evidence of longitudinally differing habitats exists along the Kanawha River, likely governed by the distances from upstream and distances from downstream dams as well as distance the Kanawha River's confluence with the Ohio River (figure 4 CCA axis 1). Relative distance to mouth likely contributes to discharge (i.e., as you move further upstream there is less mean annual discharge). Dams have shown to have similar effects on fish assemblage composition and individual species' habitat use by being one of the major factors contributing to the construction of longitudinal 
substrate distribution as dominant fine substrates were positively correlated to distance from dams $(r=0.478, p$-value $=<0.0000)($ Freedman 2010; Pierce et al. 2013).

In addition to distance to the river mouth (rkm) and relative distance to upstream and downstream dams, islands also had a strong influence on fish assemblages. My results, consistent with previous studies, suggest that habitats around islands provide unique functional process zones (i.e., areas of unique hydro and fluvial geomorphic characteristics) that promote habitat heterogeneity (i.e., variations in depth, flow, substrate, and vegetation) necessary for the life history of certain fishes (i.e., Paddlefish, Sturgeon, Darters, Catfishes, and others) (Freedman et al. 2010; Freedman et al. 2014; Haupt and Phelps 2016; Love et al. 2017; Seibert et al. 2017). All percid species (i.e., darters) that were collected in adequate frequencies (e.g., $\geq 10 \%$ of all samples) were associated with islands in terms of their greatest relative abundance, suggesting that island areas should be of conservation focus. Island habitats provide "islands" of habitat heterogeneity within relatively homogenous navigable systems, where reduced access to respective floodplains results from channelization and altered natural flow regimes.

This study documented several state SGCN within lower Kanawha River proper that were previously undocumented (Table 7) through historic fish collection techniques (i.e., electrofishing, seining, rotenone, and gill nets) (Addair 1944; Cincotta et al. 1986; Stauffer et al., 1995; WVDNR unpublished data). Because a high likelihood exists that small-bodied benthic fishes will be undetected by traditional collection techniques in navigable river systems it may be necessary to include a standardized benthic trawling method for an accurate biological assessment of river fish species richness. Additionally, because our data demonstrated an association with island habitats and speciose benthic fish assemblages, as well as more robust populations of several benthic fishes, managers should consider including the sampling of island 
habitats to complement previously developed large river Indices of Biotic Integrity (Flotemersch et al., 2006). By adding benthic trawling to non-wadeable river health assessments, we may get a more holistic view of the fish assemblages and their interactions with the aquatic communities. 


\section{Literature Cited:}

Addair, J. 1944. The fishes of the Kanawha River system in West Virginia and some factors which influence their distribution. Doctoral Dissertation, Ohio State University, Columbus, Ohio.

Allan, J. D. 2004. Landscapes and riverscapes: the influence of land use on stream ecosystems. Annual Review of Ecology, Evolution, and Systematics 35:257-284.

Argent, D. G., and W. G. Kimmel. 2010. Influence of navigational lock and dam structures on adjacent fish communities in a major river system. River Research and Applications 27:1325-1333.

Argent, D. G., and W. G. Kimmel. 2014. Patterns of ichthyofaunal distribution and connectivity in navigable and free-flowing reaches of a major river system: The Allegheny River in Pennsylvania. River Research and Applications 30:631-638.

Burns A. D. 2007. Comparison of two electrofishing gears (backpack and parallel wires) and abundance of fishes of the upper Greenbrier River drainage. Master's Thesis. West Virginia University, Morgantown, West Virginia.

Barko, V. A., J. E. Garvey, J. W. Ridings, R. E. Colombo, R. C. Brooks, D. E. Ostendorf, D. P. Herzog, R. A. Hrabik, S. J. Tripp, and Q. E. Phelps. 2009. Seasonal comparison of catch cates and size structure using three gear types to sample sturgeon in the middle Mississippi River. North American Journal of Fisheries Management 29(5):1487-1495.

Blanchet, G. F., P. Legendre, and D. Borcard. 2008. Forward Selection of Explanatory Variables Ecology 89:2623-2632.

Borcard, D., F. Gillet, and P. Legendre. 2018. Numerical ecology with R. second edition, Springer, Cham, Switzerland.

Burkhead, N. M. 2012. Extinction rates in North American freshwater fishes, 1900-2010. BioScience 62:798-808.

Cincotta, D. A., R. L. Miles, M. E. Hoeft, and G. E. Lewis. 1986. Discovery of Noturus eleutherus, and Percina peltata, in West Virginia, with discussions of other additional and records of fishes. Brimleyana 12:101-121.

Cincotta, D. A., and S. A. Welsh. 2010. Discovery of Ammocrypta clara (Western Sand Darter) in the upper Ohio River of West Virginia. American Midland Naturalist 163:318-325.

Denoncourt, R. F., E. C. Raney, E. C. Raney, and J. R. Stauffer. 1975. A checklist of the fishes of West Virginia. Virginia Journal of Science 26:117-120.

Etnier, D. A. and W. C. Starnes. 1993. The fishes of Tennessee. The University Press, Knoxville.

Everett S. W., D. L. Scarnecchia, and L.F. Ryckman. 2004. Distribution and habitat use of Sturgeon Chubs (Macrhybopsis gelida) and Sicklefin Chubs (M. meeki) in the Missouri and Yellowstone Rivers, North Dakota. Hydrobiologia 527:183-193. 
Freedman, J. A., R. F. Carline, and J. R. Stauffer. 2013. Gravel dredging alters diversity and structure of riverine fish assemblages. Freshwater Biology 58:261-274.

Freedman, J. A, B. D. Lorson, R. B. Taylor, R. F. Carline, and J. R. Stauffer Jr. 2014. River of the dammed: longitudinal changes in fish assemblages in response to dams. Hydrobiologia 727:19-33.

Flotemersch, J. E., J. B. Stribling, and M. J. Paul. Concepts and approaches for the bioassessment of non-wadeable streams and rivers. EPA 600-R-06-127. US Environmental Protection Agency, Washington, DC.

Garvey, J. E., J. W. Ridings, R. A. Hrabik, D. P. Herzog, S. J. Tripp, J. W. Crites, Q. E. Phelps, and D. E. Ostendorf. 2010. Habitat use during early life history infers recovery needs for Shovelnose Sturgeon and Pallid Sturgeon in the middle Mississippi River. Transactions of the American Fisheries Society 139:1060-1068.

Goldsborough, E. L., and H. W. Clark. 1908. Fishes of West Virginia. Bulletin U.S. Bureau of Fisheries 27:29-39.

Haupt, K. J., and Q. E. Phelps. 2016. Mesohabitat associations in the Mississippi River basin: A long-term study on the catch rates and physical habitat associations of juvenile silver carp and two native planktivores. Aquatic Invasions 11:93-99.

Herzog, D. P., V. A. Barko, J. S. Scheibe, R. A. Hrabik, and D. E. Ostendorf. 2005. Efficacy of a benthic trawl for sampling small-bodied fishes in large river systems. North American Journal of Fisheries Management 25:594-603.

Herzog, D. P., D. E. Ostendorf, R. A. Hrabik, and V. A. Barko. 2009. The Mini-Missouri Trawl: a useful methodology for sampling small-bodied fishes in small and large river systems. Journal of Freshwater Ecology 24:103-108.

Hocutt, C. H., Jenkins, R. E., and J. R. Stauffer JR. 1986. Zoogeography of the fishes of the central Appalachians and central Atlantic coastal plain. Pages 161-211 in C. H. Hocutt and E. O. Wiley, editors. The zoogeography of North American freshwater fishes. John Wiley \& Sons, Inc., New York.

Honick, A. S., B. J. Zimmerman, J. R. Jr, Stauffer Jr, D. G. Argent, and B. A. Porter. 2017. Expanded distributions of three Etheostoma darters (subgenus Nothonotus) within the upper Ohio River watershed. Northeastern Naturalist 24:209-234

Koryak, M., Bonislawsky, P. S., Locy, D. D., and B. A. Porter. 2009. Typical channel-fish assemblage of the recovering lower Allegheny River navigation system, Pennsylvania, USA. Journal of Freshwater Ecology 24:509-517.

Jenkins, R. E., and N. A. Burkhead. 1994. Freshwater fishes of Virginia. American Fisheries Society, Bethesda, Maryland.

Legendre, P. and L. Legendre. 2012. Numerical ecology, third English edition. Elsevier, Boston.

Love, S. A., Phelps, Q. E., Tripp, S. J., and D. P. Herzog. 2016. The importance of shallow-low velocity habitats to juvenile fish in the middle Mississippi River. River Research Applications 33:1-7. 
McCune B. and J. B. Grace. 2002. Analysis of ecological communities. MjM Software Design, Gleneden Beach, Oregon.

Messenger, T. 1997. Water-quality assessment of the Kanawha-New River basin, West Virginia, and North Carolina - Review of water-quality literature through 1996. USGS WaterResource Investigations Report 97-4075:1-30.

Muller, R. Jr., and W. Pyron. 2010. Fish assemblages and substrates in the middle Wabash River, USA. Copeia 2010:47-53

Near, T. J., J. C. Porterfield, and L. M. Page. Evolution of Cytochrome b and the molecular systematics of Ammocrypta (Percidae: Etheostomatinae). Copeia 200:701-711.

Neebling, T. E., and M. C. Quist. 2008. Observations on the distribution and status of Western Sand Darter, Spotted Gar, and Skipjack Herring in Iowa Rivers. Journal of the Iowa Academy of Science 115:24-27.

Neebling, T. E. and M. C. Quist. 2010. Relationships between fish assemblages and habitat characteristics in Iowa's non-wadeable rivers. Fisheries Management and Ecology. 17:316385.

Neebling, T. E. and M. C. Quist. 2011. Comparison of boat electrofishing, trawling and seining for sampling fish assemblages in Iowa's nonwadeable rivers. North American Journal of Fisheries Management 31:390-402.

Nielsen, L. A., R. J. Sheehan, and D. J. Orth. 1986. Impacts of navigation on riverine fish production in the United States. Polskie Archiwum Hydrobiologii 33:277-294.

Niles, J. M., and K. J. Hartman. 2009. Larval fish use of dike structures on a navigable river, North American Journal of Fisheries Management 24:1035-1045.

Osier, E. A., and S. A. Welsh. 2007. Habitat Use of Etheostoma maculatum (Spotted Darter) in Elk River, West Virginia. Northeastern Naturalist 14:447-460.

Page, L. M. and B. M. Burr. 2011. Peterson Field Guide to Freshwater Fishes of North America North of Mexico. Houghton Mifflin Harcourt, New York.

Parks, T. P. 2013. Fish assemblages in Iowa's nonwadeable rivers: historic changes in assemblage structure and relationships with natural and anthropogenic environmental characteristics. M.S. Thesis. Iowa State University, Ames, Iowa.

Peck. J. E. 2016. Multivariate analysis for ecologist—step-by-step-second edition using PCORD v.7. MjM software. Gleneden Beach, Oregon.

Pflieger, W. L. 1971. A distributional study of Missouri fishes. Museum Material History Kansas Publication 20:225-570.

Pflieger, W. L. 1997. The fishes of Missouri. Missouri Department of Conservation, Jefferson City, Missouri.

Phelps, Q. E., S. J. Tripp, J. E. Garvey, D. P. Herzog, R. A. Hrabik, D. E. Ostendorf, J. W. Ridings, and J. W. Crites. 2011. 25-Juvenile Catfish Habitat Use in MMR. American 
Fisheries Society Symposium 77:535-543.

Poff, N. L., J. D. Allan, M. B. Bain, J. R. Karr, K. L. Prestegaard, B. D. Richter, R. E. Sparks, and J. C. Stromberg. 1997. The natural flow regime. BioScience 47:769-784.

Rice, D., and B. J. Zimmerman. 2019. A Naturalist's guide to the fishes of Ohio. Ohio Biological Survey, Columbus, Ohio.

R Core Team (2018). R: A language and environment for statistical computing. R Foundation for Statistical Computing. Vienna, Austria. URL https://www.R-project.org/.

Ruble, C. L., P. L. Rakes, J. R. Shute, and S. A. Welsh. 2016. Captive propagation, reproductive biology, and early life history of Etheostoma wapiti (Boulder Darter), E. vulneratum (Wounded Darter), and E. maculatum (Spotted Darter). Southeastern Naturalist 15:115126.

Seibert, K. L., J. R. Seibert, and Q. E. Phelps. 2017. Age-0 blue catfish habitat use and population demographics in the middle Mississippi River. Fisheries Management and Ecology 24:427-435.

Simons, T. P., and Wallus, R. 2004. Reproductive biology and early life history of fishes in the Ohio River drainage: Ictaluridae-Catfish and Madtoms: Volume 3. CRC Press. New York.

Simons, T. P., and Wallus, R. 2006. Reproductive biology and early life history of fishes in the Ohio River drainage.: Percidae_-Perch, Pikeperch, and Darters: Volume 4. CRC Press. New York.

Slipke, J. W., A. D. Martin, J. Pitlo, and M. J. Maceina. 2004. Use of the spawning potential ratio for the upper Mississippi River Channel Catfish fishery. North American Journal of Fisheries Management 22:1295-1300.

Smith, C. D., M. C. Quist, and R.S. Hardy. 2016. Fish assemblage structure and habitat associations in a large western river system. River Research and Applications 32:622-638.

Stauffer, J. R., B. M. Burr, C. H. Hocutt, and R. E. Jenkins. 1982. Checklist of the fishes of the central and northern Appalachian Mountains. Proceedings of the Biological Society of Washington. 95:27-47.

Stauffer, J. R., J. M. Boltz, and L. R. White. 1995. The Fishes of West Virginia. The Proceedings of the Academy of Natural Sciences of Philadelphia, Philadelphia, Pennsylvania.

Stauffer, J.R., R.W. Criswell, and D. P. Fischer. 2016. The Fishes of Pennsylvania. Cichlid Press, El Paso, TX.

Stewart, J. G., V. A. Barko, D. P. Herzog, D. B. Henry, J. W. Ridings, A. F. Kelly, and J. E. Wallace. 2005. New records of the Crystal Darter (Crystallaria asprella) in the middle Mississippi River. American Midland Naturalist 154:471-473.

Sparks, R. E., P. B. Bayley, S. L. Kohler, and L. L. Osborne. 1990. Disturbance and recovery of large floodplain rivers. Environmental Management 14:699-709.

Sparks, R. E. 1995. Need for ecosystem management of large river and their floodplains. BioScience 45:168-182. 
Thompson, P. A., S. A. Welsh, A. A. Rizzo, and D. M. Smith. 2017. Effect of substrate size on sympatric sand darter benthic habitat preferences. Journal of Freshwater Ecology 32:455465.

Thorp, J. H. 1992. Linkage between islands and benthos in the Ohio River, with implications for riverine management. Canadian Journal of Fisheries and Aquatic Sciences 49:1873-1882.

Thorp, J. H., M. C. Thoms, and M. D. Delong. 2006. The riverine ecosystem synthesis: biocomplexity in river networks across space and time. River Research Applications 22: 123-147.

Welsh, S. A., and R. M. Wood. 2008. Crystallaria cincotta, a new species of darter (Teleostei: Percidae) from the Elk River of the Ohio River drainage, West Virginia. Zootaxa (1680):62-68.

Wentworth, C. K. 1922. A scale of grade and class terms for clastic sediments. Journal of Geology 30:377-392.

WVDNR. 2015. State wildlife action plan. West Virginia Division of Natural Resources. Charleston, West Virginia. 


\section{Tables}

Table 1: Table containing the sampling locale names, respective pools, counties, and UTM coordinates of approximate centers of the area where sampling was conducted.

\begin{tabular}{|c|c|c|c|c|c|c|c|}
\hline $\begin{array}{l}\text { Local } \\
\text { Label }\end{array}$ & Local Site Name & Description & Pool & County & $\begin{array}{l}\text { UTM } \\
\text { Zone }\end{array}$ & $\begin{array}{c}\text { UTM } \\
\text { Easting }\end{array}$ & UTM Northing \\
\hline 1 & Tenmile Creek & $\begin{array}{l}\text { Mouth of Lower Nine Mile Creek to } \\
\text { mouth of Ten Mile Creek }\end{array}$ & Robert C Byrd & Mason & 17 & 413571 & 4292364 \\
\hline 2 & Hurricane Creek/Buffalo Creek & Mouth of Buffalo to Hurricane Creek & Robert C Byrd & Putnam & 17 & 417467 & 4265884 \\
\hline 3 & Pocatalico River & Mouth of Pocatalico River & Winfield & Putnam & 17 & 428699 & 4259012 \\
\hline 4 & Coal River & Mouth of Coal River & Winfield & Kanawha & 17 & 426548 & 4250054 \\
\hline 5 & Blaine Island & Around Blaine Island & Winfield & Kanawha & 17 & 440227 & 4247050 \\
\hline 6 & Elk River & Mouth of Elk River & Winfield & Kanawha & 17 & 443592 & 4245359 \\
\hline 7 & Scotts Island & Around Scotts Island & Marmet & Kanawha & 17 & 453739 & 4230394 \\
\hline 8 & Watsons Island & Around Watsons Island & Marmet & Kanawha & 17 & 459737 & 4229279 \\
\hline 9 & Wheeler Island & Around Wheeler Island & London & Fayette & 17 & 473611 & 4223544 \\
\hline
\end{tabular}

Table 3: Table containing habitat names, codes, and descriptions sampled.

\begin{tabular}{|c|c|c|}
\hline Habitats Sampled & Code & Description \\
\hline Main channel & MC & Not located within 30 meters of a bank normally associated with the navigation channel or thalweg \\
\hline Main channel border & MCB & Located within 30 meters of a main channel bank that is not an island \\
\hline $\begin{array}{l}\text { Island main channel } \\
\text { border }\end{array}$ & IMCB & $\begin{array}{l}\text { Located within 0-30 meters from the island bank into the main channel; between the head (first } 100 \text { meters) and toe (most } \\
\text { downstream } 100 \text { meters) of an island }\end{array}$ \\
\hline Island head & $\mathrm{IH}$ & Located within 0-30 meters from the island bank within the first upstream 100 meters of an island \\
\hline Island toe & IT & Located within 0-30 meters from the island bank within the downstream last 100 meters of an island \\
\hline $\begin{array}{l}\text { Island side channel } \\
\text { border }\end{array}$ & ISCB & $\begin{array}{l}\text { Located within 0-30 meters from the island bank into the side channel; between the head (first } 100 \text { meters) and toe (most } \\
\text { downstream } 100 \text { meters) of an island }\end{array}$ \\
\hline Side channel & $\mathrm{SC}$ & Secondary channel flowing around an island that is not within 30 meters from a bank (not main channel) \\
\hline Side channel border & SCB & Area of the river extending up to 30 meters from the side channel bank (non-island) \\
\hline Tributary & TRIB & $\begin{array}{l}\text { Area located within } 30 \text { meters of the bank or confluence of a tributary; extending } 100 \text { meters upstream and downstream in the } \\
\text { main river (Kanawha) }\end{array}$ \\
\hline
\end{tabular}


Table 3: Table consisting of the environmental covariates collected for each sample (i.e., individual trawl haul).

\begin{tabular}{|c|c|c|c|}
\hline Environmental Covariates & Units & Equipment & Observation Description \\
\hline Air temperature & Degrees Celcius $(0.1 \mathrm{C})$ & YSI Pro Plus & beginning of haul \\
\hline Bottom water temperature & Degrees Celcius (0.1C) & YSI Pro Plus & beginning of haul \\
\hline Bottom water $\mathrm{pH}$ & $\begin{array}{l}\text { Moles per liter }(0.01 \mathrm{pH}) \\
\text { Microseimens/CMC }(0.1\end{array}$ & YSI Pro Plus & beginning of haul \\
\hline Bottom specific conductivity & $\left.\mu \mathrm{S} / \mathrm{CM} @ 23^{\circ} \mathrm{C}\right)$ & YSI Pro Plus & beginning of haul \\
\hline Bottom ambient conductivity & Microseimens/CM (0.1 $\mu \mathrm{S} / \mathrm{CM})$ & YSI Pro Plus & beginning of haul \\
\hline Bottom total dissolved solids & Milligrams per liter (0.01 TDS mg/l) & YSI Pro Plus & beginning of haul \\
\hline Bottom dissolved oxygen percent & $\% \mathrm{O} 2$ saturation $(0.1 \%)$ & YSI Pro Plus & beginning of haul \\
\hline Bottom dissolved oxygen mg/L & $\mathrm{mg} \mathrm{O} / \mathrm{L}(0.1 \mathrm{mg} / \mathrm{L})$ & YSI Pro Plus & beginning of haul \\
\hline Average water depth & meters $(0.1 \mathrm{~m})$ & Lowrance sonar & entire haul \\
\hline Bottom water velocity & meters/second $(0.01 \mathrm{~m} / \mathrm{s})$ & OTT mf pro digital velocity meter & beginning and end of haul \\
\hline Dominate substrate class & Modified Wentworth Scale (Table 3) & Ponar Grab and Sounding weight & beginning and end of haul \\
\hline Secchi depth (Turbidity) & Centimeters $(1.0 \mathrm{~cm})$ & Secci disk & beginning and end of haul \\
\hline Distance to nearest bank & Meters $(0.5 \mathrm{~m})$ & Range finder & beginning and end of haul \\
\hline Distance to mouth & River kilometers (Rkm) & GPS & center of haul \\
\hline Distance to nearest upstream dam & kilometers $(\mathrm{km})$ & GPS & center of haul \\
\hline Distance to nearest downstream dam & kilometers $(\mathrm{km})$ & GPS & center of haul \\
\hline
\end{tabular}


Table 5: Table containing mean covariate values and standard deviations (i.e., mean $( \pm \mathrm{SD})$ ) by habitat type sampled.

\begin{tabular}{|c|c|c|c|c|c|}
\hline Environmental Covariate & MC & MCB & SC & SCB & TRIB \\
\hline Temperature $\mathrm{C}^{\circ}$ & $24.7( \pm 1.81)$ & $25.1( \pm 1.98)$ & $25.0( \pm 1.86)$ & $24.4( \pm 1.57)$ & $24.9( \pm 2.51)$ \\
\hline $\mathrm{pH}$ & $7.76( \pm 0.38)$ & $7.88( \pm 0.36)$ & $7.69( \pm 0.33)$ & $7.72( \pm 0.30)$ & $7.89( \pm 0.39)$ \\
\hline Spec. Cond (uS/cm) & $250( \pm 131.80)$ & $234( \pm 77.17)$ & $154( \pm 16.58)$ & $145( \pm 10.29)$ & $319( \pm 267.09)$ \\
\hline TDS (mg/l) & $163( \pm 85.64)$ & $153( \pm 51.79)$ & $100( \pm 10.81)$ & $94( \pm 6.70)$ & $209( \pm 172.70)$ \\
\hline Dissolved Oxygen (mg/l) & $7.42( \pm 0.78)$ & $7.70( \pm 1.10)$ & $7.62( \pm 0.64)$ & $7.82( \pm 1.94)$ & $7.48( \pm 1.28)$ \\
\hline Water Depth $(\mathrm{m})$ & $6.21( \pm 1.68)$ & $3.11( \pm 1.11)$ & $5.00( \pm 0.98)$ & $3.92( \pm 1.30)$ & $3.08( \pm 1.72)$ \\
\hline Bottom Water Velocity (m/s) & $0.089( \pm 0.07)$ & $0.042( \pm 0.03)$ & $0.130( \pm 0.07)$ & $0.081( \pm 0.05)$ & $0.046( \pm 0.03)$ \\
\hline Secchi Depth $(\mathrm{cm})$ & $110( \pm 28.20)$ & $102( \pm 32.22)$ & $108( \pm 33.11)$ & $104( \pm 33.05)$ & $96( \pm 31.79)$ \\
\hline Dist. to Bank (m) & $98.5( \pm 20.79)$ & $14.6( \pm 5.18)$ & $46.7( \pm 15.76)$ & $14.8( \pm 4.73)$ & $21.1( \pm 9.30)$ \\
\hline Dist. to mouth $(\mathrm{km})$ & $75.98( \pm 35.20)$ & $74.19( \pm 36.20)$ & $115.98( \pm 19.18)$ & $115.93( \pm 19.06)$ & $74.63( \pm 36.54)$ \\
\hline Dist. to Upstream Dam & $23.54( \pm 14.67)$ & $23.91( \pm 14.55)$ & $14.67( \pm 4.68)$ & $14.73( \pm 4.55)$ & $23.50( \pm 14.82)$ \\
\hline \multirow[t]{2}{*}{ Dist. to Downstream Dam } & $30.23( \pm 20.30)$ & $30.36( \pm 19.98)$ & $15.96( \pm 13.83)$ & $15.91( \pm 13.92)$ & $30.80( \pm 19.62)$ \\
\hline & IH & IMCB & ISCB & IT & \\
\hline Temperature $\mathrm{C}^{\circ}$ & $25.4( \pm 2.08)$ & $25.6( \pm 1.92)$ & $24.9( \pm 1.43)$ & $24.5( \pm 1.71)$ & \\
\hline $\mathrm{pH}$ & $7.53( \pm 0.31)$ & $7.77( \pm 0.22)$ & $7.73( \pm 0.31)$ & $7.61( \pm 0.30)$ & \\
\hline Spec. Cond (uS/cm) & $151( \pm 20.23)$ & $156( \pm 22.61)$ & $151( \pm 17.73)$ & $151( \pm 18.04)$ & \\
\hline TDS (mg/l) & $98( \pm 13.19)$ & $102( \pm 14.73)$ & $98( \pm 11.55)$ & $101( \pm 17.94)$ & \\
\hline Dissolved Oxygen (mg/l) & $7.20( \pm 1.54)$ & $7.37( \pm 0.89)$ & $8.14( \pm 0.27)$ & $8.29( \pm 0.87)$ & \\
\hline Water Depth (m) & $2.58( \pm 1.70)$ & $3.95( \pm 1.73)$ & $4.24( \pm 1.13)$ & $3.62( \pm 1.49)$ & \\
\hline Bottom Water Velocity (m/s) & $0.142( \pm 0.08)$ & $0.074( \pm 0.03)$ & $0.080( \pm 0.05)$ & $0.060( \pm 0.05)$ & \\
\hline Secchi Depth $(\mathrm{cm})$ & $90( \pm 40.92)$ & $137( \pm 22.20)$ & $112( \pm 18.69)$ & $89( \pm 38.77)$ & \\
\hline Dist. to Bank (m) & $15.3( \pm 4.79)$ & $18.4( \pm 5.92)$ & $16.6( \pm 5.29)$ & $38.1( \pm 27.49)$ & \\
\hline Dist. to mouth (km) & $116.40( \pm 19.00)$ & $115.90( \pm 19.31)$ & $115.96( \pm 19.05)$ & $115.31( \pm 19.36)$ & \\
\hline Dist. to Upstream Dam & $14.26( \pm 4.49)$ & $14.76( \pm 4.75)$ & $14.70( \pm 4.54)$ & $15.34( \pm 4.78)$ & \\
\hline Dist. to Downstream Dam & $16.37( \pm 14.10)$ & $15.88( \pm 13.71)$ & $15.94( \pm 14.01)$ & $15.29( \pm 13.52)$ & \\
\hline
\end{tabular}


Table 6: Table listing the names, total abundance, and SGCN status of the species of observed fishes.

\begin{tabular}{|c|c|c|c|c|}
\hline Count & Species Name & Common Name & Abundance & SGCN \\
\hline 1 & Ambloplites rupestris & Rock Bass & 40 & \\
\hline 2 & Ammocrypta clara & Western Sand Darter & 16 & $\mathrm{Y}$ \\
\hline 3 & Ammocrypta pellucida & Eastern Sand Darter & 183 & $\mathrm{Y}$ \\
\hline 4 & Aplodinotus grunniens & Freshwater Drum & 2414 & \\
\hline 5 & Carpiodes carpio & River Carpsucker & 2 & $\mathrm{Y}$ \\
\hline 6 & Cyprinella spiloptera & Spotfin Shiner & 27 & \\
\hline 7 & Dorosoma cepedianum & Gizzard Shad & 92 & \\
\hline 8 & Erimystax dissimilis & Streamline Chub & 32 & Y \\
\hline 9 & Etheostoma blennioides & Greenside Darter & 1 & \\
\hline 10 & Etheostoma camurum & Bluebreast Darter & 292 & \\
\hline 11 & Etheostoma nigrum & Johnny Darter & 52 & \\
\hline 12 & Etheostoma tippecanoe & Tippecanoe Darter & 21 & $\mathrm{Y}$ \\
\hline 13 & Etheostoma zonale & Banded Darter & 4 & \\
\hline 14 & Hybopsis amblops & Bigeye Chub & 1281 & \\
\hline 15 & Hypentelium nigricans & Northern Hog Sucker & 1 & \\
\hline 16 & Ictalurus furcatus & Blue Catfish & 32 & \\
\hline 17 & Ictalurus punctatus & Channel Catfish & 506 & \\
\hline 18 & Ichthyomyzon bdellium & Ohio Lamprey & 1 & Y \\
\hline 19 & Lepisosteus osseus & Longnose Gar & 1 & \\
\hline 20 & Lepomis cyanellus & Green Sunfish & 2 & \\
\hline 21 & Lepomis gulosus & Warmouth & 1 & $\mathrm{Y}$ \\
\hline 22 & Lepomis humilis & Orangespotted Sunfish & 12 & Y \\
\hline 23 & Lepomis macrochirus & Bluegill & 626 & \\
\hline 24 & Lepomis megalotis & Longear Sunfish & 400 & \\
\hline 25 & Macrhybopsis hyostoma & Shoal Chub & 100 & Y \\
\hline 26 & Macrhybopsis storeriana & Silver Chub & 27 & Y \\
\hline 27 & Micropterus dolomieu & Smallmouth Bass & 76 & \\
\hline 28 & Micropterus punctulatus & Spotted Bass & 22 & \\
\hline 29 & Moxostoma anisurum & Silver Redhorse & 1 & \\
\hline 30 & Moxostoma breviceps & Smallmouth Redhorse & 1 & \\
\hline 31 & Moxostoma duquesnei & Black Redhorse & 1 & \\
\hline 32 & Moxostoma erythrurum & Golden Redhorse & 23 & \\
\hline 33 & Notropis atherinoides & Emerald Shiner & 152 & \\
\hline 34 & Notropis buchanani & Ghost Shiner & 24933 & $\mathrm{Y}$ \\
\hline 35 & Notropis hudsonius & Spottail Shiner & 25 & \\
\hline 36 & Notropis stramineus & Sand Shiner & 3 & \\
\hline 37 & Notropis volucellus & Mimic Shiner & 3379 & \\
\hline
\end{tabular}


Table 6 continued: Table listing the names, total abundance, and SGCN status of observed fishes.

\begin{tabular}{cllcc}
\hline Count & Species Name & Common Name & Abundance & SGCN \\
\hline 38 & Notropis wickliffi & Channel Shiner & 12565 & \\
39 & Noturus stigmosus & Northern Madtom & 2 & Y \\
40 & Percina caprodes & Logperch & 19 & \\
41 & Percina copelandi & Channel Darter & 81 & Y \\
42 & Percina evides & Gilt Darter & 2 & Y \\
43 & Percina macrocephala & Longhead Darter & 7 & Y \\
44 & Percina phoxocephala & Slenderhead Darter & 15 & Y \\
45 & Percina sciera & Dusky Darter & 2 & Y \\
46 & Percina shumardi & River Darter & 7 & Y \\
47 & Percopsis omiscomaycus & Trout-Perch & 1 & \\
48 & Pimephales notatus & Bluntnose Minnow & 356 & Y \\
49 & Pimephales vigilax & Bullhead Minnow & 1268 & \\
50 & Pomoxis annularis & White Crappie & 6 & 1 \\
51 & Pomoxis nigromaculatus & Black Crappie & 3 & \\
52 & Pylodictis olivaris & Flathead Catfish & 1 & \\
53 & Sander canadensis & Sauger & $\mathbf{4 9 1 1 8}$ & \\
\hline
\end{tabular}


Table 7: Benthic SGCNs that were confirmed to be occupying the navigable Kanawha River.

\begin{tabular}{clll}
\hline Count & Family & Scientific Name & Common Name \\
\hline 1 & Petromyzontiade & Ichthyomyzon bdellium & Ohio Lamprey \\
2 & Catostomidae & Carpiodes carpio & River Carpsucker \\
3 & Cyprinidae & Erimystax dissimilis & Streamline Chub \\
4 & Cyprinidae & Macrhybopsis hyostoma & Shoal Chub \\
5 & Cyprinidae & Macrhybopsis storeriana & Silver Chub \\
6 & Cyprinidae & Notropis buchanani & Ghost Shiner \\
7 & Cyprinidae & Pimephales vigilax & Bullhead Minnow \\
8 & Ictaluridae & Noturus stigmosus & Northern Madtom \\
9 & Percidae & Ammocrypta clara & Western Sand Darter \\
10 & Percidae & Ammocrypta pellucida & Eastern Sand Darter \\
11 & Percidae & Etheostoma tippecanoe & Tippecanoe Darter \\
12 & Percidae & Percina copelandi & Channel Darter \\
13 & Percidae & Percina evides & Gilt Darter \\
14 & Percidae & Percina macrocephala & Longhead Darter \\
15 & Percidae & Percina phoxocephala & Slenderhead Darter \\
16 & Percidae & Percina sciera & Dusky Darter \\
17 & Percidae & Percina shumardi & River Darter \\
\hline
\end{tabular}

Table 8 : Species collected representing new distribution and species richness records for the Kanawha River.

\begin{tabular}{cllcc}
\hline Count & Common Name & Species Name & Abundance & SGCN \\
\hline 1 & Western Sand Darter & Ammocrypta clara & 16 & Y \\
2 & Tippecanoe Darter & Etheostoma tippecanoe & 21 & Y \\
3 & Blue Catfish & Ictalurus furcatus & 32 & - \\
4 & Gilt Darter & Percina evides & 2 & Y \\
5 & Longhead Darter & Percina macrocephala & 7 & Y \\
6 & Slenderhead Darter & Percina phoxocephala & 15 & Y \\
7 & River Darter & Percina shumardi & 7 & Y \\
\hline
\end{tabular}


Table 9: Candidate environmental predictor variables used in forward model selection procedure.

\begin{tabular}{|c|c|c|c|c|}
\hline Group & $\begin{array}{c}\text { Environmental } \\
\text { Covariates }\end{array}$ & Units / Description & Variable Type & $\begin{array}{l}\text { Included in } \\
\text { final model }\end{array}$ \\
\hline $\mathrm{W}$ & $\begin{array}{l}\text { Bottom water } \\
\text { temperature }\end{array}$ & Degrees Celsius (0.1C) & Continuous & $\mathrm{Y}$ \\
\hline $\mathrm{W}$ & $\begin{array}{l}\text { Bottom water } \\
\mathrm{pH}\end{array}$ & Moles per liter $(0.01 \mathrm{pH})$ & Continuous & $\mathrm{Y}$ \\
\hline $\mathrm{W}$ & $\begin{array}{l}\text { Bottom specific } \\
\text { conductivity }\end{array}$ & Microseimens/CMC $\left(0.1 \mu \mathrm{S} / \mathrm{CM} @ 23^{\circ} \mathrm{C}\right)$ & Continuous & $\mathrm{N}$ \\
\hline $\mathrm{W}$ & $\begin{array}{l}\text { Bottom total } \\
\text { dissolved solids }\end{array}$ & Milligrams per liter (0.01 TDS mg/l) & Continuous & $\mathrm{N}$ \\
\hline $\mathrm{W}$ & $\begin{array}{l}\text { Bottom } \\
\text { dissolved } \\
\text { oxygen } \mathrm{mg} / \mathrm{L}\end{array}$ & $\mathrm{mg} \mathrm{O}_{2} / \mathrm{L}(0.1 \mathrm{mg} / \mathrm{L})$ & Continuous & $\mathrm{Y}$ \\
\hline $\mathrm{W}$ & $\begin{array}{l}\text { Secchi depth } \\
\text { (Turbidity) }\end{array}$ & Centimeters $(1.0 \mathrm{~cm})$ & Continuous & Y \\
\hline $\mathrm{P}$ & $\begin{array}{l}\text { Average water } \\
\text { depth }\end{array}$ & meters $(0.1 \mathrm{~m})$ & Continuous & Y \\
\hline $\mathrm{P}$ & $\begin{array}{l}\text { Bottom water } \\
\text { velocity }\end{array}$ & meters/second $(0.01 \mathrm{~m} / \mathrm{s})$ & Continuous & $\mathrm{Y}$ \\
\hline $\mathrm{P}$ & $\begin{array}{l}\text { Distance to } \\
\text { nearest bank }\end{array}$ & meters $(0.5 \mathrm{~m})$ & Continuous & $\mathrm{N}$ \\
\hline $\mathrm{P}$ & $\begin{array}{l}\text { Distance to } \\
\text { mouth }\end{array}$ & river kilometers (rkm) & Continuous & Y \\
\hline $\mathrm{P}$ & $\begin{array}{l}\text { Distance to } \\
\text { nearest } \\
\text { upstream dam }\end{array}$ & kilometers $(\mathrm{km})$ & Continuous & $\mathrm{Y}$ \\
\hline $\mathrm{P}$ & $\begin{array}{l}\text { Distance to } \\
\text { nearest } \\
\text { downstream } \\
\text { dam }\end{array}$ & kilometers $(\mathrm{km})$ & Continuous & $\mathrm{Y}$ \\
\hline $\mathrm{P}$ & $\begin{array}{l}\text { Main channel } \\
\text { habitat }\end{array}$ & Table 2 & Categorical & $\mathrm{Y}$ \\
\hline $\mathrm{P}$ & $\begin{array}{l}\text { Main channel } \\
\text { border habitat }\end{array}$ & Table 2 & Categorical & $\mathrm{N}$ \\
\hline $\mathrm{P}$ & Island head & Table 2 & Categorical & $\mathrm{Y}$ \\
\hline $\mathrm{P}$ & Island toe & Table 2 & Categorical & $\mathrm{Y}$ \\
\hline $\mathrm{P}$ & $\begin{array}{l}\text { Island main } \\
\text { channel border }\end{array}$ & Table 2 & Categorical & $\mathrm{Y}$ \\
\hline $\mathrm{P}$ & $\begin{array}{l}\text { Island side } \\
\text { channel border }\end{array}$ & Table 2 & Categorical & $\mathrm{Y}$ \\
\hline $\mathrm{P}$ & Side channel & Table 2 & Categorical & $\mathrm{Y}$ \\
\hline $\mathrm{P}$ & $\begin{array}{l}\text { Side channel } \\
\text { border }\end{array}$ & Table 2 & Categorical & $\mathrm{Y}$ \\
\hline $\mathrm{P}$ & Tributary & Table 2 & Categorical & $\mathrm{N}$ \\
\hline $\mathrm{P}$ & $\begin{array}{l}\text { Fine substrate } \\
\text { class }\end{array}$ & $\begin{array}{l}\text { Sample dominantly consisted of (sand, silt, or fine } \\
\text { gravel classes) }\end{array}$ & Categorical & $\mathrm{N}$ \\
\hline $\mathrm{P}$ & $\begin{array}{l}\text { Coarse } \\
\text { substrate class }\end{array}$ & $\begin{array}{l}\text { Sample dominantly consisted of (coarse gravel or } \\
\text { cobble bolder classes) }\end{array}$ & Categorical & $\mathrm{N}$ \\
\hline $\mathrm{P}$ & $\begin{array}{l}\text { Bedrock } \\
\text { substrate class }\end{array}$ & Sample dominantly consisted of (bedrock class) & Categorical & $\mathrm{N}$ \\
\hline $\mathrm{P}$ & $\begin{array}{l}\text { COM substrate } \\
\text { class }\end{array}$ & Sample dominantly consisted of (COM class) & Categorical & $\mathrm{N}$ \\
\hline $\mathrm{P}$ & $\begin{array}{l}\text { Presence of } \\
\text { sand }\end{array}$ & $>\%$ sand contained in sample & Categorical & $\mathrm{N}$ \\
\hline
\end{tabular}


Table 10: Table containing the species names and species code used in CCA analysis. Codes correspond to Figures 3, 4, and 5.

\begin{tabular}{clll}
\hline Count & Species Name & CCA Species Code & Common Name \\
\hline 1 & Ammocrypta pellucida & AMPE & Eastern Sand Darter \\
2 & Aplodinotus grunniens & APGR & Freshwater Drum \\
3 & Etheostoma camurum & ETCA & Bluebreast Darter \\
4 & Etheostoma nigrum & ETNI & Johnny Darter \\
5 & Hybopsis amblops & HYAM & Bigeye Chub \\
6 & Ictalurus punctatus & ICPU & Channel Catfish \\
7 & Lepomis macrochirus & LEMA & Bluegill \\
8 & Lepomis megalotis & LEME & Longear Sunfish \\
9 & Macrhybopsis hyostoma & MAHY & Shoal Chub \\
10 & Micropterus dolomieu & MIDO & Smallmouth Bass \\
11 & Notropis buchanani & NOBU & Ghost Shiner \\
12 & Notropis volucellus & NOVO & Mimic Shiner \\
13 & Notropis wickliffi & NOWI & Channel Shiner \\
14 & Percina copelandi & PECO & Channel Darter \\
15 & Pimephales notatus & PINO & Bluntnose Minnow \\
16 & Pimephales vigilax & PIVI & Bullhead Minnow \\
\hline
\end{tabular}


Figures

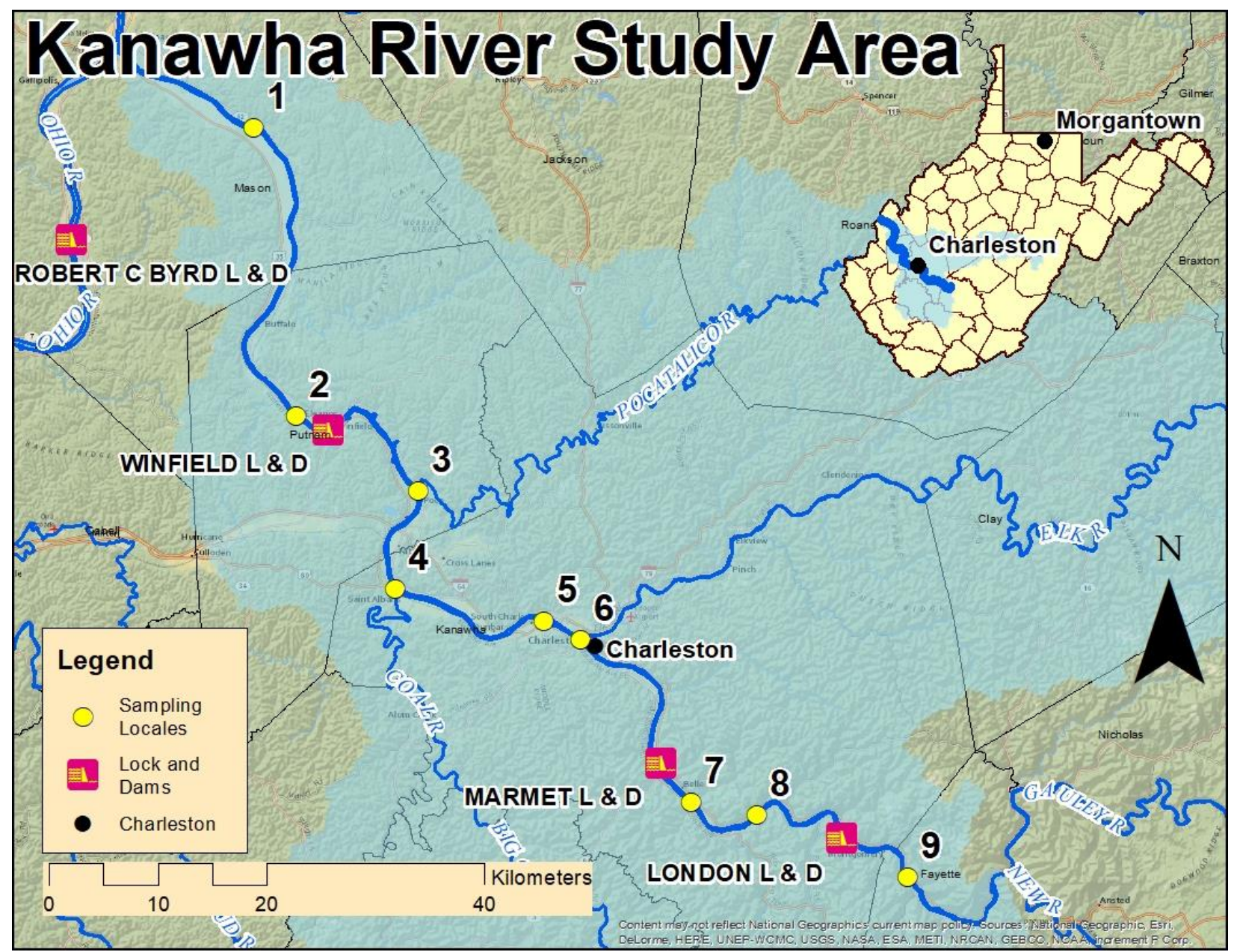

Figure 1: Map depicting the study area (Kanawha River) with sampling locales labeled 1-9 from Table 1 (e.g., 1. Tenmile Creek, 2. Hurricane Creek / Buffalo Creek, 3. Pocatalico River, 4. Coal River, 5. Blaine Island, 6. Elk River, 7. Scotts Island, 8. Watsons Island, and 9.Wheeler Island). 


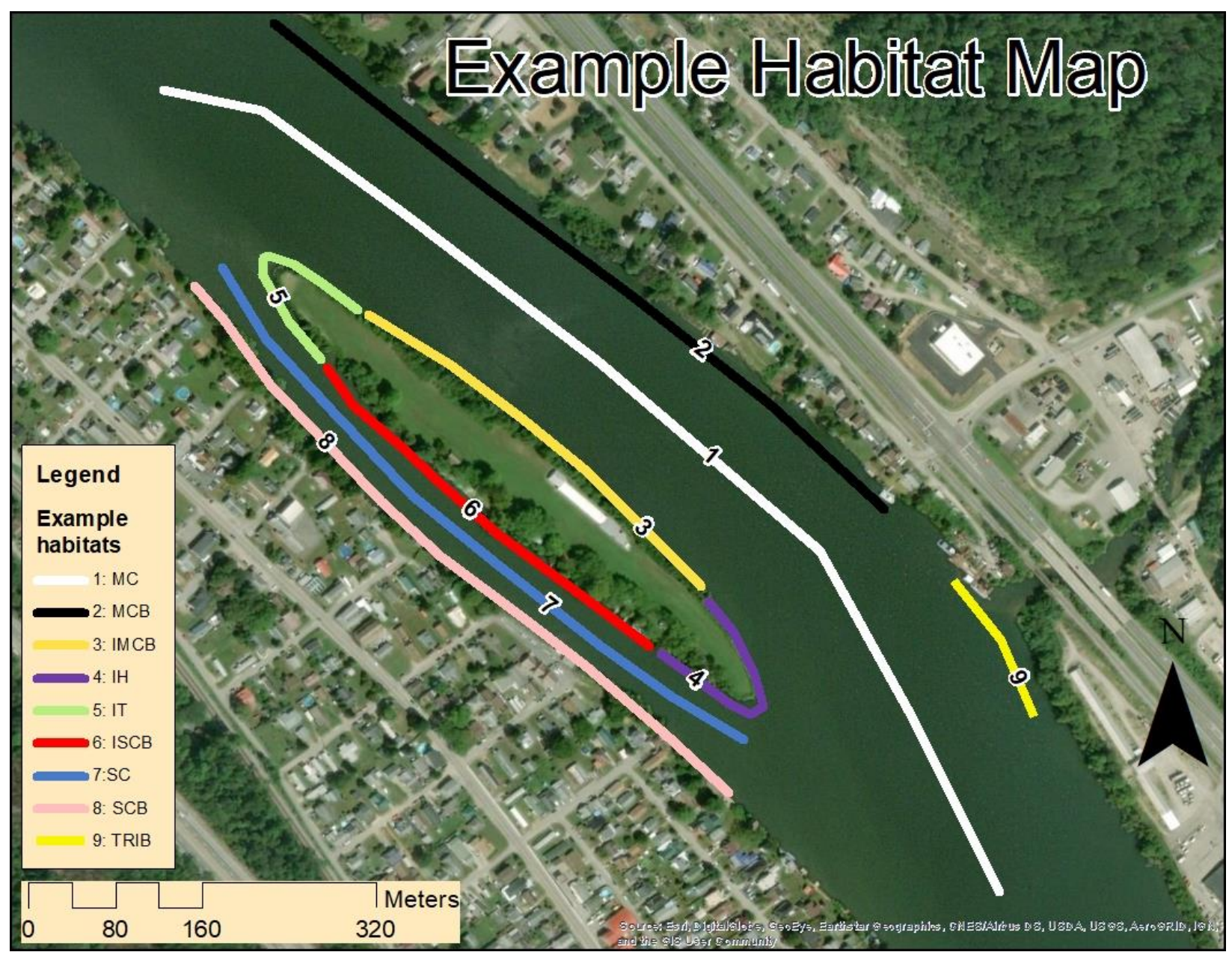

Figure 2: Map of various habitats sampled consisting of: 1. Main Channel (MC), 2. Main Channel Border (MCB), 3. Island Main Channel Border, 4. Island Head (IH), 5. Island Toe (IT), 6. Island Side Channel Border (ISCB), 7. Side Channel, 8. Island Side Channel Border (ISCB), and 9. Tributary (TRIB). Corresponding written description listed in table 2. 


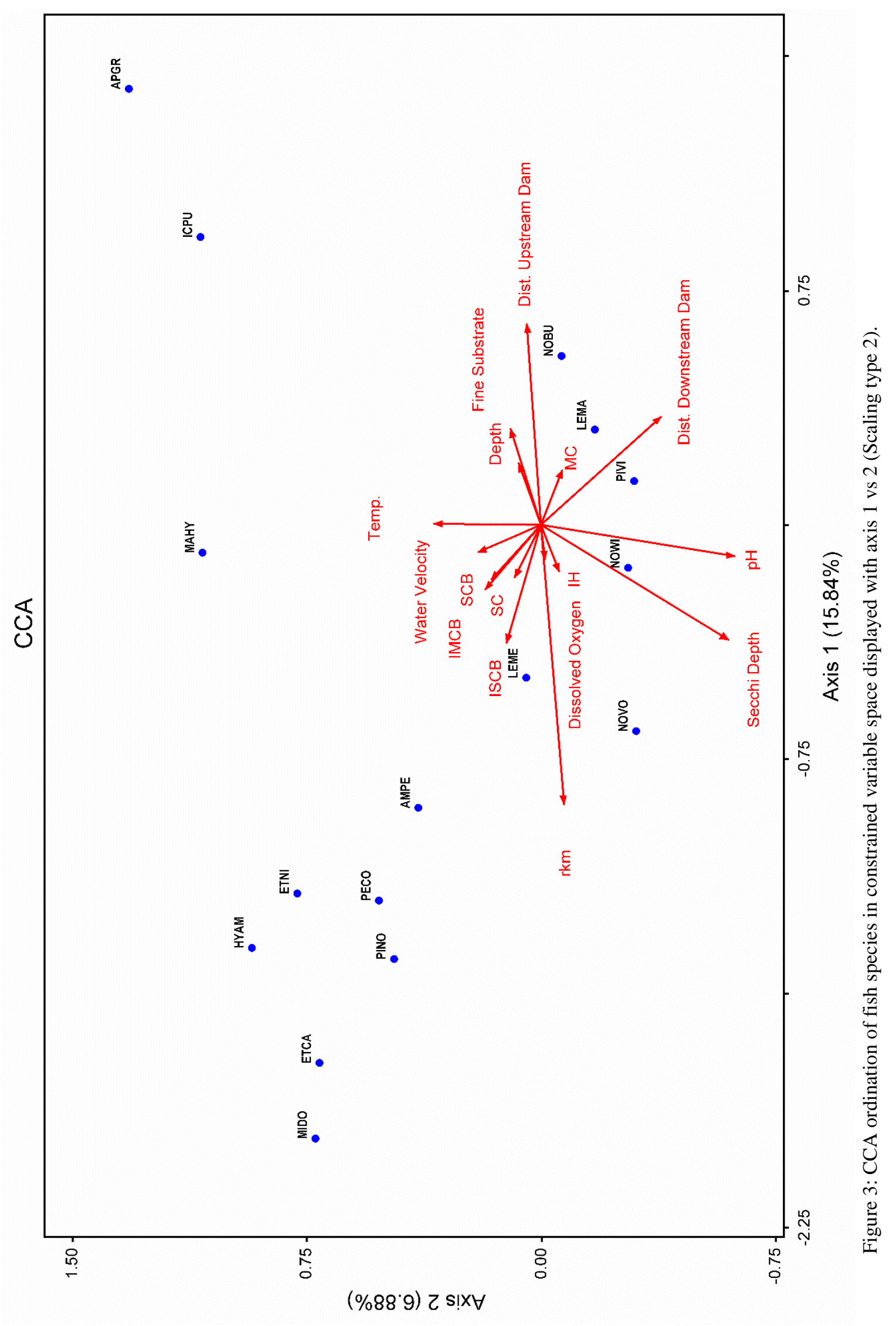




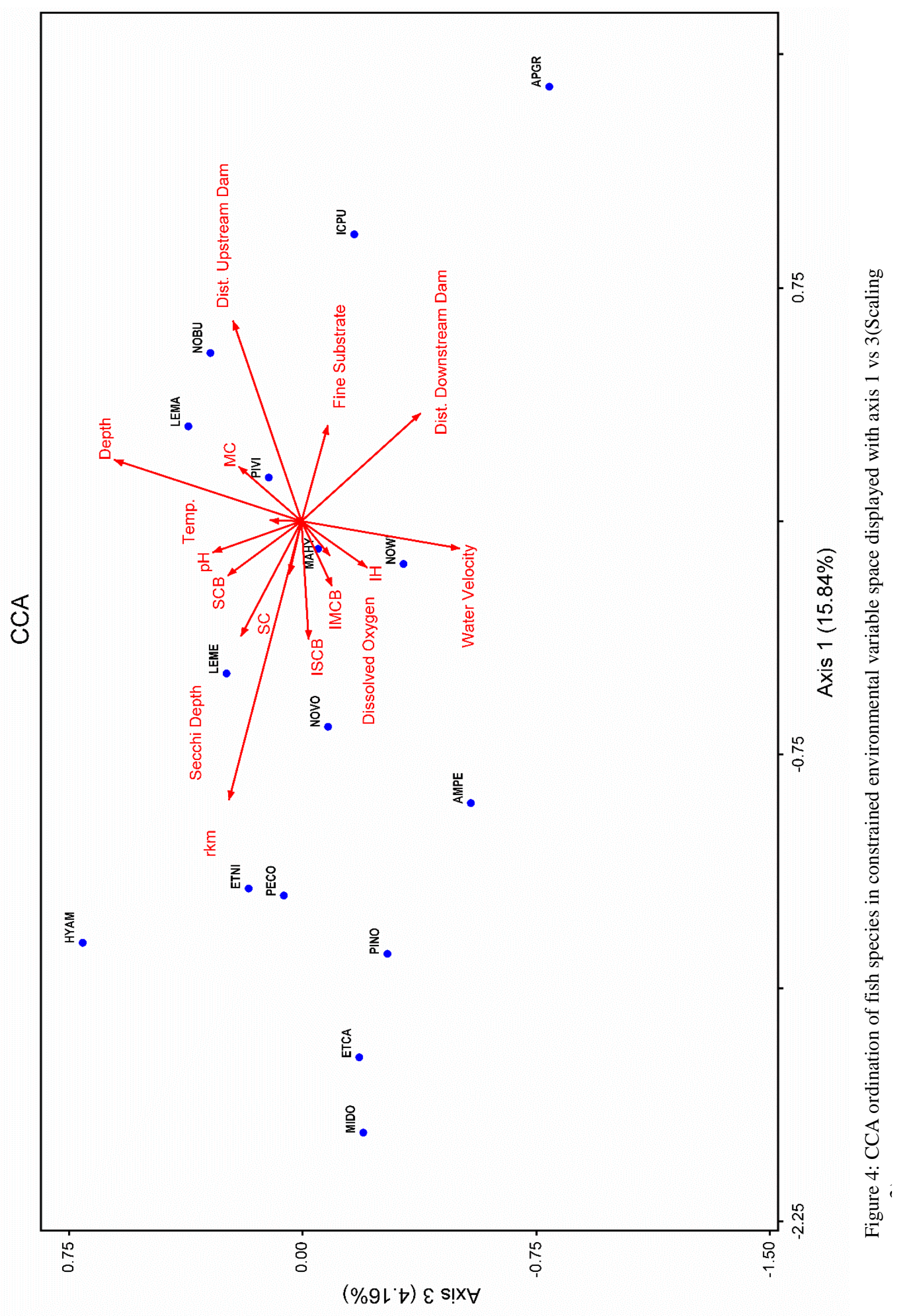




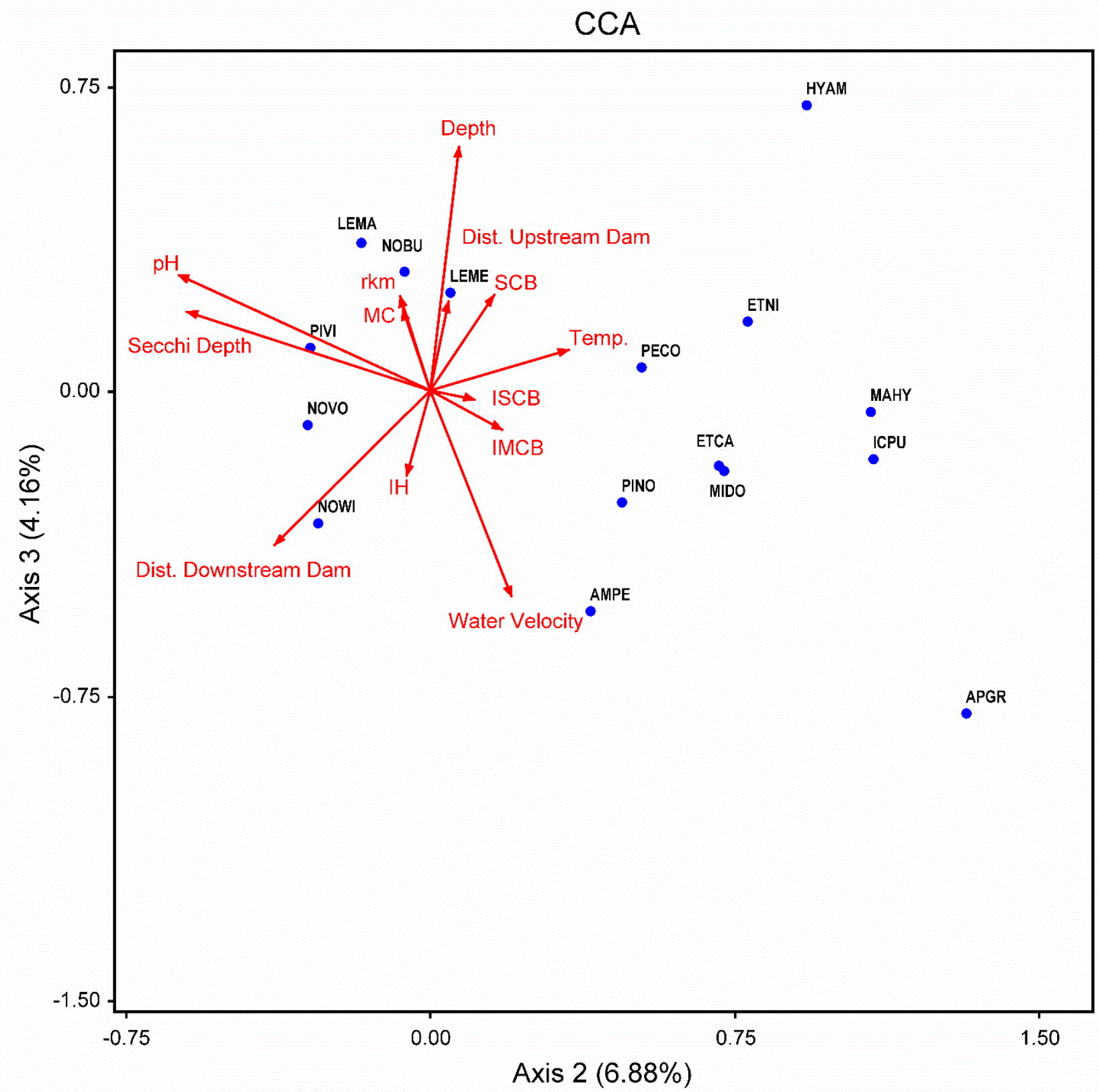

Figure 5: CCA ordination of fish species in constrained environmental variable space displayed with axis 2 vs 3 (Scaling type 2). 


\section{Appendix 1}

Tables

Table 1: Table containing the species for which Kanawha River distributions are provided in Appendix 1 (Figures 1-20) and whether they are a species of greatest need status (SGCN).

\begin{tabular}{cllc}
\hline Figure Number & \multicolumn{1}{c}{ Species Name } & \multicolumn{1}{c}{ Common Name } & $\begin{array}{c}\text { SGCN } \\
(\mathbf{Y} / \mathbf{N})\end{array}$ \\
\hline 1 & Erimystax dissimilis & Streamline Chub & Y \\
2 & Hybopsis amblops & Bigeye Chub & $\mathrm{N}$ \\
3 & Macrhybopsis hyostoma & Shoal Chub & $\mathrm{Y}$ \\
4 & Macrhybopsis storeriana & Silver Chub & $\mathrm{Y}$ \\
5 & Notropis buchanani & Ghost Shiner & $\mathrm{Y}$ \\
6 & Pimephales vigilax & Bullhead Minnow & $\mathrm{Y}$ \\
7 & Ictalurus furcatus & Blue Catfish & $\mathrm{Y}$ \\
8 & Ictalurus punctatus & Channel Catfish & $\mathrm{N}$ \\
9 & Lepomis humilis & Orangespotted Sunfish & $\mathrm{Y}$ \\
10 & Noturus stigmosus & Northern Madtom & $\mathrm{Y}$ \\
11 & Ammocrypta clara & Western Sand Darter & $\mathrm{Y}$ \\
12 & Ammocrypta pellucida & Eastern Sand Darter & $\mathrm{Y}$ \\
13 & Etheostoma camurum & Bluebreast Darter & $\mathrm{Y}$ \\
14 & Etheostoma tippecanoe & Tippecanoe Darter & $\mathrm{Y}$ \\
15 & Percina copelandi & Channel Darter & $\mathrm{Y}$ \\
16 & Percina evides & Gilt Darter & $\mathrm{Y}$ \\
17 & Percina macrocephala & Longhead Darter & $\mathrm{Y}$ \\
18 & Percina phoxocephala & Slenderhead Darter & $\mathrm{Y}$ \\
19 & Percina sciera & Dusky Darter & $\mathrm{Y}$ \\
20 & Percina shumardi & River Darter & $\mathrm{Y}$ \\
\hline
\end{tabular}




\section{Appendix 2}

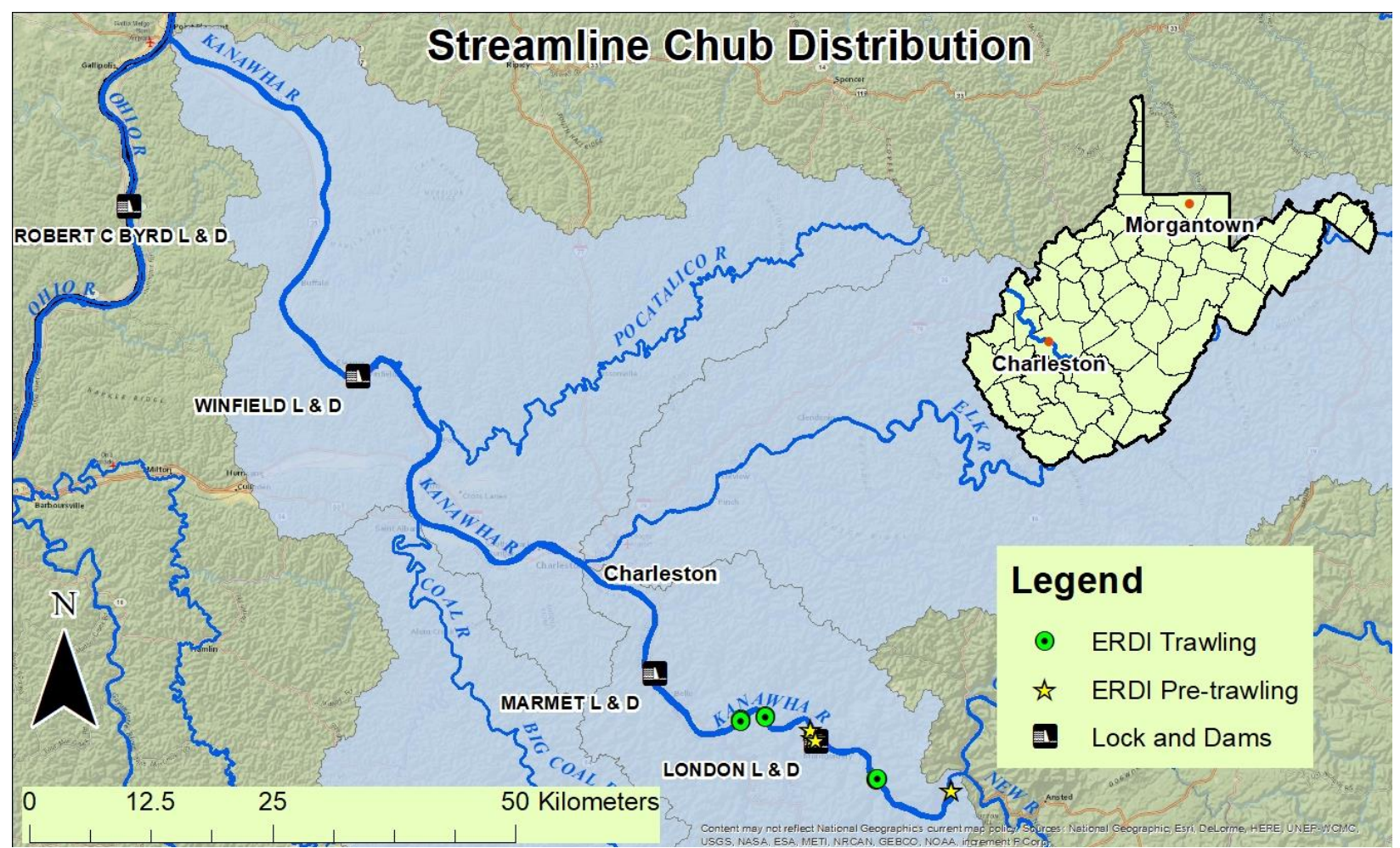

Figure 1: Distribution of the Streamline Chub (Erimystax dissimilis) in the Kanawha River, West Virginia.

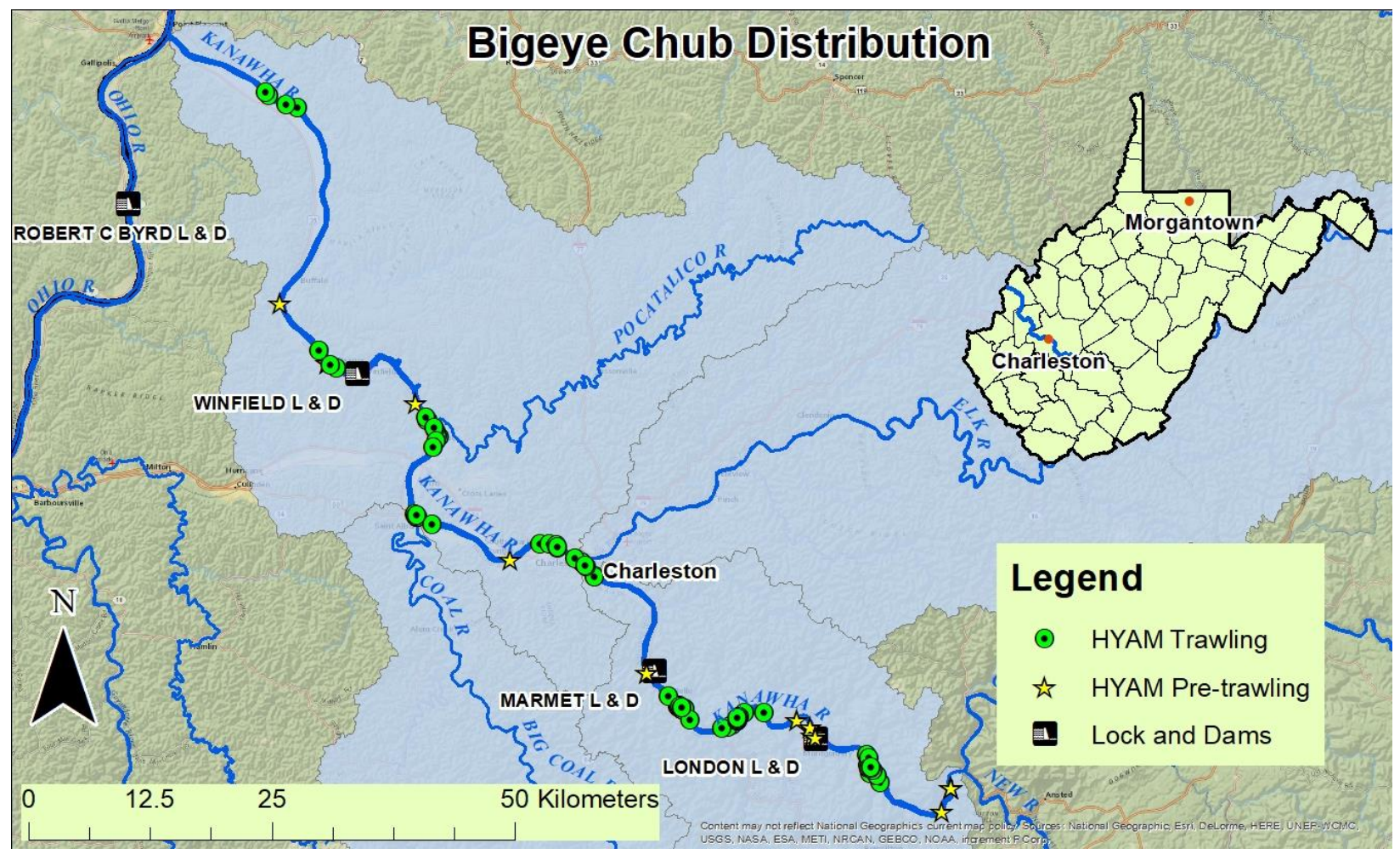

Figure 2: Distribution of the Bigeye Chub (Hybopsis amblops) in the Kanawha River, West Virginia. 


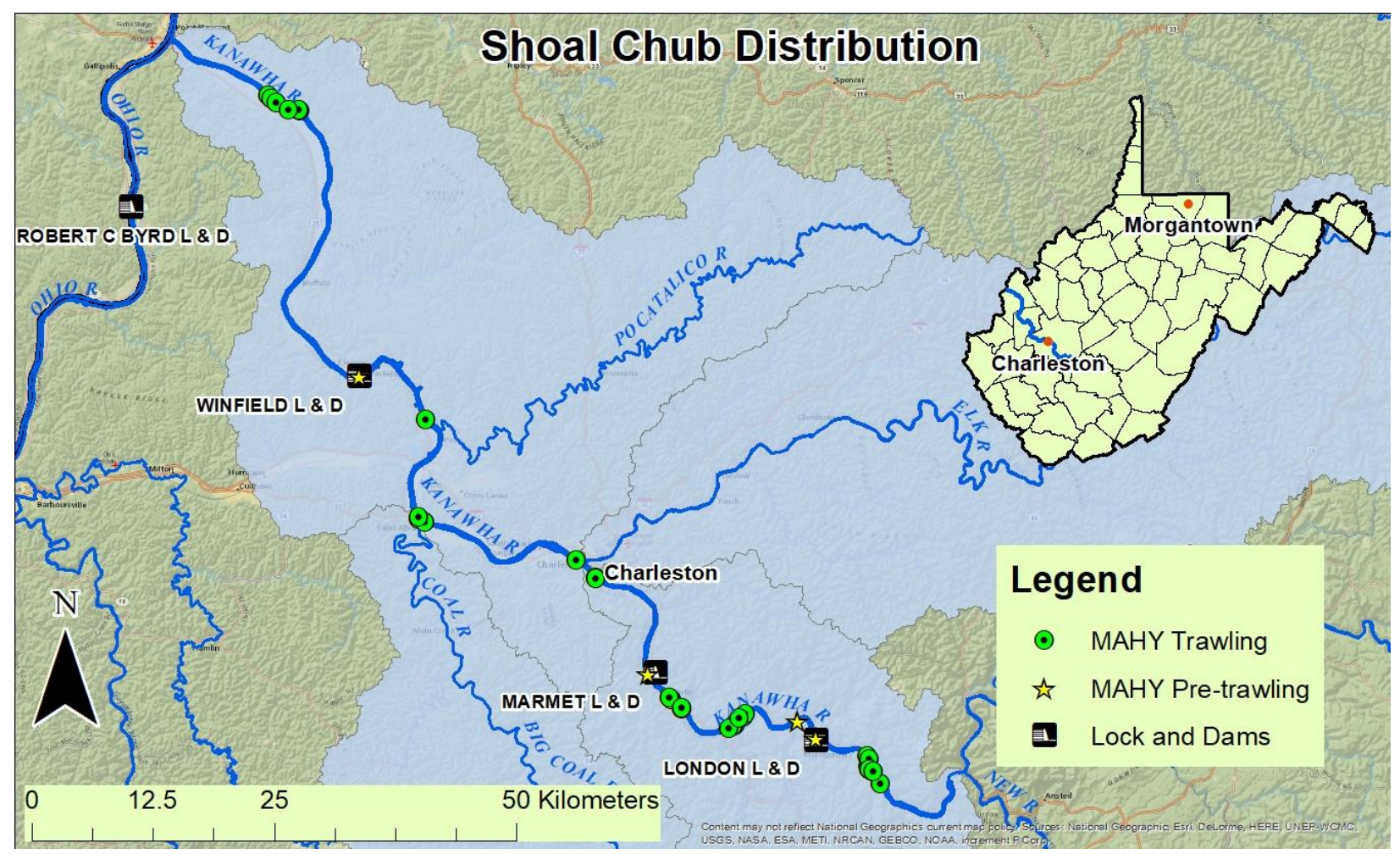

Figure 3: Distribution of the Shoal Chub (Macrhybopsis hyostoma) in the Kanawha River, West Virginia.

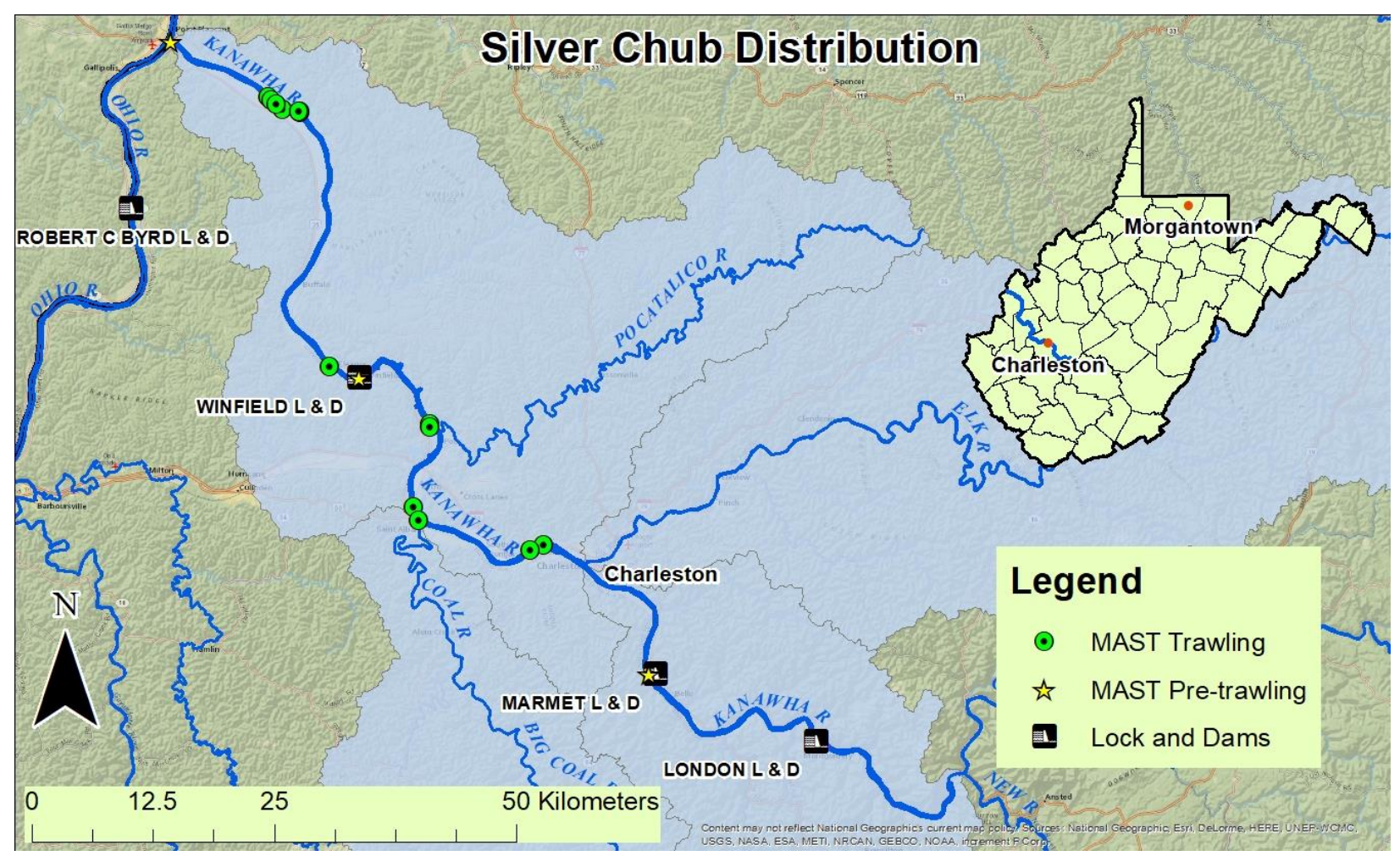

Figure 4:Distribution of the Silver Chub (Macrhybopsis storeriana) in the Kanawha River, West Virginia. 


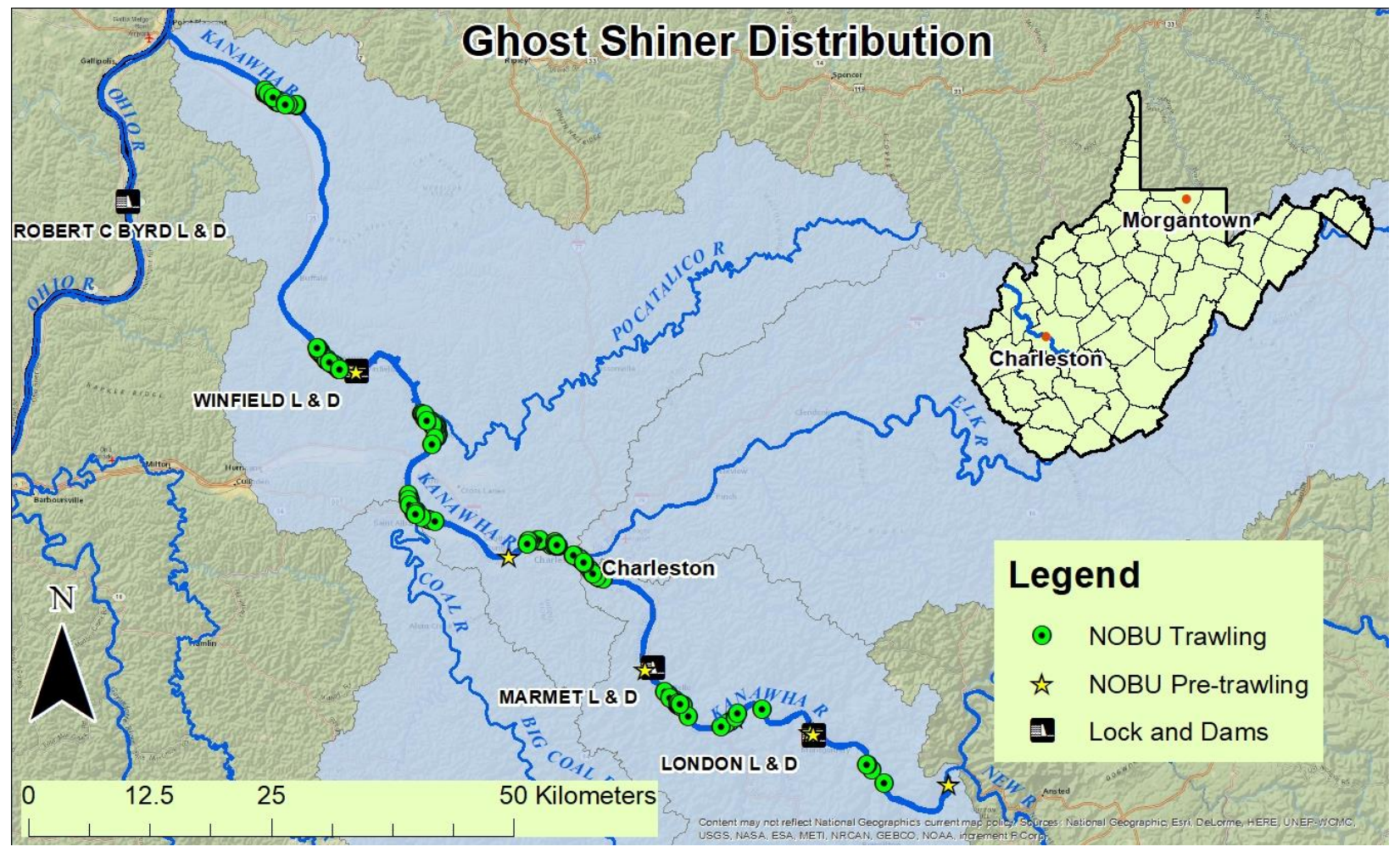

Figure 5: Distribution of the Ghost Shiner (Notropis buchanani) in the Kanawha River, West Virginia.

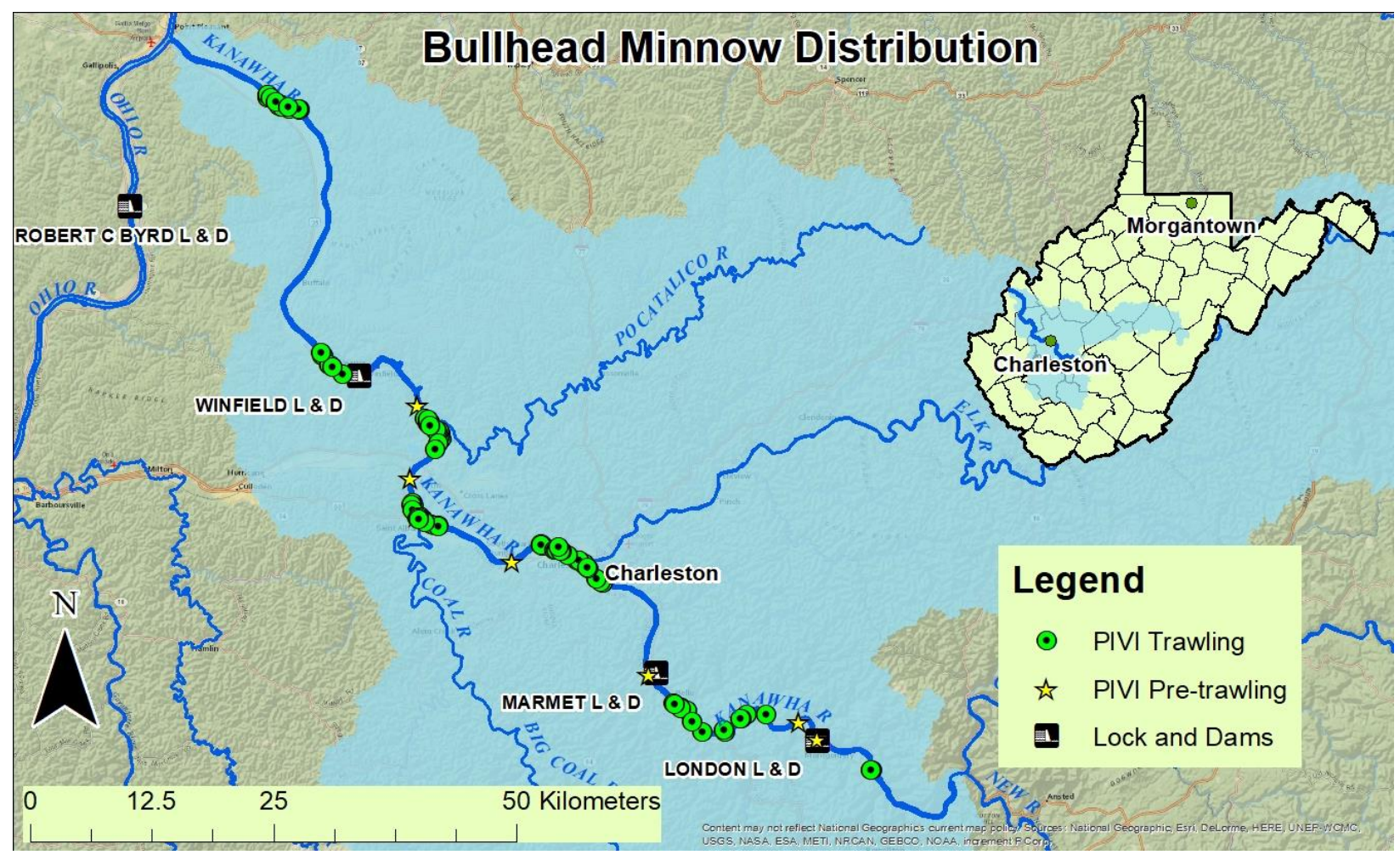

Figure 6: Distribution of the Bullhead Minnow (Pimephales vigilax) in the Kanawha River, West Virginia. 


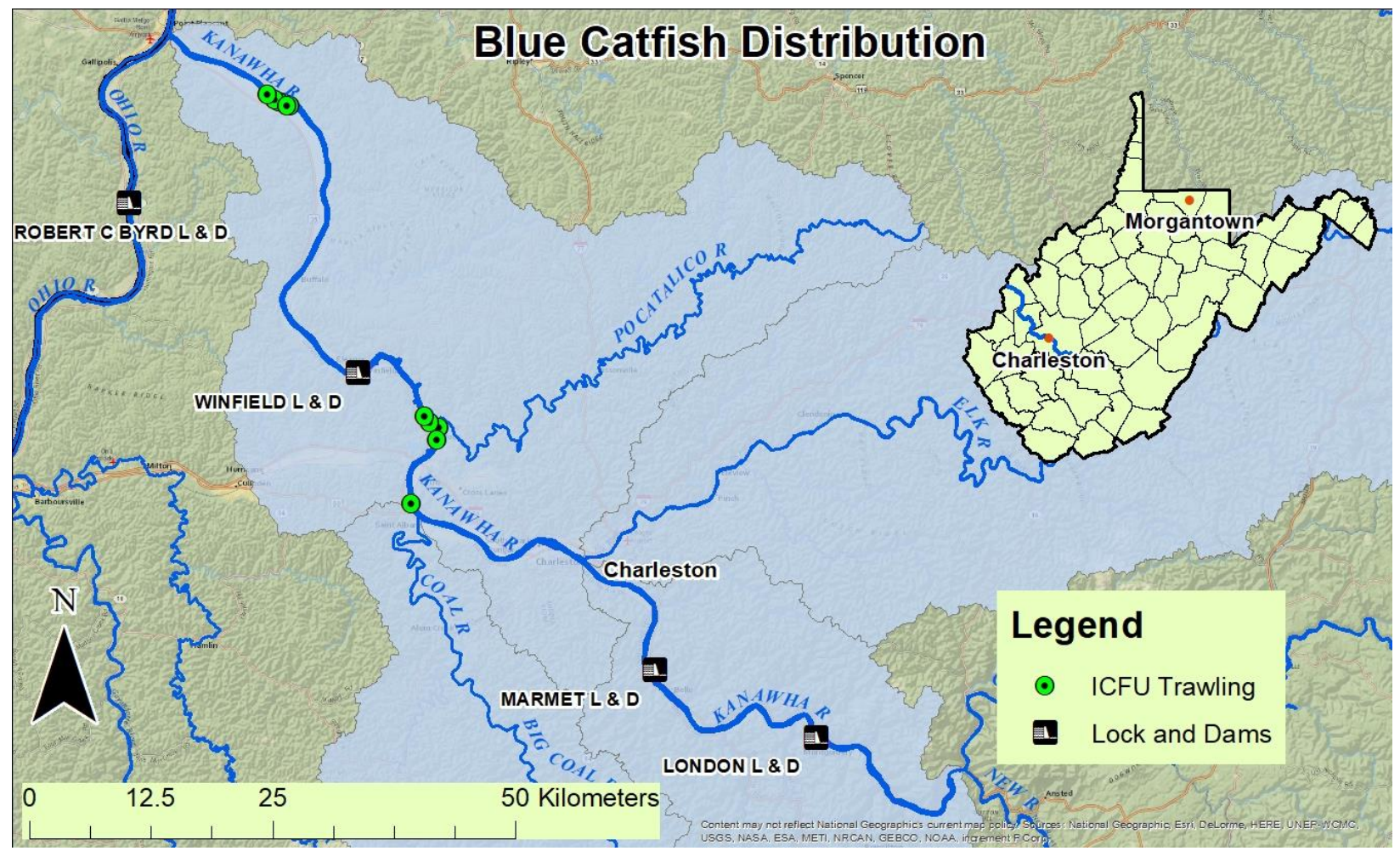

Figure 7:Distribution of the Blue Catfish (Ictalurus furcatus) in the Kanawha River, West Virginia.

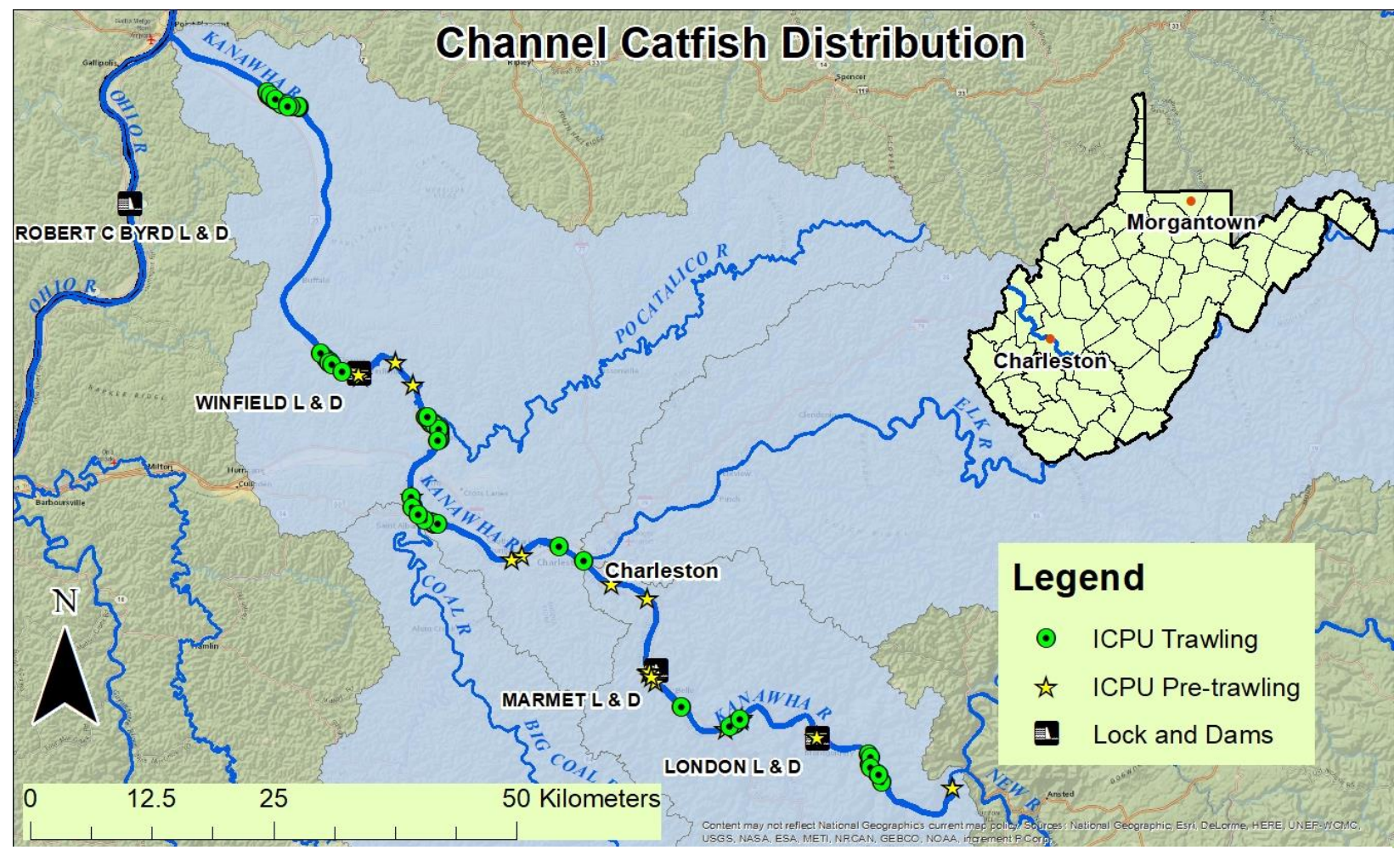

Figure 8:Distribution of the Channel Catfish (Ictalurus punctatus) in the Kanawha River, West Virginia. 


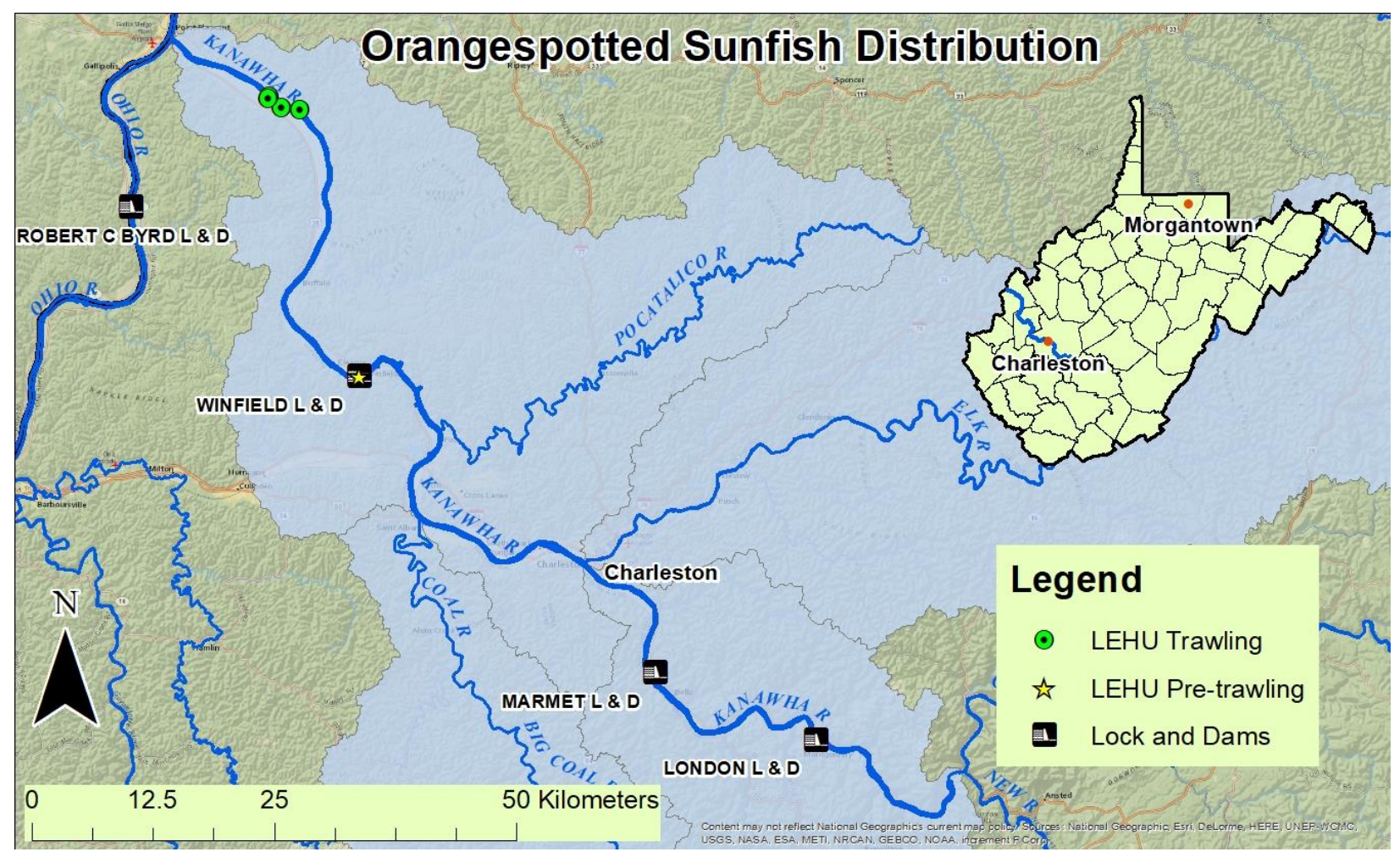

Figure 9: Distribution of the Orangespotted Sunfish (Lepomis humilis) in the Kanawha River, West Virginia.

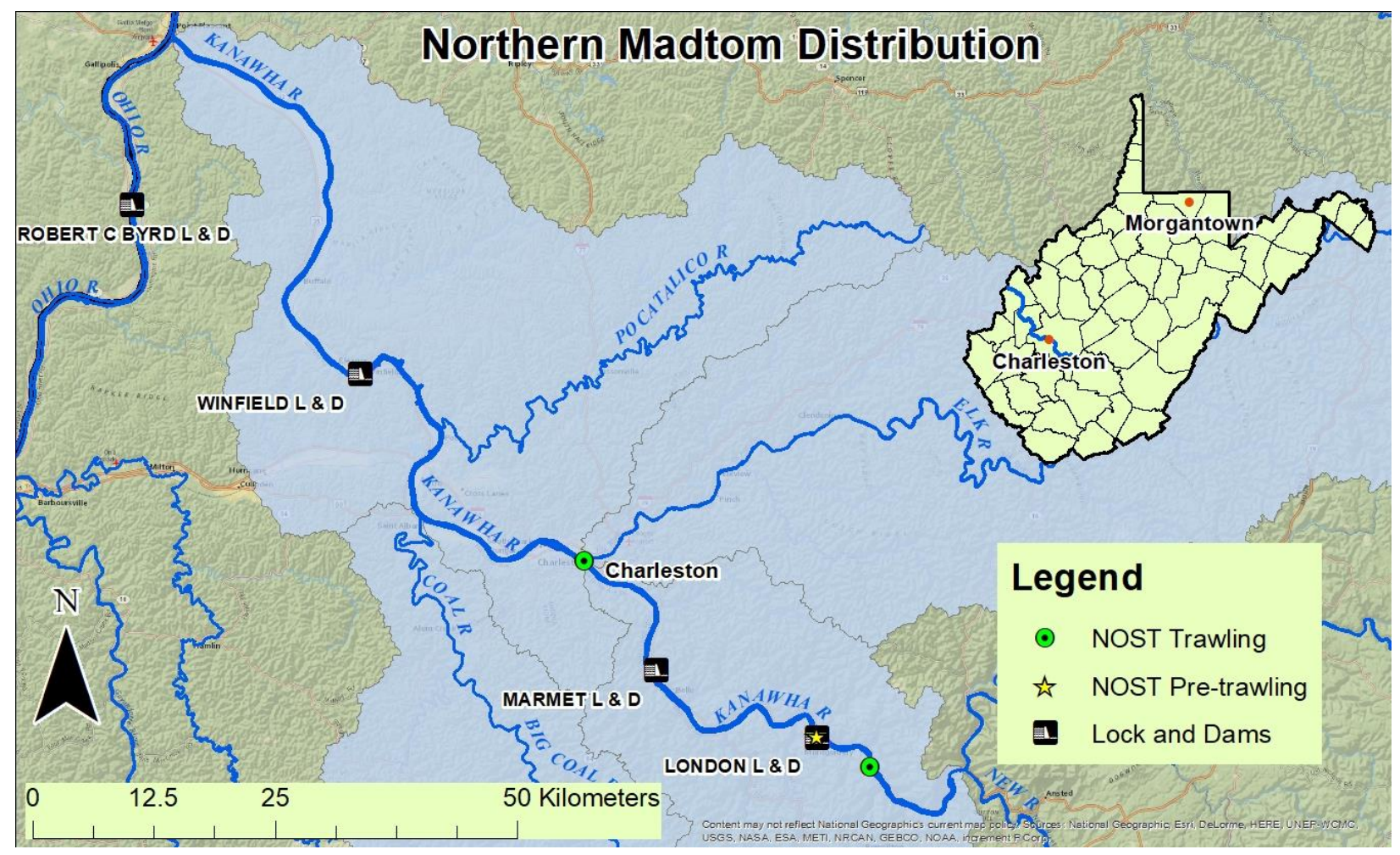

Figure 10: Distribution of the Northern Madtom (Noturus stigmosus) in the Kanawha River, West Virginia. 


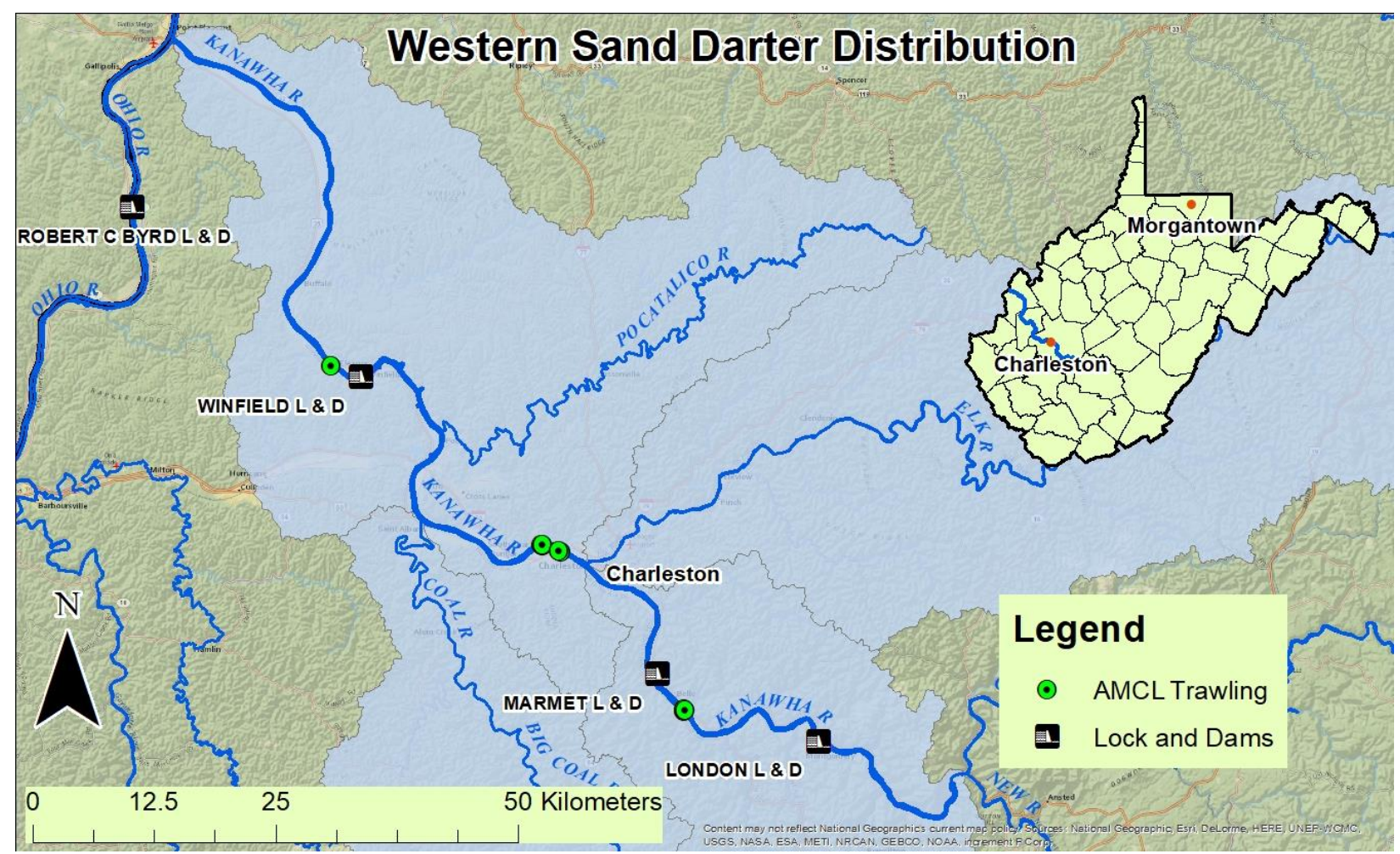

Figure 11: Distribution of the Western Sand Darter (Ammocrypta clara) in the Kanawha River, West Virginia.

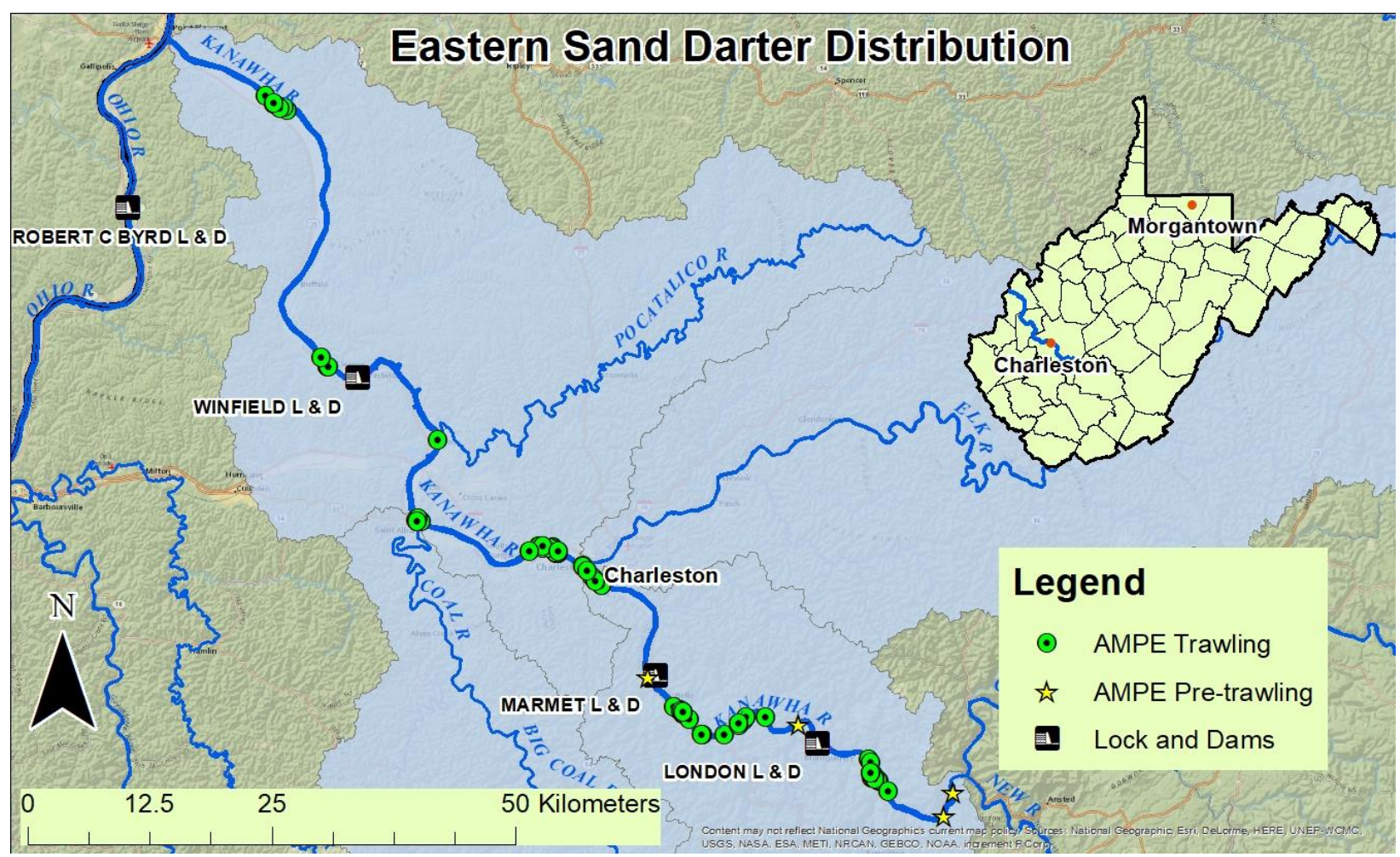

Figure 12: Distribution of the Eastern Sand Darter (Ammocrypta pellucida) in the Kanawha River, West Virginia. 


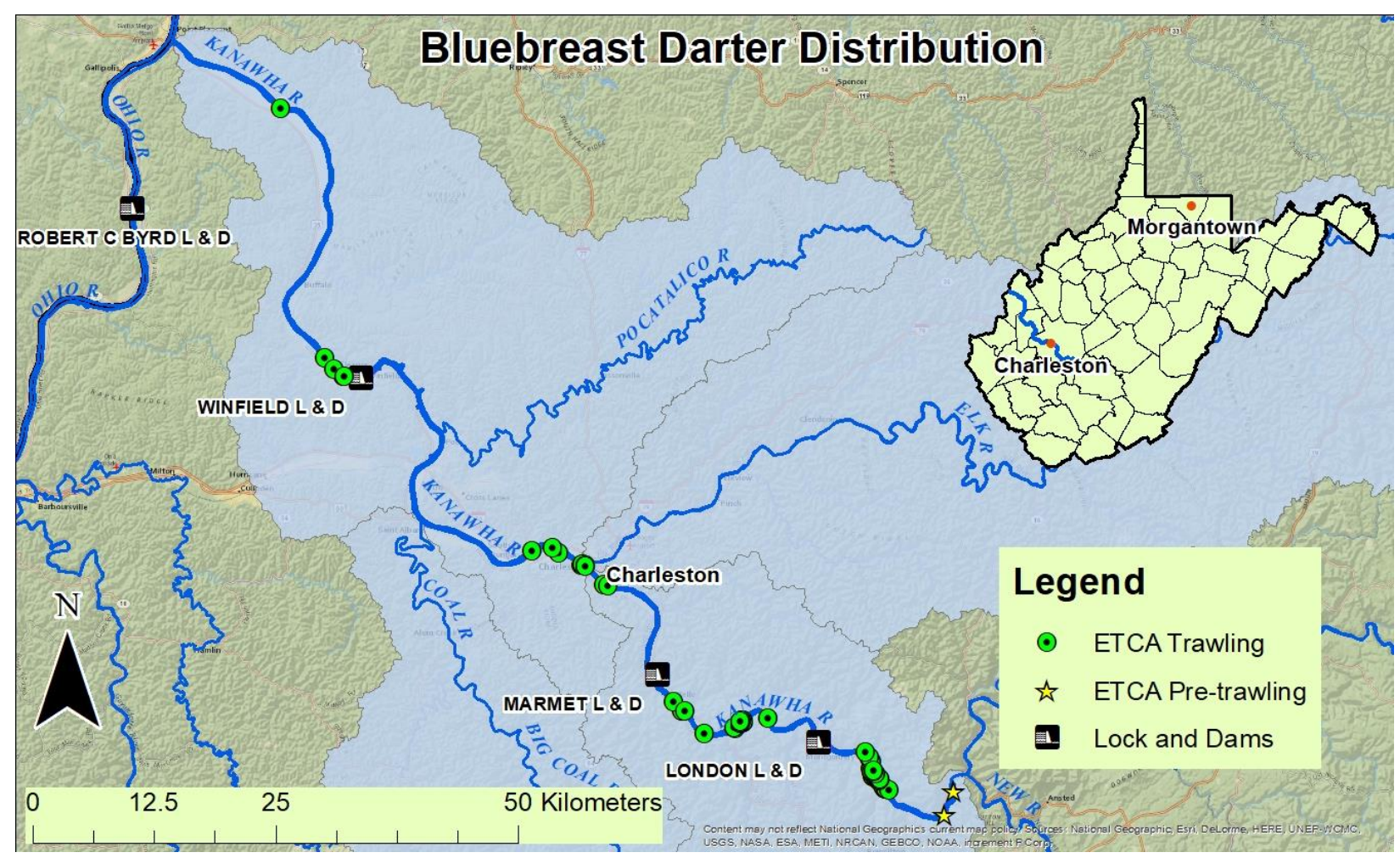

Figure 13: Distribution of the Bluebreast Darter (Etheostoma camurum) in the Kanawha River, West Virginia.

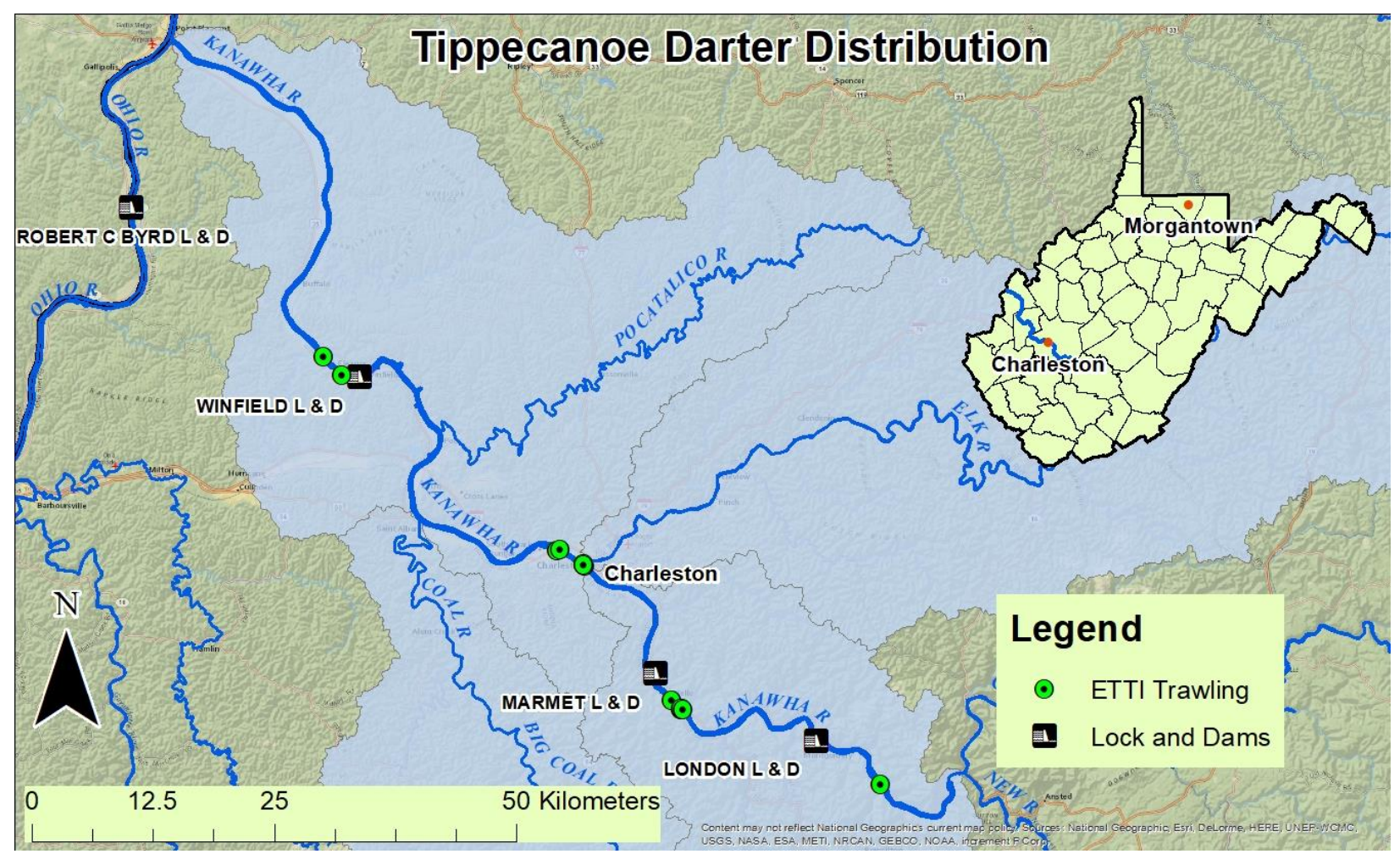

Figure 14: Distribution of the Tippecanoe Darter (Etheostoma tippecanoe) in the Kanawha River, West Virginia. 


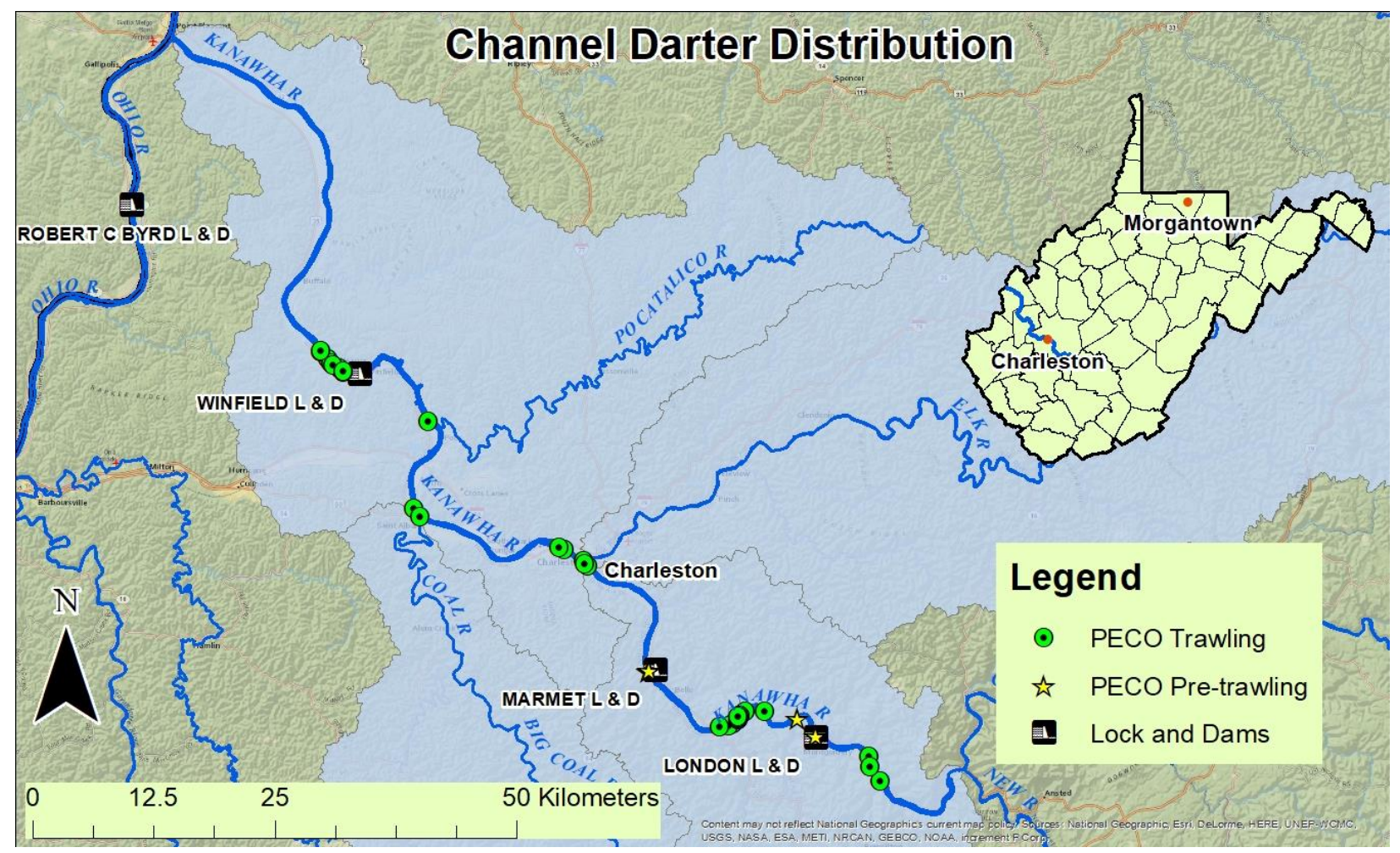

Figure 15: Distribution of the Channel Darter (Percina copelandi) in the Kanawha River, West Virginia.

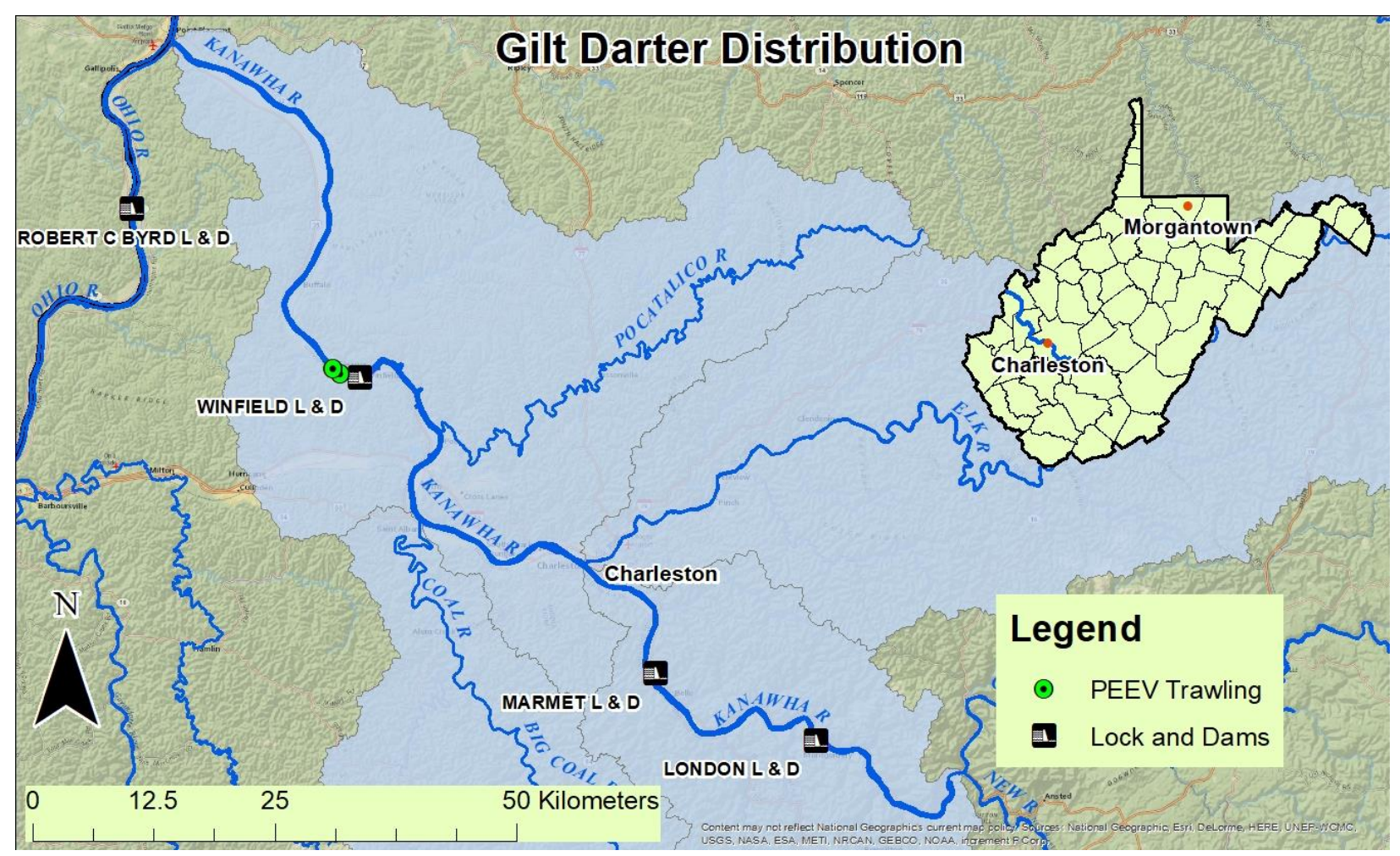

Figure 16: Distribution of the Gilt Darter (Percina evides) in the Kanawha River, West Virginia. 


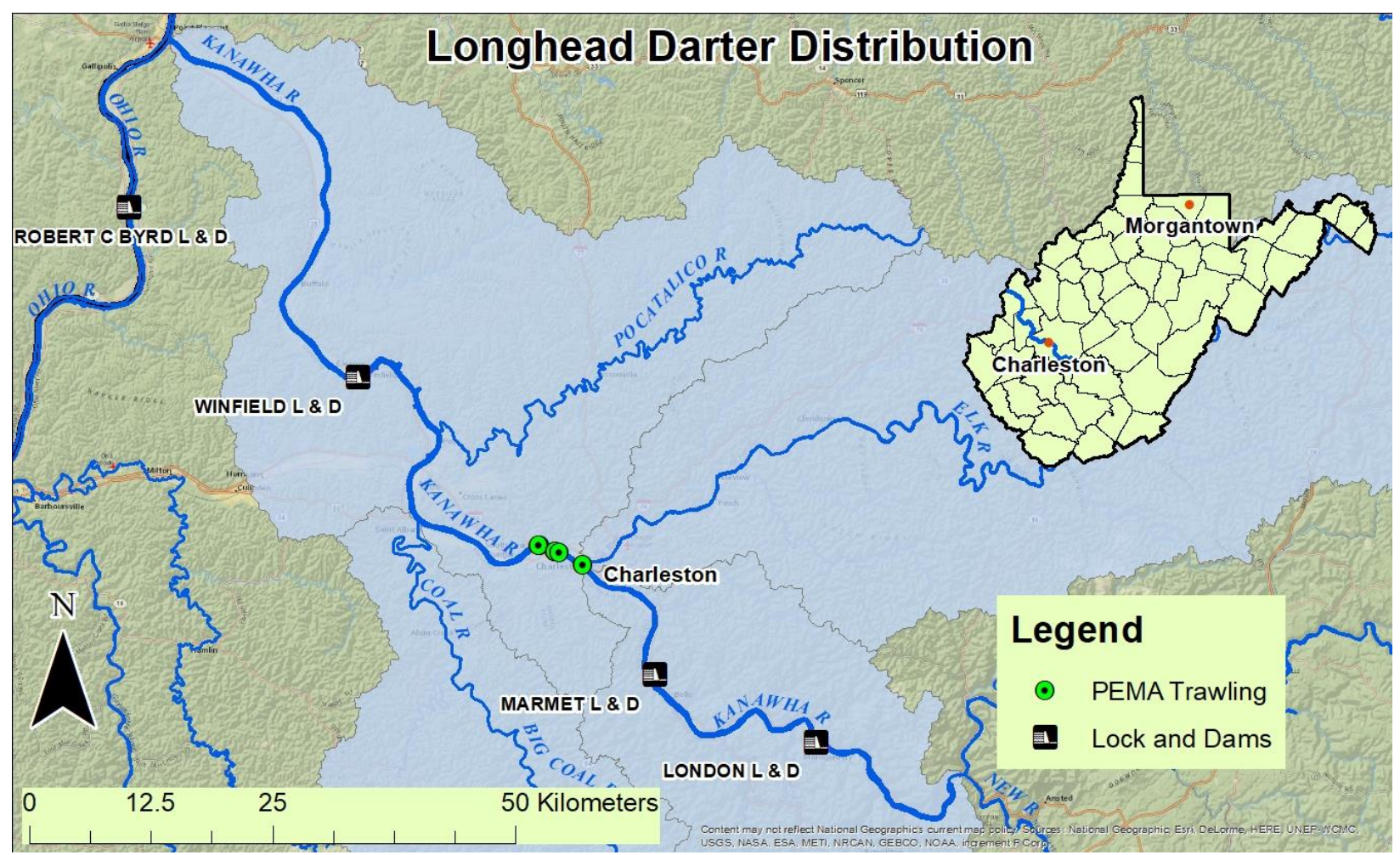

Figure 17: Distribution of the Longhead Darter (Percina macrocephala) in the Kanawha River, West Virginia.

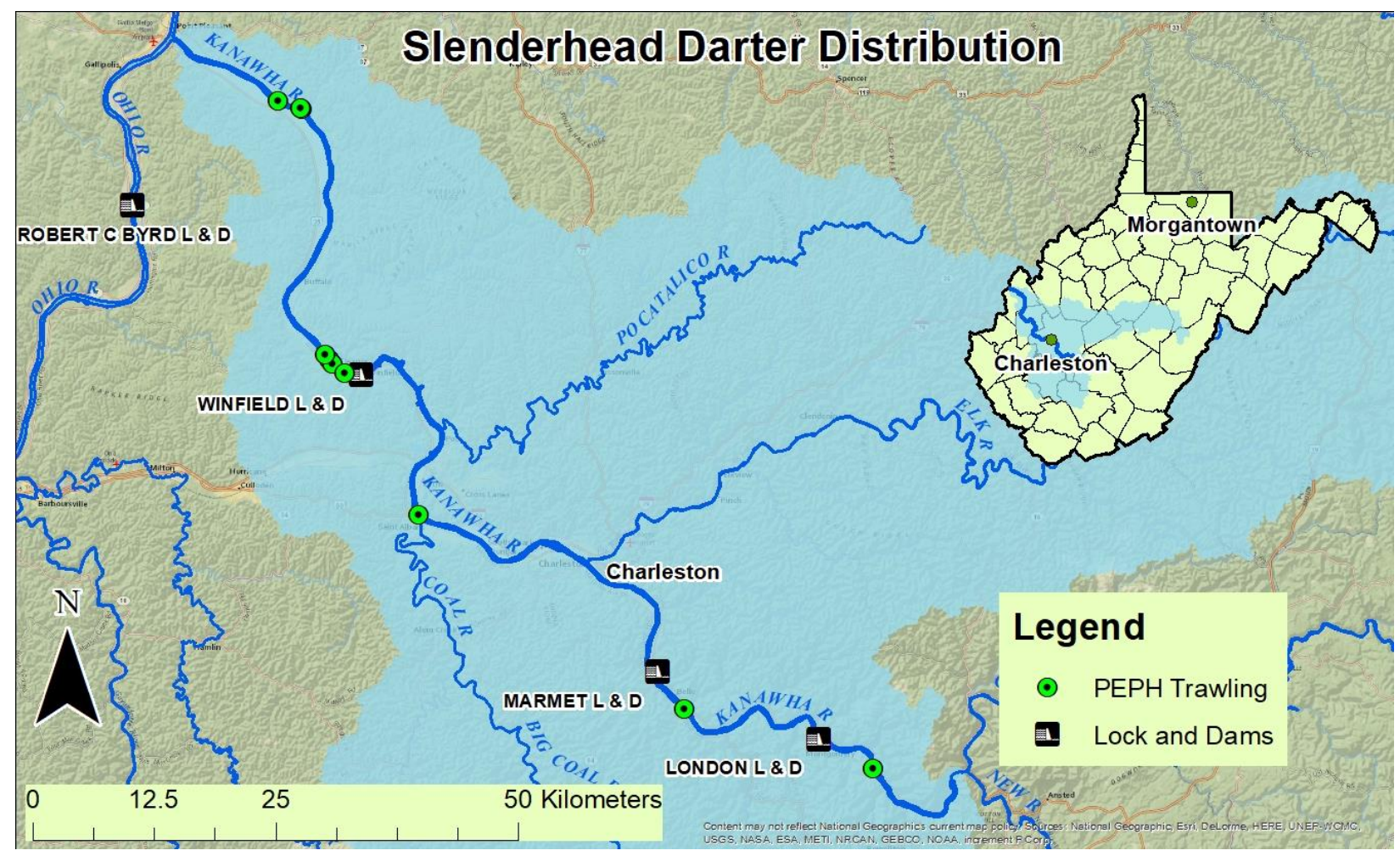

Figure 18: Distribution of the Slenderhead Darter (Percina phoxocephala) in the Kanawha River, West Virginia. 


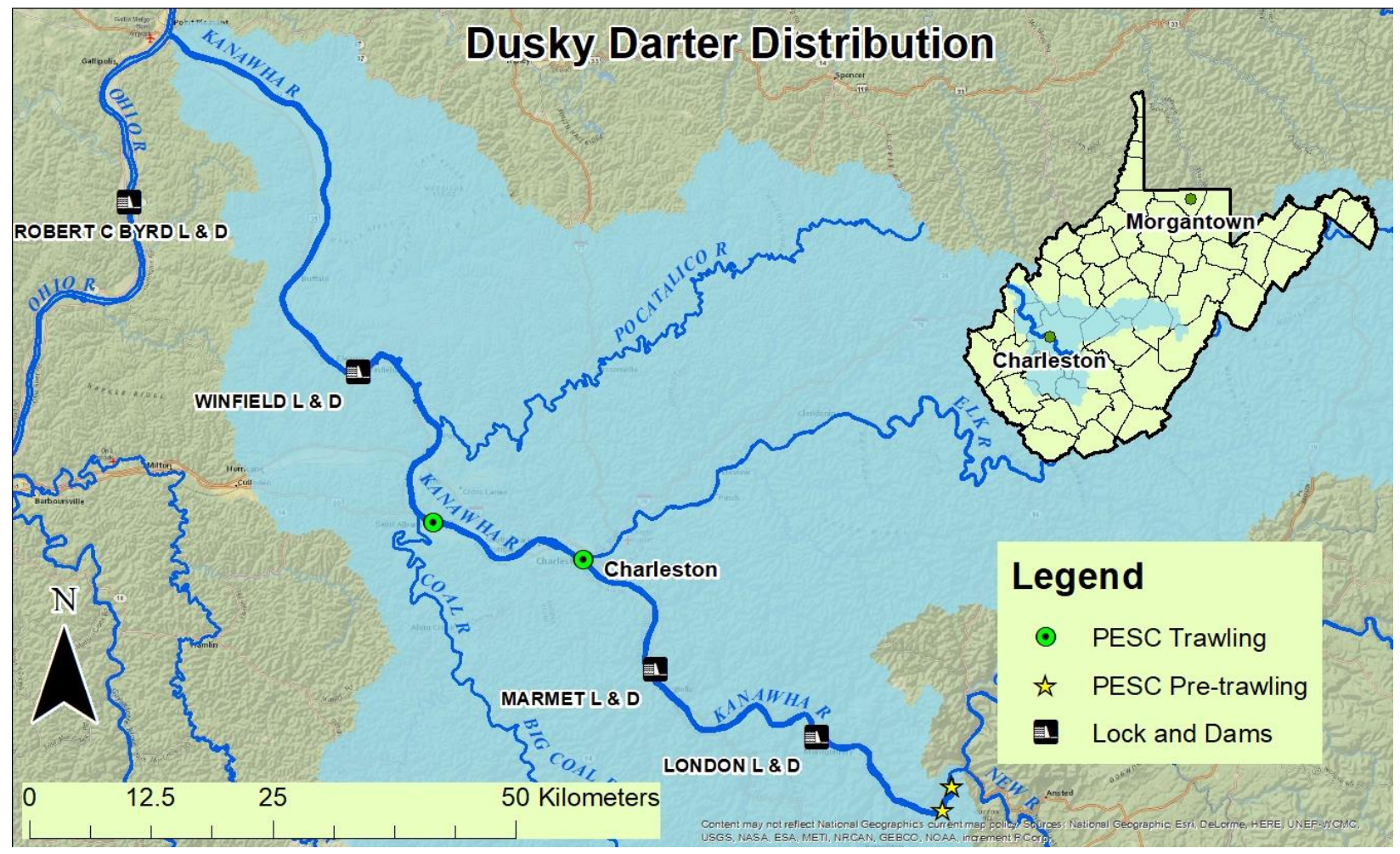

Figure 19: Distribution of the Dusky Darter (Percina sciera) (Swain) in the Kanawha River, West Virginia.

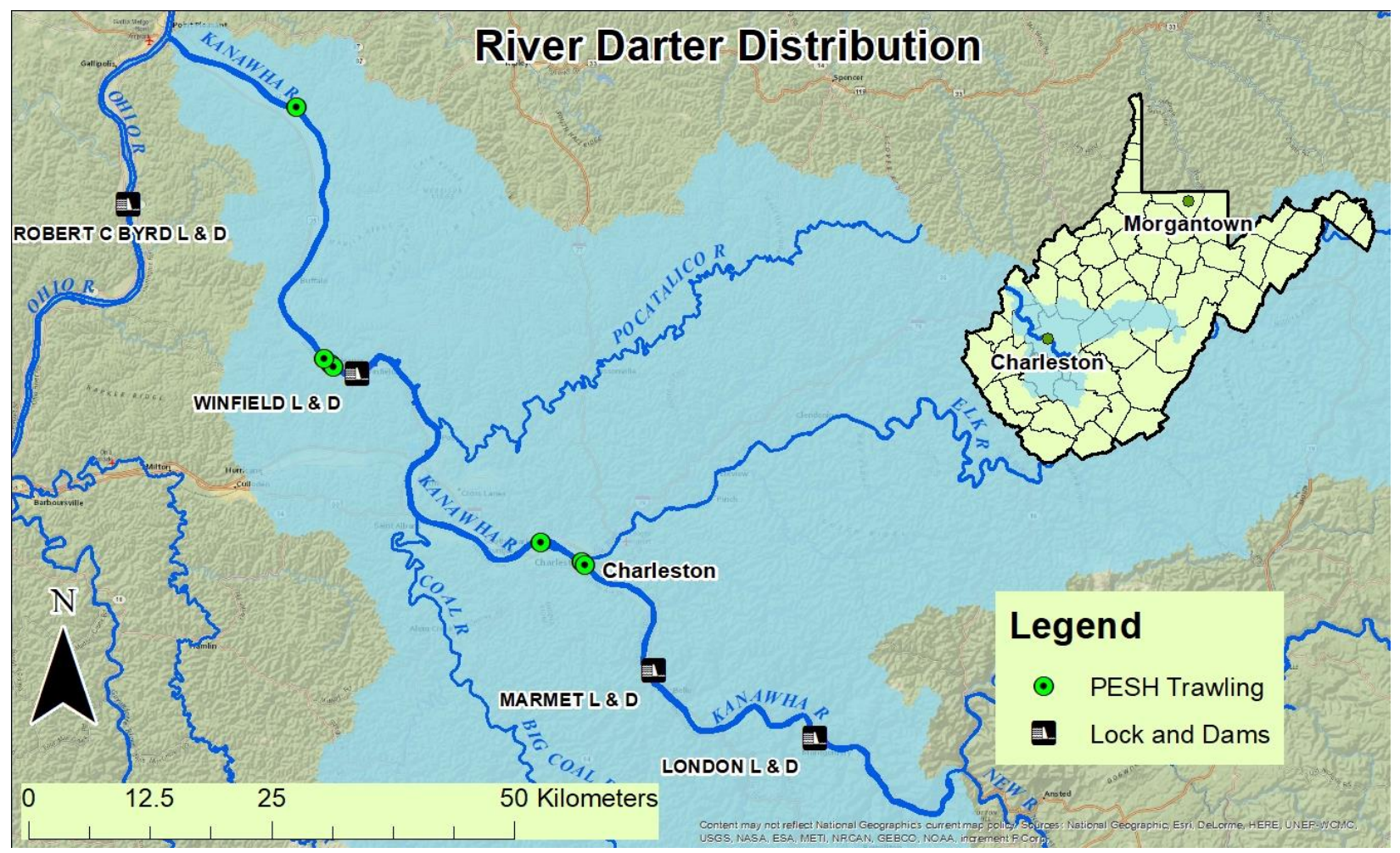

Figure 20: Distributing of the River Darter (Percina shumardi) in the Kanawha River, West Virginia. 